University of Windsor

Scholarship at UWindsor

\title{
Comparison of Austempering and Quench-and-Tempering Processes for Carburized Automotive Steels
}

\author{
Andrew Clark \\ University of Windsor
}

Follow this and additional works at: https://scholar.uwindsor.ca/etd

\begin{abstract}
Recommended Citation
Clark, Andrew, "Comparison of Austempering and Quench-and-Tempering Processes for Carburized Automotive Steels" (2013). Electronic Theses and Dissertations. 4919.

https://scholar.uwindsor.ca/etd/4919

This online database contains the full-text of PhD dissertations and Masters' theses of University of Windsor students from 1954 forward. These documents are made available for personal study and research purposes only, in accordance with the Canadian Copyright Act and the Creative Commons license-CC BY-NC-ND (Attribution, Non-Commercial, No Derivative Works). Under this license, works must always be attributed to the copyright holder (original author), cannot be used for any commercial purposes, and may not be altered. Any other use would require the permission of the copyright holder. Students may inquire about withdrawing their dissertation and/or thesis from this database. For additional inquiries, please contact the repository administrator via email (scholarship@uwindsor.ca) or by telephone at 519-253-3000ext. 3208.
\end{abstract}




\title{
Comparison of Austempering and Quench-and-Tempering Processes for Carburized Automotive Steels
}

\author{
by \\ Andrew Clark
}

\author{
A Thesis \\ Submitted to the Faculty of Graduate Studies \\ through Engineering Materials \\ in Partial Fulfilment of the Requirements for \\ the Degree of Master of Applied Science \\ at the University of Windsor
}

Windsor, Ontario, Canada

2013

(C) 2013 Andrew Clark 
Comparison of Austempering and Quench-and-Tempering

Processes for Carburized Automotive Steels

by

Andrew Clark

APPROVED BY:

Dr. W. Abdul-Kader

Department of Industrial and Manufacturing Systems Engineering

Dr. X. Sun

Chrysler LLC.

Dr. J. Sokolowski

Department of Mechanical, Automotive, and Materials Engineering

Dr. D.O. Northwood, Co-Advisor

Department of Mechanical, Automotive, and Materials Engineering

Dr. R.J. Bowers, Co-Advisor

Department of Mechanical, Automotive, and Materials Engineering

13 June 2013 


\section{DECLARATION OF CO-AUTHORSHIP / PREVIOUS PUBLICATION}

\section{Co-Authorship Declaration}

I hereby declare that this thesis incorporates material that is the result of joint research with Xichen Sun and Peter Bauerle of the Chrysler Headquarters and Test Center, Michigan USA, and Derek O. Northwood and Randy J. Bowers of the University of Windsor, Ontario. The research collaboration is covered in Chapter 4 of the thesis. In all cases, the key ideas, primary contributions, data analysis, and interpretation were performed by the author, and the contribution of co-authors was in the capacity of the research in the form of technical advice and suggestions.

I am aware of the University of Windsor Senate Policy on Authorship and I certify that I have properly acknowledged the contribution of other researchers to my thesis, and have obtained permission from each of the co-authors to include the above materials in my thesis.

I certify that, with the above qualification, this thesis, and the research to which it refers, is the product of my own work.

\section{Declaration of Previous Publication}

This thesis includes one original paper that has previously been published in peer reviewed conference proceedings, as follows:

\begin{tabular}{|l|l|l|}
\hline $\begin{array}{l}\text { Thesis } \\
\text { Chapter }\end{array}$ & Publication title/full citation & $\begin{array}{l}\text { Publication } \\
\text { status }\end{array}$ \\
\hline Chapter 3,4 & $\begin{array}{l}\text { Clark, A. D., D. O. Northwood, R. J. Bowers, X. } \\
\text { Sun, and P. Bauerle. "Comparison of } \\
\text { Austempering and Quench-and-Tempering } \\
\text { Processes for Carburized Automotive Steels." SAE } \\
\text { International Journal of Materials and } \\
\text { Manufacturing 6 (2) (2013): 146-153. }\end{array}$ & Published \\
\hline
\end{tabular}


I certify that I have obtained permission from the copyright owners to include the above published material in my thesis, and that the above material describes work completed during my registration as a graduate student at the University of Windsor.

I declare that, to the best of my knowledge, my thesis does not infringe upon anyone's copyright, nor violate any proprietary rights and that any ideas, techniques, quotations, or any other material from the work of other people included in my thesis, published or otherwise, are fully acknowledged in accordance with the standard referencing practices. To the extent that I have included copyrighted material that surpasses the bounds of fair dealing within the meaning of the Canada Copyright Act, I certify that I have obtained permission from the copyright owners to include such materials in my thesis.

I declare that this is a true copy of my thesis, including any final revisions, as approved by my thesis committee and the Graduate Studies office, and that this thesis has not been submitted for a higher degree to any other university or institution. 


\begin{abstract}
Austempering was examined as a replacement for the current quench-andtempering process as a method of heat treating carburized low alloy steel automotive components. Three carburizing grade steels, SAE 8620, 4320, and 8822, were carburized and heat treated by both processes. Twelve austempering and three quench-andtempering parameters were used. The effect of heat treatment on the case and core microstructures was examined. Distortion was characterized using Navy C-ring samples, which were measured before and after the carburizing and heat treatment process. X-ray diffraction was used to measure residual stress and retained austenite. Charpy impact and Rockwell C hardness testing were performed. Austempering produced improved distortion and residual stress characteristics over quench-and-tempering, while maintaining similar or improved mechanical properties. Full data sets for distortion and mechanical properties were developed. Wear and fatigue testing are identified as necessary next steps to fully examine the viability replacing the quench-and-tempering process with austempering.
\end{abstract}


This thesis is dedicated to

George Henry Clark 


\section{ACKNOWLEDGEMENTS}

First, I would like to thank my advisors Dr. Derek O. Northwood and Dr. Randy Bowers for their patience, support, and encouragement during the past two years. It is through their invaluable guidance that I was able to learn the skills I need to succeed in the workplace.

I would also like to thank Dr. Xichen Sun and Peter Bauerle from Chrysler LLC, who provided both technical suggestions and coordinated the testing which took place at the Chrysler Headquarters and Technology Center in Auburn Hills, Michigan. Special thanks are also extended to Proto Manufacturing Ltd. in Oldcastle, Ontario, whose X-ray diffraction services were generously provided.

Graciously acknowledged is the financial support of the Natural Sciences and Engineering Research Council of Canada (NSERC) and the Ontario College-University Consortium Council. 
TABLE OF CONTENTS

DECLARATION OF CO-AUTHORSHIP / PREVIOUS PUBLICATION ............... iii ABSTRACT .........................................................................................................................................v

DEDICATION.....................................................................................................

ACKNOWLEDGEMENTS.............................................................................................vii

LIST OF TABLES..............................................................................................................

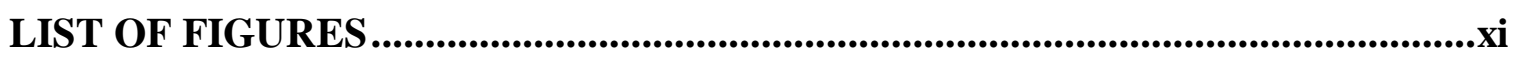

LIST OF ABBREVIATIONS.............................................................................. xiii

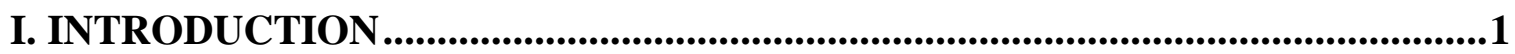

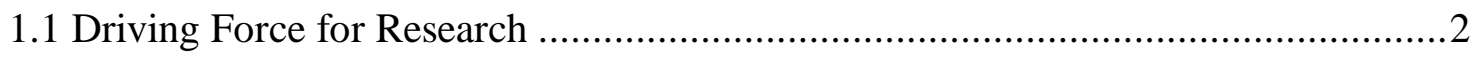

II. LITERATURE REVIEW ......................................................................................3

2.1 Steel Microstructure ....................................................................................

2.2 Alloying Effect on the TTT Curve............................................................... 10

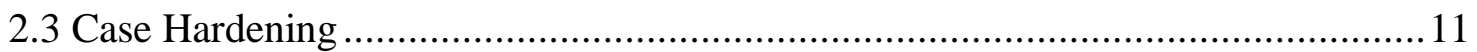

2.4 Heat Treatment Processes........................................................................... 12

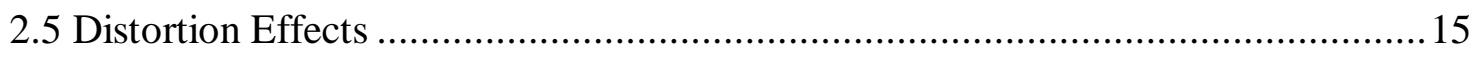

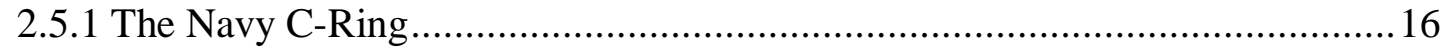

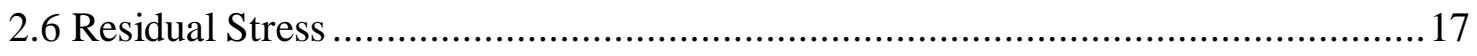

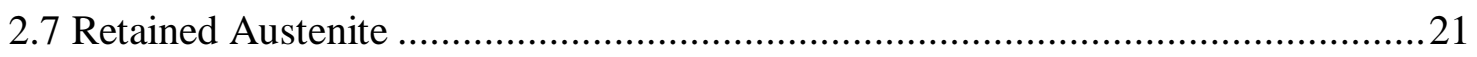

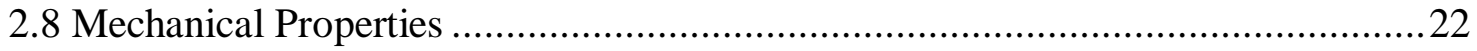

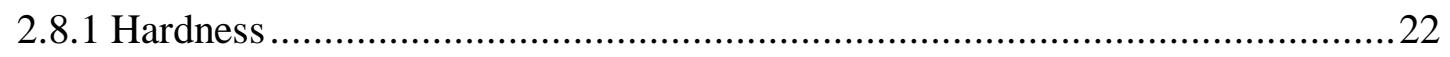

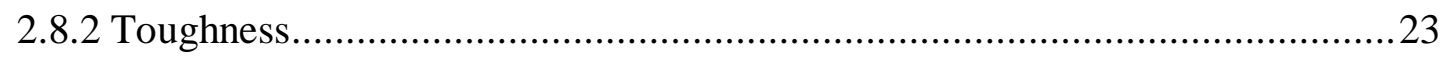

III. EXPERIMENTAL DETAILS ...............................................................................24

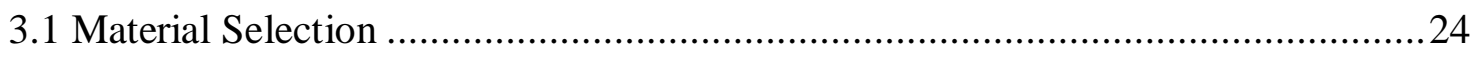

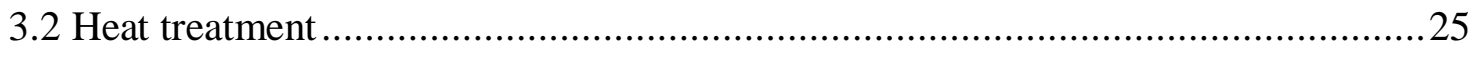

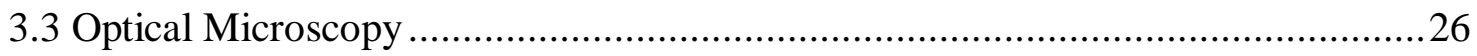

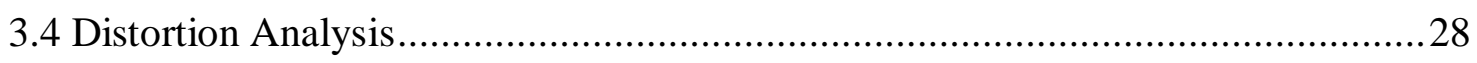

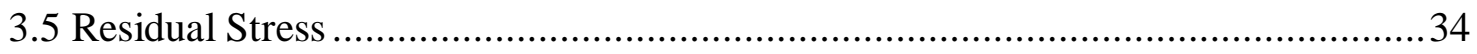

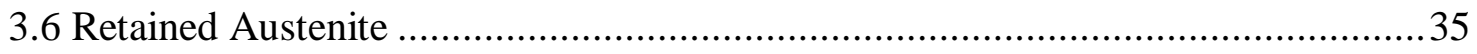

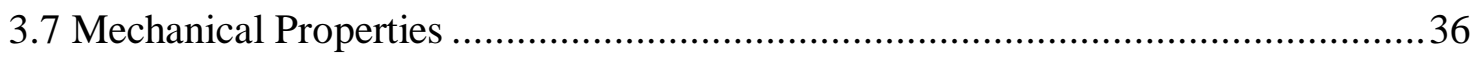




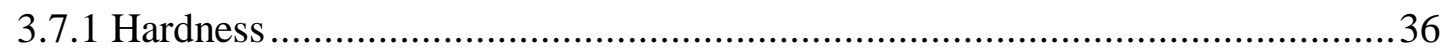

3.7.2 Charpy Impact Testing ...............................................................................

IV. RESULTS \& DISCUSSION.....................................................................................38

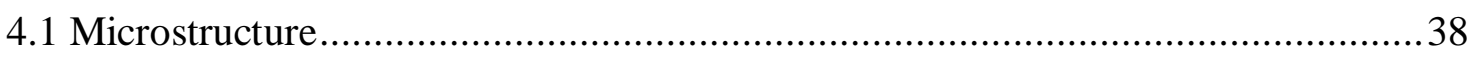

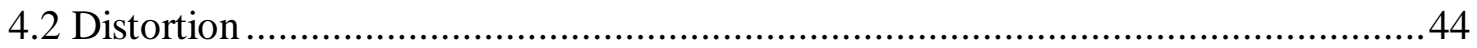

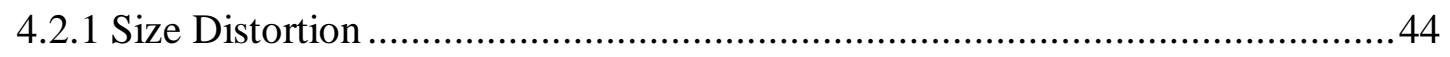

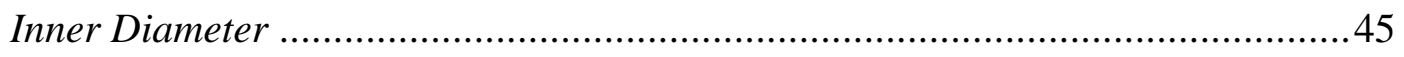

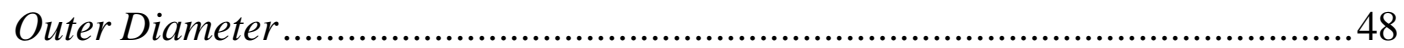

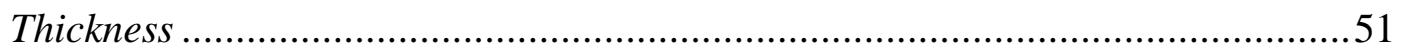

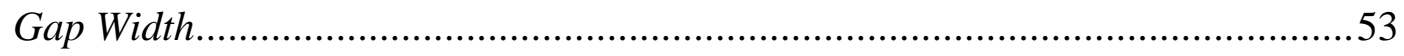

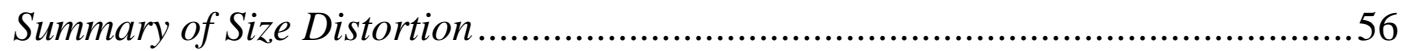

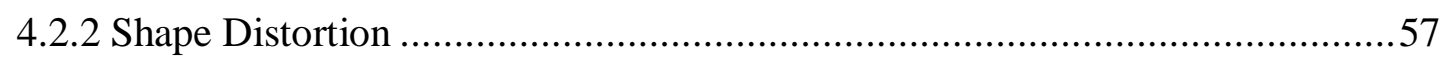

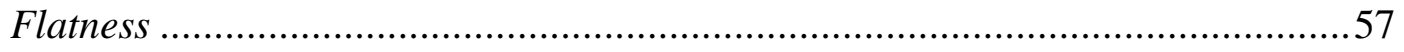

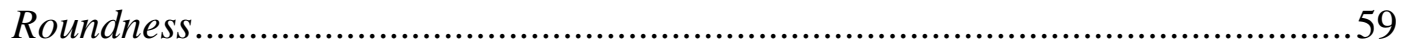

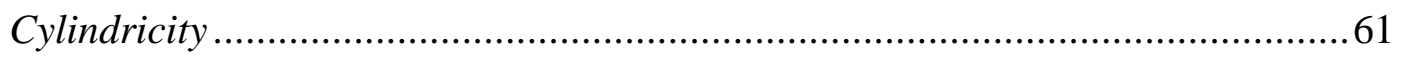

Summary of Shape Distortion .......................................................................62

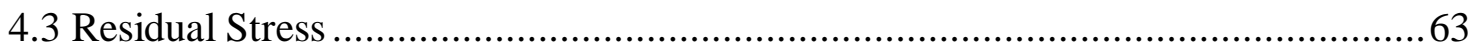

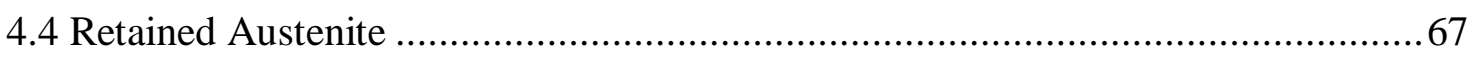

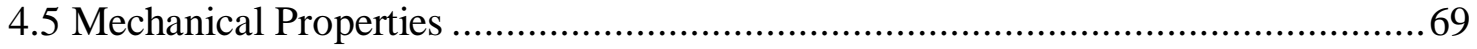

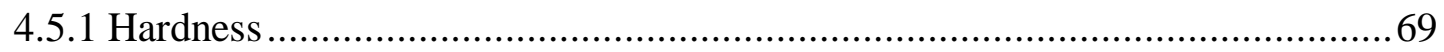

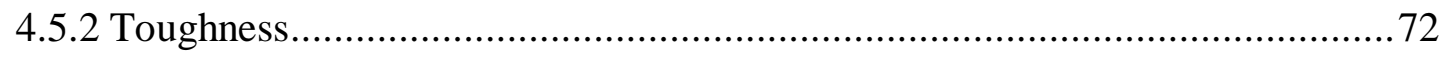

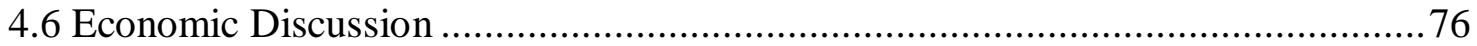

V. CONCLUSIONS AND RECOMMENDATIONS FOR FUTURE WORK ...........77

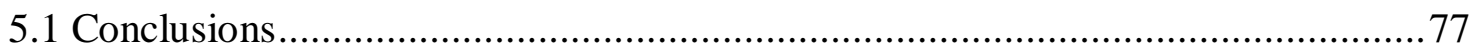

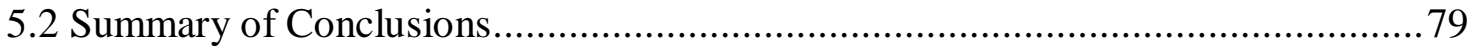

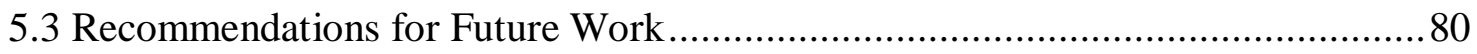

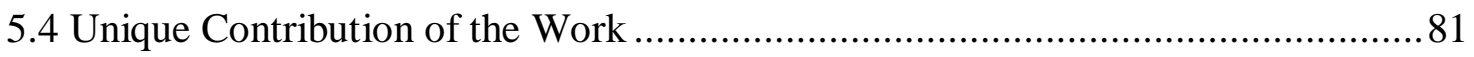

REFERENCES …...............................................................................................................8

PUBLICATIONS AND PRESENTATIONS ..........................................................88

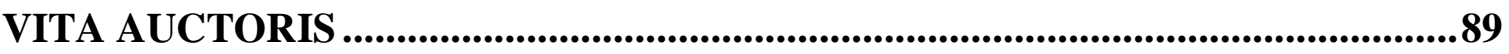




\section{LIST OF TABLES}

Table 2.1 - Volume change associated with phase transformations [39]. ...................... 17

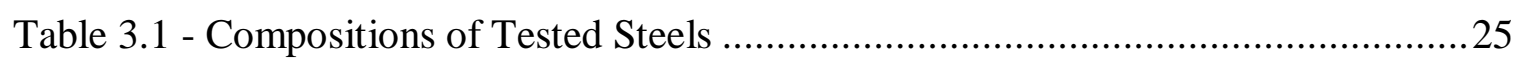

Table 3.2 - Initial Heat Treatment Conditions .......................................................26

Table 3.3 - Heat Treatment Parameters Selected for Further Study.............................27

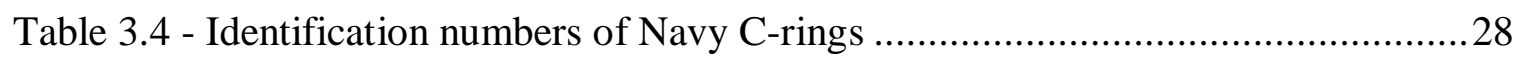

Table 3.5 - Residual Stress Measurement Depths for 4320 Steel .................................35

Table 3.6 - Retained Austenite Measurement Depths for 4320 Steel .............................36

Table 4.1 - Inner Diameter Distortion for 8620 Steel.......................................... 46

Table 4.2 - Outer Distortion for 8620 Steel ................................................... 49

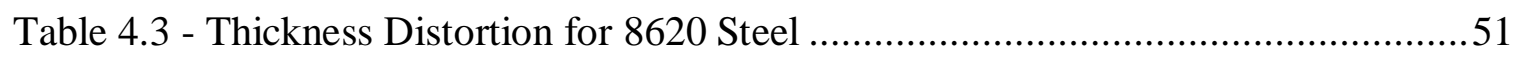

Table 4.4 - Gap Width Distortion for 8620 Steel ...................................................54

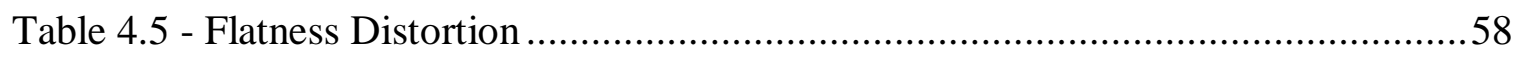

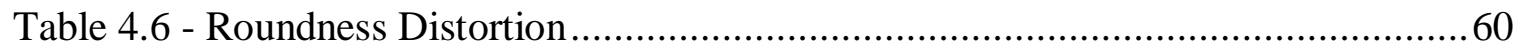

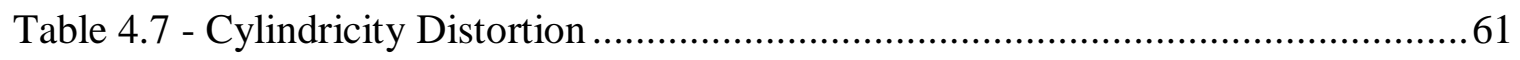

Table 4.8 - Surface Residual Stress Results for 4320 Steel ....................................64

Table 4.9 - Residual Stress Depth Measurements for 4320 Steel .............................6 65

Table 4.10 - Retained Austenite Measurement ....................................................... 68

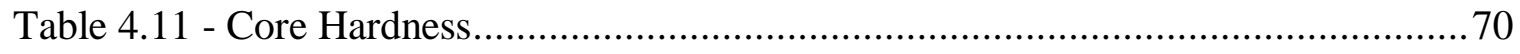

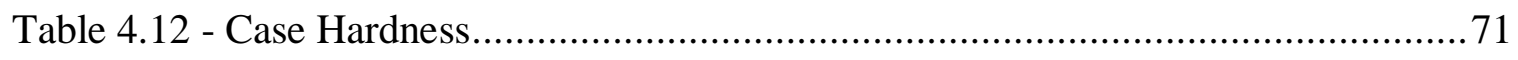

Table 4.13 - Charpy Impact Toughness for 8620 Steel ............................................ 72 


\section{LIST OF FIGURES}

Figure 2.1: The Iron-Carbon Phase Diagram [3] ......................................................

Figure 2.2: (A) Coarse pearlite and (B) Fine pearlite. [4] ............................................

Figure 2.3: TTT Curve for a eutectoid steel [4] ...................................................6

Figure 2.4: Martensite formed in core of 4320 steel carburized and austempered at

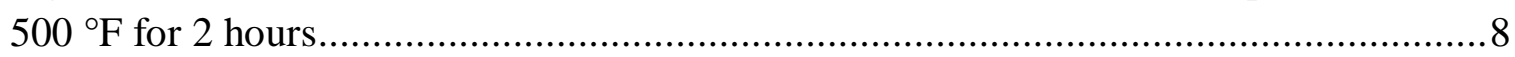

Figure 2.5: (A) Lower bainite, with a needle like appearance. (B) Upper bainite,

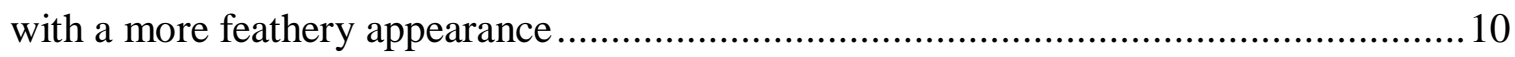

Figure 2.6: TTT curve for 4340 steel showing the bainite shelf [4] .............................11

Figure 2.7: Quench-and-temper process on a TTT curve [4]. .......................................13

Figure 2.8: TTT Curve showing three austempering heat treatments to produce

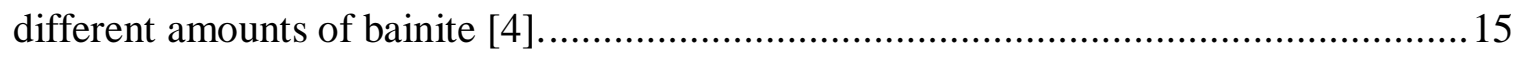

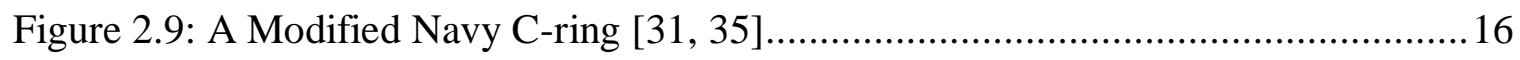

Figure 2.10: Typical residual stress depth profile found in carburized steel.

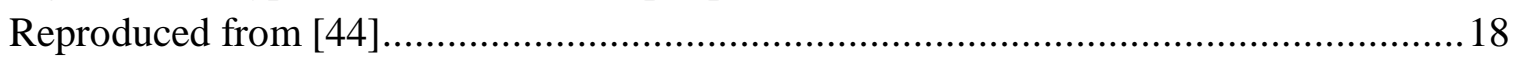

Figure 2.11: Bragg's law demonstrated visually [52].................................................19

Figure 2.12: Axes and Directions Used in X-Ray Diffraction [40, 53]........................21

Figure 3.1: 4320 steel carburized then austempered at $500{ }^{\circ} \mathrm{F}$ for (A) 30 minutes

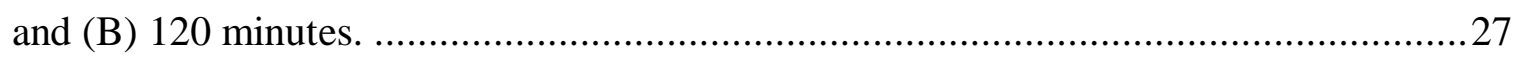

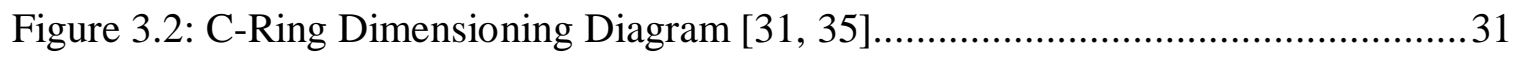

Figure 3.3: Flatness Test Plot Produced by CMM ......................................................... 32

Figure 3.4: Inner Cylindricity Test Plot Produced by CMM .............................................32

Figure 3.5: Roundness Test Plot Produced by CMM.................................................... 33

Figure 3.6: C-Ring positioned for surface residual stress measurement (left) and

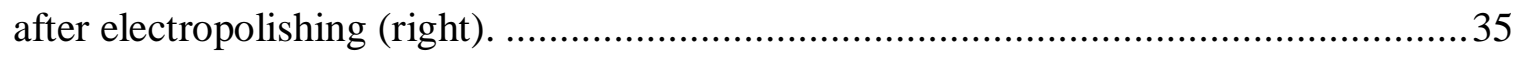

Figure 3.7: Dimensions of Type A Charpy Test Specimen from ASTM E23 [61]. ..........37 
Figure 4.1: Austempered 8620 steel case microstructures.

Figure 4.2: Austempered 4320 steel case microstructures.

Figure 4.3: Austempered 8822 steel case microstructures 42

Figure 4.4: Case and core microstructures for 4320 steel.

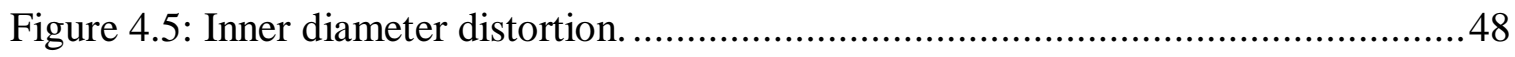

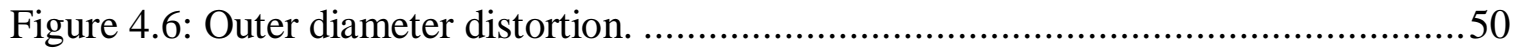

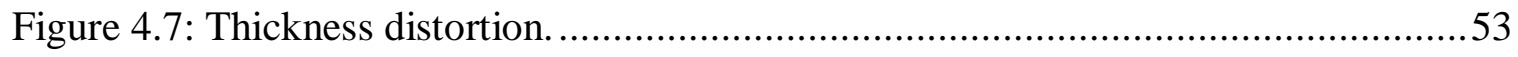

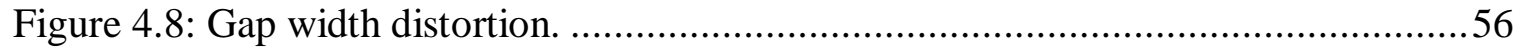

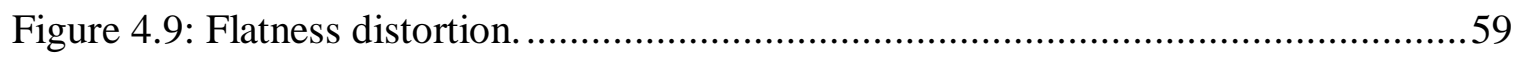

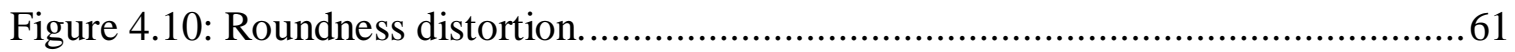

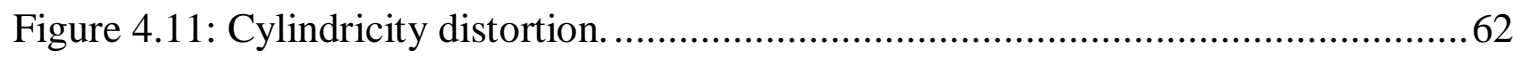

Figure 4.12: Surface residual stress for 4320 steel...............................................64

Figure 4.13: Surface residual stress and outer diameter distortion. ...........................65

Figure 4.14: Residual stress and depth for austempered and quench-and-tempered

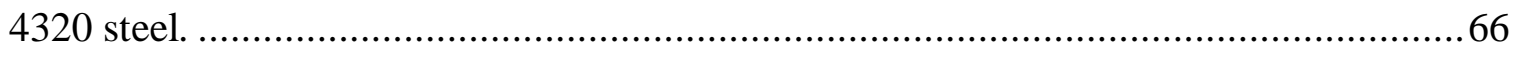

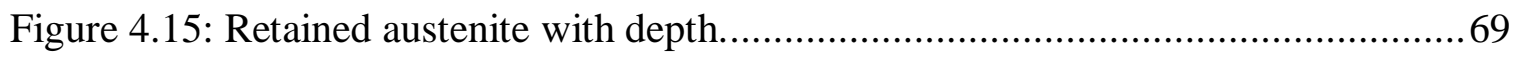

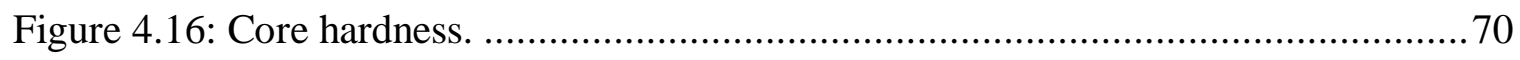

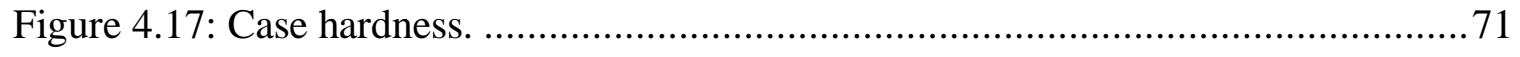

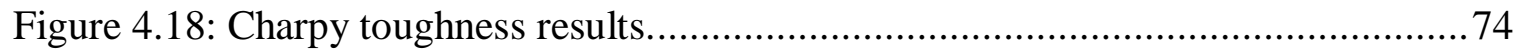

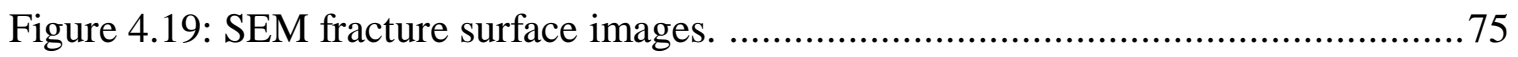




\section{LIST OF ABBREVIATIONS}

NSERC Natural Sciences and Engineering Research Council of Canada

SAE Society of Automotive Engineers

CMM Coordinate Measurement Machine

TTT Time-Temperature Transformation

CCT Continuous Cooling Transformation

Q\&T Quench and Tempering

ASTM American Society for Testing and Materials

DBTT Ductile-to-Brittle Transformation Temperature

ID Inner Diameter

OD Outer Diameter

SEM Scanning Electron Microscope 


\section{INTRODUCTION}

Carburizing is a method of case-hardening low carbon steel to improve its wear and friction characteristics. In this process low carbon steel is placed in a high carbon atmosphere, or packed in a carbon rich material; the temperature is raised into the austenitic phase region; and carbon diffuses into the surface layer of the material. This carburized surface layer influences the microstructural transformations that occur upon cooling. Typically, carburized steels are quenched to room temperature, forming a hard, high carbon martensitic surface while maintaining a more ductile, low carbon content core. The steel is then commonly tempered at intermediate temperature to increase the toughness of the material.

Associated with the carburization and subsequent heat treatment processes, dimensional changes occur in the part due to both phase transformations, as well as thermal expansion and contraction. This distortion can cause parts to deviate from the desired dimensions, which necessitates corrective measures, and hence another step in the manufacturing process. Distortion is closely related to residual stresses, which are also formed during transformation and non-uniform cooling. Typically compressive residual stresses are formed in the case of carburized steel, which increase the fatigue life of a component.

In the present study, austempering was considered as a possible replacement for the quench-and-tempering of carburized steels. It has the potential to lower distortion, which could eliminate the costly reworking step associated with traditional quench-andtemper processes for carburized components. 


\subsection{Driving Force for Research}

The purpose of this research project was to examine the viability of austempering replacing quench-and-tempering as a method of producing carburized automotive parts. It examined three common carburizing-grade steels currently used for roller bearings, gears, and camshafts as well as the heat treatments used to produce them.

The effects of heat treatment on the case and core microstructures of carburized SAE 8620, 8822, and 4320 steels were examined. A total of 12 austempering and 3 quench-and-tempering conditions were examined. Hardness for both case and core were measured. Charpy V-notch testing was used to determine the toughness of the heat treated steels.

Navy C-rings were machined and heat treated to examine distortion, residual stress, and retained austenite levels during heat treatment. Distortion was measured using a coordinate measurement machine $(\mathrm{CMM})$. X-ray diffraction was used to measure the residual stress and retained austenite levels in the heat treated samples.

The ability to remove processing steps such as distortion correction and tempering provides an opportunity to reduce production cost for parts. For the austempering process to be considered, it would be necessary for the mechanical properties, distortion levels, and microstructural characteristics of the austempered conditions to be comparable to those found for the current quench-and-tempered process. 


\section{LITERATURE REVIEW}

The following literature review addresses the important aspects of this thesis topic. Included are discussions on microstructure, heat treatment, and mechanical properties of carburized heat treated steels, as well as a discussion of the austempering and quench-and-tempering processes. Distortion, residual stress, retained austenite, and the measurement of these factors, is also presented.

\subsection{Steel Microstructure}

Steel is a high strength iron-carbon alloy. It sees a wide variety of uses in the automotive industry, where it is used for panels, structural members and driveline parts [1]. The mechanical properties of steel can be affected by both its chemistry and the heat treatments which are applied during manufacturing. Figure 2.1 shows the iron-carbon phase diagram; where the weight percentage of carbon in the steel is on the horizontal axis, ranging from $0 \%$ to $6.67 \%$, while temperature on the vertical axis. Steels typically have below $1 \%$ carbon, although steels with higher carbon contents up to $2 \%$ do see use [2].

There are 4 phases which are shown on the phase diagram: $\alpha$-ferrite, bodycentered-cubic structured iron which has low solubility for carbon; $\delta$-ferrite, a high temperature ferrite phase which has slightly higher solubility for carbon; austenite, a face-centered-cubic structure that has much greater solubility carbon than ferrite; and cementite, an intermetallic compound which is 6.67 weight $\%$ carbon and 93.3 weight $\%$ iron. The eutectoid temperature, noted on the diagram at $727^{\circ} \mathrm{C}$, is the lowest temperature at which it is possible to maintain austenite. Heating above this temperature 
and holding will cause the steel microstructure to begin transform to austenite. The eutectoid temperature is associated with the eutectoid composition, 0.77 weight $\%$ carbon. Steels with greater than eutectoid carbon content are referred to as hyper-eutectoid, while those with less than eutectoid carbon content are hypo-eutectoid.

At equilibrium cooling rates, the austenite formed at high temperature will transform to $\alpha$ ferrite and cementite. For non-eutectoid steels, the austenite will begin to transform above the eutectoid temperature. A hyper-eutectoid steel will begin forming proeutectoid cementite during cooling, and will have a resultant structure of pearlite and cementite. Hypo-eutectoid steels will form pro-eutectoid ferrite, and result in a structure of ferrite and pearlite. As cooling rates increase the time for diffusion will decrease, resulting in finer pearlite, and because of this the hardness, toughness, and strength of the material will rise. Fine and coarse pearlite can be seen in Figure 2.2. With increased cooling rates there is a method to predict the resultant microstructure. Time-Temperature Transformation (TTT) curves and Continuous Cooling Transformation (CCT) curves show how holding at temperature and cooling rate can affect final microstructure. Figure 2.3 shows the TTT curve for eutectoid steel. The lines on the graph represent microstructural transformation points. There are start lines for the transformation to pearlite, bainite, and martensite, as well as lines which show when complete transformation of austenite to another phase can be expected. 


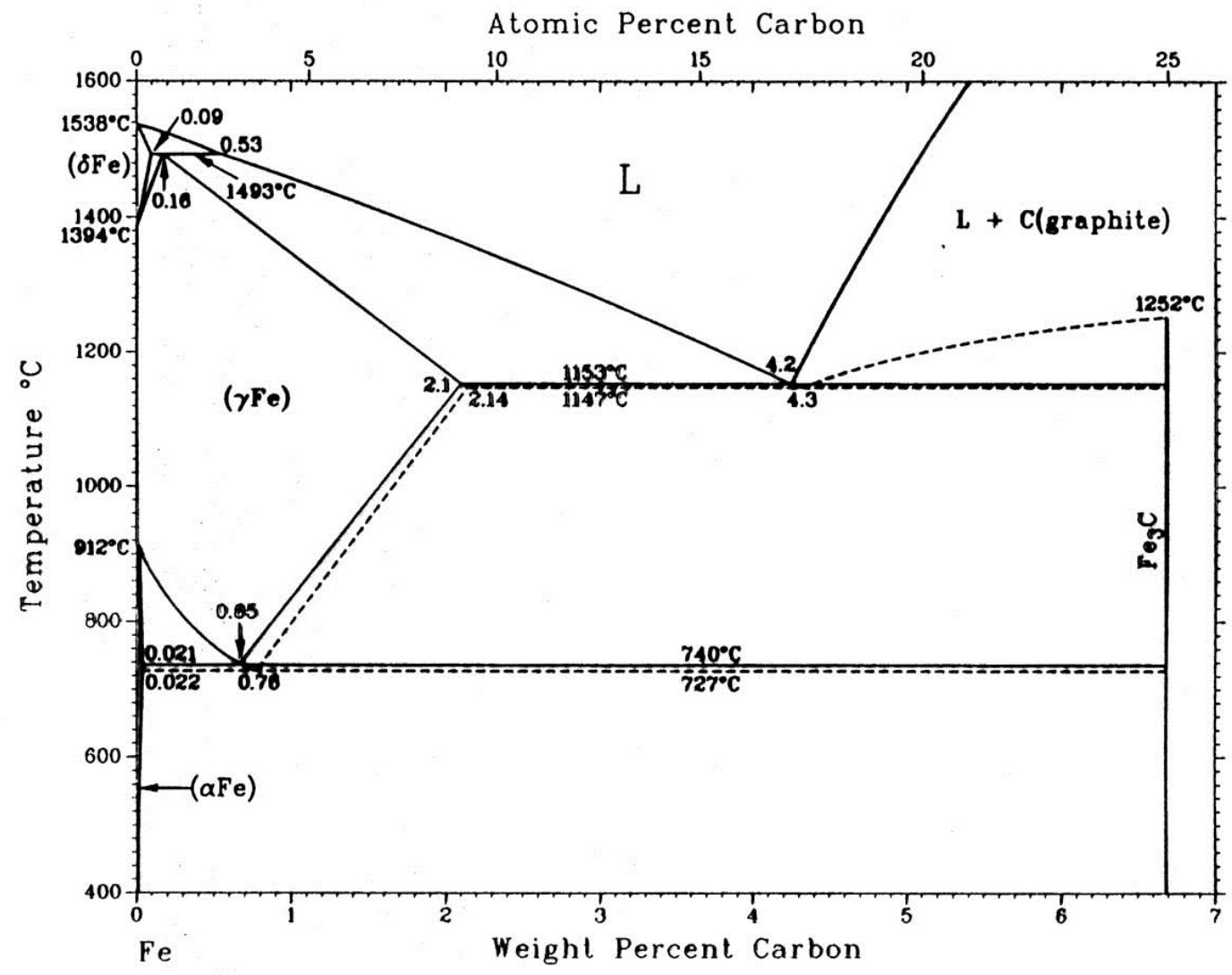

Figure 2.1: The Iron-Carbon Phase Diagram [3]. 

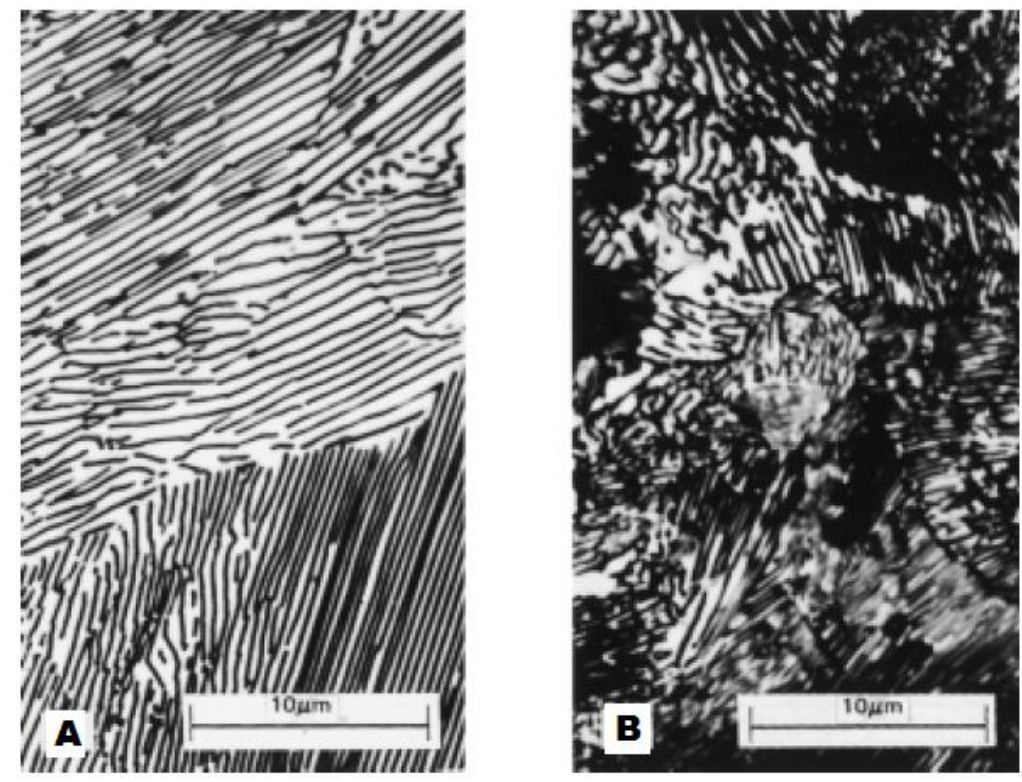

Figure 2.2: (A) Coarse pearlite and (B) Fine pearlite. The darker portions of the diagram are cementite, the lighter portions are ferrite [4].

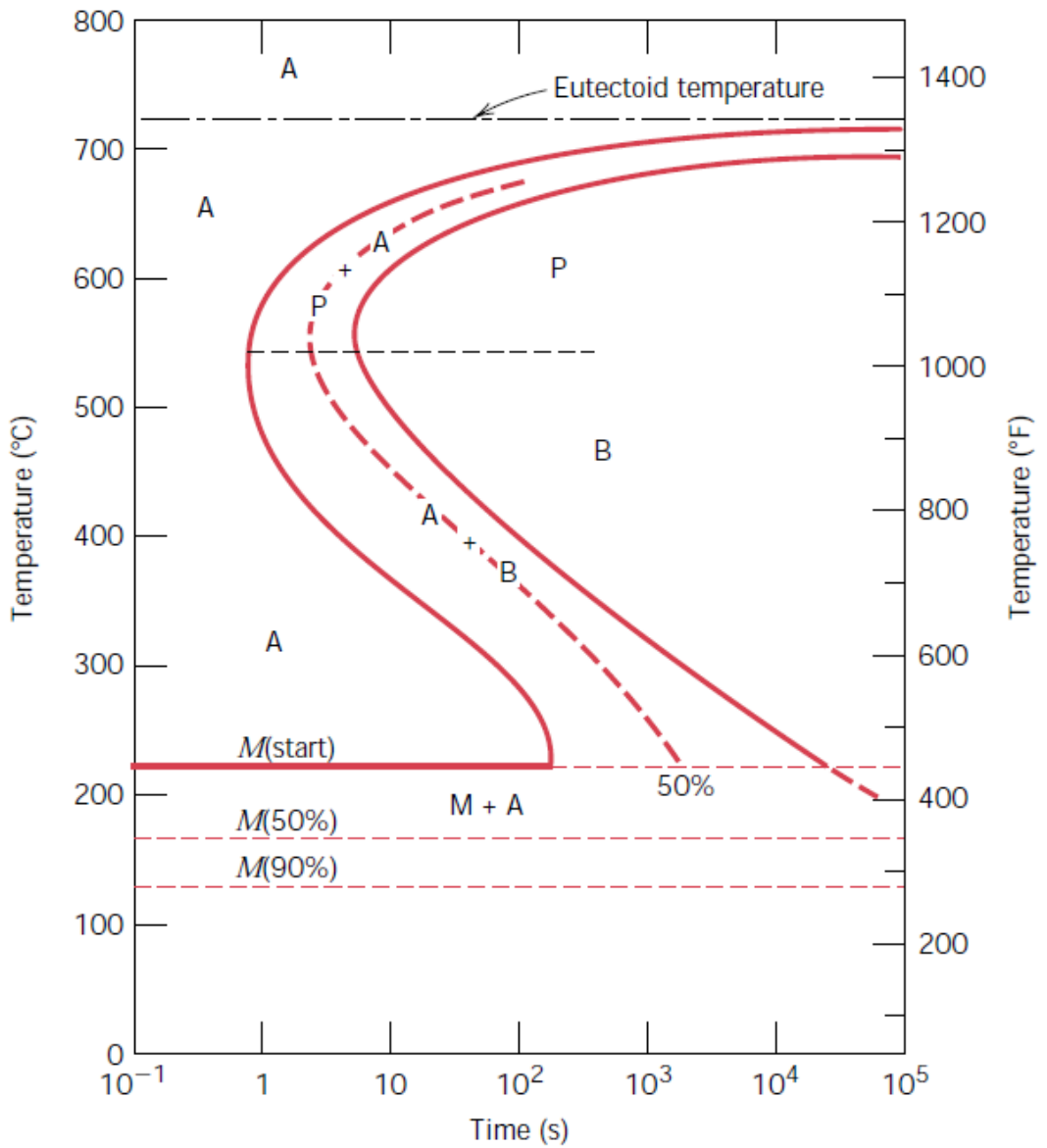

Figure 2.3: TTT Curve for a eutectoid steel [4]. 
When the steel crosses a start line on the TTT graph the austenite formed at the high temperature will begin to transform. Depending on the cooling rate, any of the start lines can be crossed, and the respective microstructures will begin to form. Quenching quickly below the martensite start temperature will result in the transformation martensite, resulting in a strong and hard structure that is brittle [5]. Figure 2.4 shows a martensitic structure. The martensitic transformation involves the changing of the crystal structure to body centered tetragonal, which stretches the vertical axis of the unit cell in a shear process, going from a face-centered cubic structure to a body-centered tetragonal structure [6]. This stretching effect results in stresses formed in the material, and in severe cases can lead to what is known as "quench cracking" $[2,5]$. Two main types of martensite form, based on carbon content. Lath martensite forms in steels of composition up to 0.6 weight $\%$ carbon, while plate martensite forms in steels over 1 weight $\%$ carbon. It is possible to form mixes of lath and plate martensite in steels between $0.6 \mathrm{wt} \%$ and 1 wt\% carbon [2].

Several equations have been produced to calculate the martensite start temperatures based on the specific effect that each alloying element has on the start temperature $[7,8]$. Equation 2.1 is the formula for martensite start temperature, first presented in 1965 by Andrews [9]. It is of particular use for steels which have low carbon content. Other equations have been determined for use with steels with lower carbon contents, or alloyed with different alloying elements $[7,8]$. One such equation, for carbon contents up to $0.02 \mathrm{wt} \%$, proposed by Liu et al, is given in Equation 2.2 [8].

$$
M_{S}\left({ }^{\circ} \mathrm{C}\right)=539-423 \mathrm{C}-30.4 \mathrm{Mn}-12.1 \mathrm{Cr}-17.7 \mathrm{Ni}-7.5 \mathrm{Mo} \quad \text { Equation 2.1 }
$$




$$
\begin{aligned}
M_{S}\left({ }^{\circ} \mathrm{C}\right)=525-350(C-0.005)-45 M-35 V(N b+Z r+T i) \\
-30 C r-20 N i-16 M o-8 W-5 S i+6 C o+15 A l
\end{aligned}
$$

\section{Equation 2.2}

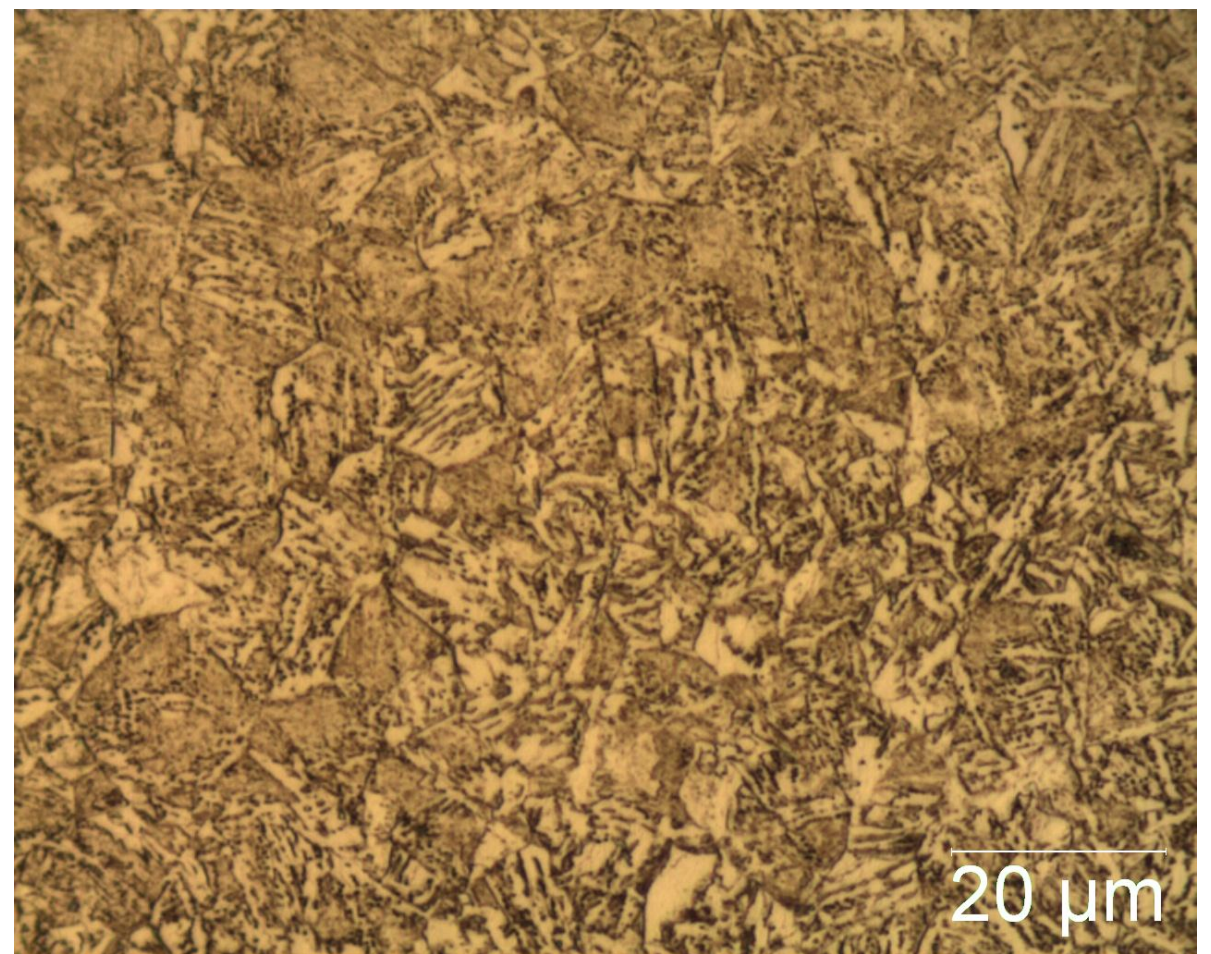

Figure 2.4: Martensite formed in core of 4320 steel carburized and austempered at 500 ${ }^{\circ} \mathrm{F}$ for 2 hours

Bainite is a non-lamellar mix of ferrite and cementite formed at intermediate cooling rates. There are two types of bainite, upper and lower bainite, which form depending on the temperature ranges used. They can be identified by their different appearances, Figure 2.5. Lower bainite has a more needle like appearance, and forms with a shearing mechanism similar to martensite, although there are some diffusion effects present as well $[2,10]$. Upper bainite has a more feathery appearance, and is produced predominantly by diffusion mechanisms. Lower bainite is formed upon cooling to a temperature just above the $\mathrm{M}_{\mathrm{s}}$ temperature and holding, while upper bainite can be formed by cooling past the pearlite shelf of the TTT curve and holding at temperature. 
Lower bainite tends to have a higher tensile strength and hardness than upper bainite [11].

Much like martensite there have been attempts to characterize the bainite start temperature. Work by Zhao et al. produced Equation 2.3, a bainite start temperature equation for low alloy steels $[12,13]$. It is assumed that the bainite start temperature marks the "knee" of the cooling curve that has to be passed before bainite can be formed. This equation does not take into effect the necessary cooling rate required to avoid pearlite formation. Using bainite start temperature equations as a guide it is possible to approximate the TTT curve for a given steel using empirical testing to find the times required for transformation [14]. Upon crossing the bainite start line on the TTT curve, bainite will begin to form. If the transformation process is interrupted by a quench it is possible to only partially transform the austenite to bainite. The austenite which has yet to transform will transform to martensite upon quenching; any untransformed austenite will remain trapped in the bainite matrix as retained austenite at room temperature.

$$
\begin{gathered}
B_{S}\left({ }^{\circ} \mathrm{C}\right)=630-45 \mathrm{Mn} \%-40 \mathrm{~V} \%-35 \mathrm{Si} \%-30 \mathrm{Cr} \%-\quad \text { Equation } 2.3 \\
25 \mathrm{Mo} \%-20 \mathrm{Ni} \%-15 \mathrm{~W} \%
\end{gathered}
$$



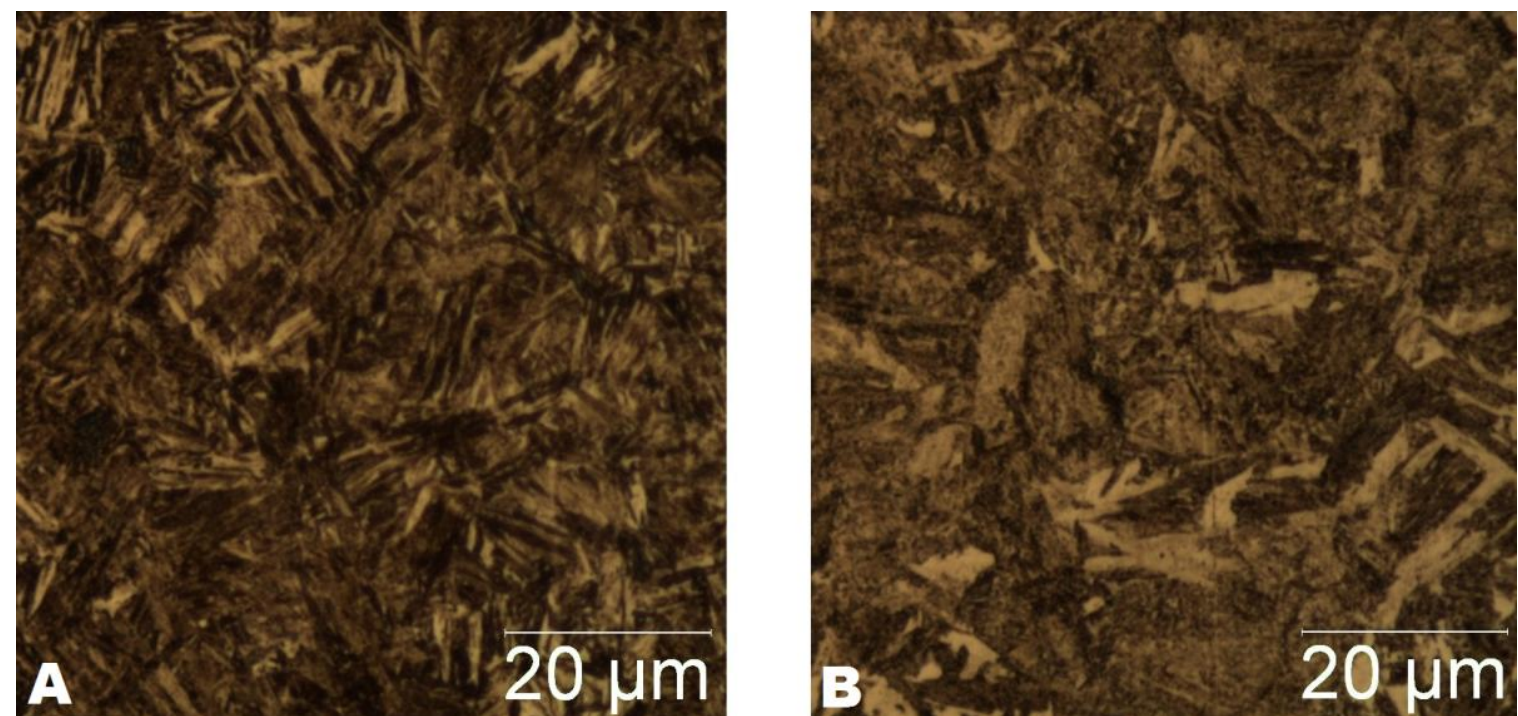

Figure 2.5: (A) Lower bainite, with a needle like appearance. (B) Upper bainite, with a more feathery appearance

\subsection{Alloying Effect on the TTT Curve}

It is not possible with a plain carbon steel to design a heat-treatment schedule to form bainite and martensite from austenite. The proeutectoid and pearlite start lines on the TTT curve do not allow enough time to quench to an austempering temperature or the martensite start temperature before the proeutectoid and eutectoid reactions begin. Hence any microstructure would contain a finite amount of pearlite and a proeutectoid phase. The hardenability, or ease of forming martensite, of steel can be increased by adding alloying elements to the steel $[15,16]$. These alloying elements shift the pearlite start line to longer times, allowing sufficient cooling time to allow the formation of bainite and martensite. Figure 2.6 shows a TTT curve for 4340 steel, an alloy steel of nickel and chrome. 


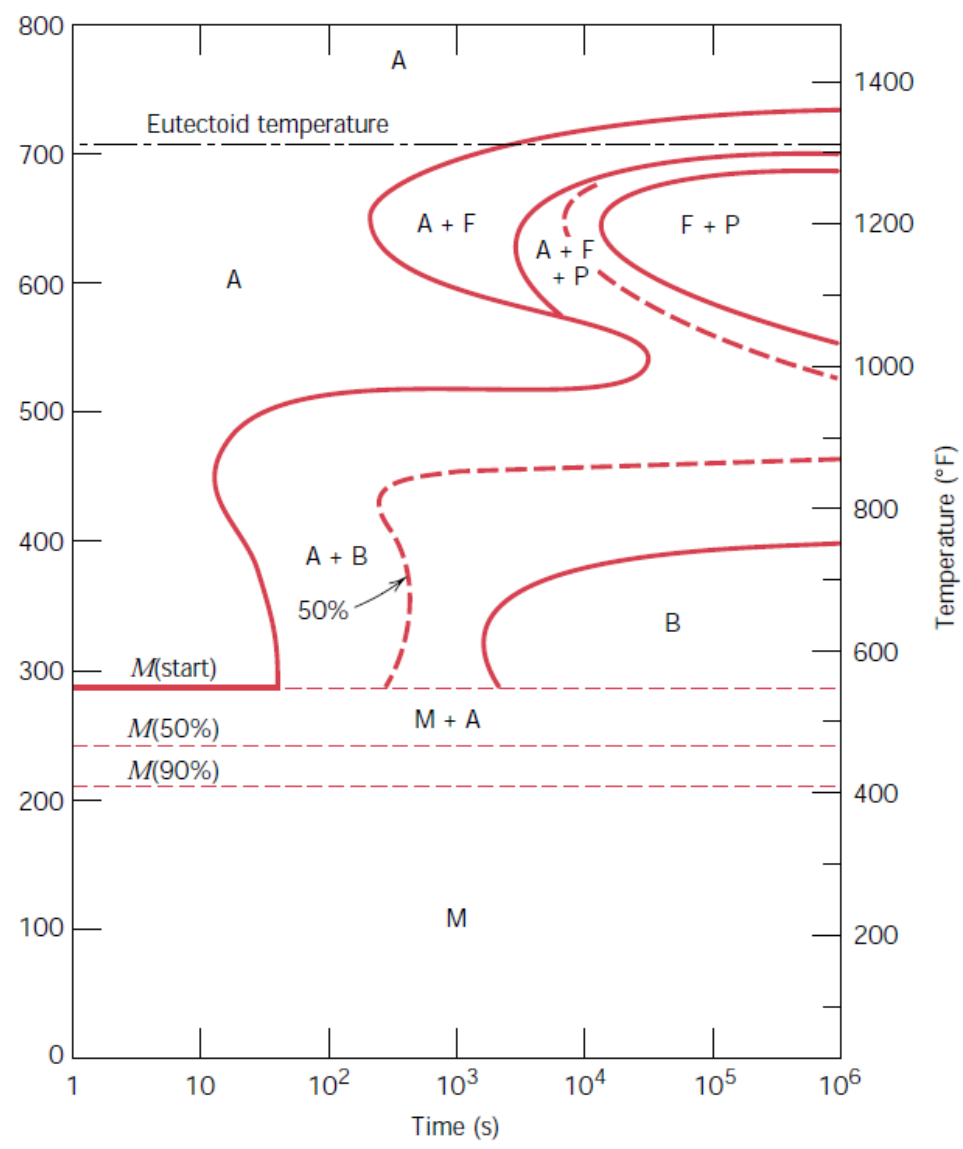

Figure 2.6: TTT curve for 4340 steel showing the bainite shelf [4]

\subsection{Case Hardening}

Case hardening describes a series of processes where in the outer layer of a component is provided increased hardness. It is desirable where components will be subject to friction and wear. There are several methods of case hardening steel; such as carburizing, carbonitriding, nitriding, laser surface hardening, and induction hardening $[17,18]$. Carburizing is most often performed using a two stage gas carburizing process known as boost diffuse processing; it requires less time than the traditional single stage carburizing [19]. The first stage, the boost, is carried out by placing the component into a high temperature furnace, typically between $1550{ }^{\circ} \mathrm{F}$ and $1750^{\circ} \mathrm{F}[2,5,20]$, with a high carbon potential atmosphere. The carbon potential is higher than the final desired carbon 
content of the material, which "boosts" the carbon content in the surface layer of the material to close to the desired amount. In the second stage, the carbon potential of the atmosphere is lowered to the desired carbon potential and held at a slightly lower temperature $[21,22]$. The higher carbon content at the surface then diffuses farther into the lower carbon content areas of the case [2, 20]. The carburized layer offers additional hardness on the surface, while maintaining for a tougher, lower-carbon, core [16].

Of all the alloying elements in steel, carbon has the largest effect on hardenability. Hence it is possible to form a different microstructure at the surface of a case carburized component compared to the microstructure found in the core. Hardenability can also be affected by prior austenite grain size. Grain size can be increased by using a higher temperature for austenitizing, or, in case hardening, a higher carburizing temperature [23].

\subsection{Heat Treatment Processes}

The heat treatment process used to bring the component from the high furnace temperature to room temperature can affect the final properties of the material. After carburizing, a steel can be slow cooled, then reheated to austenitize it before performing a final heat treatment [24]. Quench and tempering (Q\&T) is currently the most common method of heat treating case carburized parts [25]. In the quench and temper process the parts are directly oil quenched from the carburizing process to form martensite in both the case and core, and then reheated to temper the martensite, thereby increasing the ductility and toughness. Typical tempering temperatures are in the range of 300 to $400{ }^{\circ} \mathrm{F}(149$ to $205^{\circ} \mathrm{C}$ ), although these can be considerably higher depending on what type of tempering 
is being undertaken $[17,26]$. A TTT curve showing the quench and tempering process is shown in Figure 2.7. Upon full transformation to martensite, any subsequent tempering will not result in the transformation to bainite or pearlite. The tempering reaction allows carbon from the super saturated martensite lattice to form cementite particles at the prior austenite grain boundaries or between the martensite laths and plates. It is the lowering of the carbon content in the martensite that results in the increase in ductility and toughness.

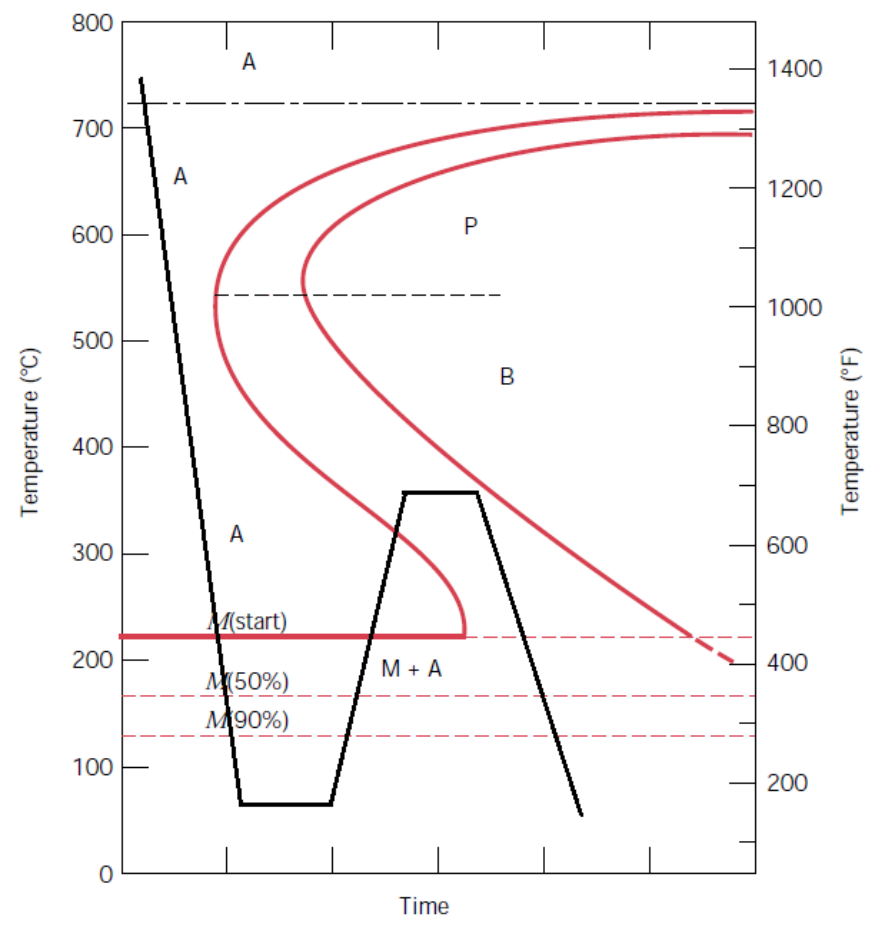

Figure 2.7: Quench-and-temper process on a TTT curve [4].

The tempering process generally allows for an increase of ductility and toughness. However, depending on the temperature ranges selected, it is possible to make the material more brittle. Tempered martensite embrittlement is a phenomenon where at certain ranges of temperature, generally between 500 and $700{ }^{\circ} \mathrm{F}$. It is possible for 
alloying elements to not only reduce the effectiveness of a temper, but make the material more brittle [2].

Austempering is a different heat treatment process. After carburizing, the part is quenched to an intermediate temperature and held to allow the formation of bainite within the carburized case of the sample [27]. Bainite is able to form in the carburized case because its high carbon content has lowered the $M_{S}$ temperature to below the hold temperature. Typically, salt baths are employed as a quenchant for austempering, and the part is washed with water afterwards. Reclamation of both salt and water can allow for austempering to produce nearly no waste, although there are costs associated with the reclamation process [28]. As well, austempering can remove the need for additional distortion-correcting treatments, associated with quenched parts, to prepare the material for service; as well it reduces the chance of hydrogen embrittlement [29, 30]. Figure 2.8 shows an austempering process on a TTT curve. Line A shows an interrupted transformation and would result in a mostly martensitic and retained austenite structure with some bainite, line B shows an interrupted transformation which would result in a mostly bainitic structure with some martensite and retained austenite, and line $\mathrm{C}$ shows a transformation which would yield an entirely bainitic microstructure. 


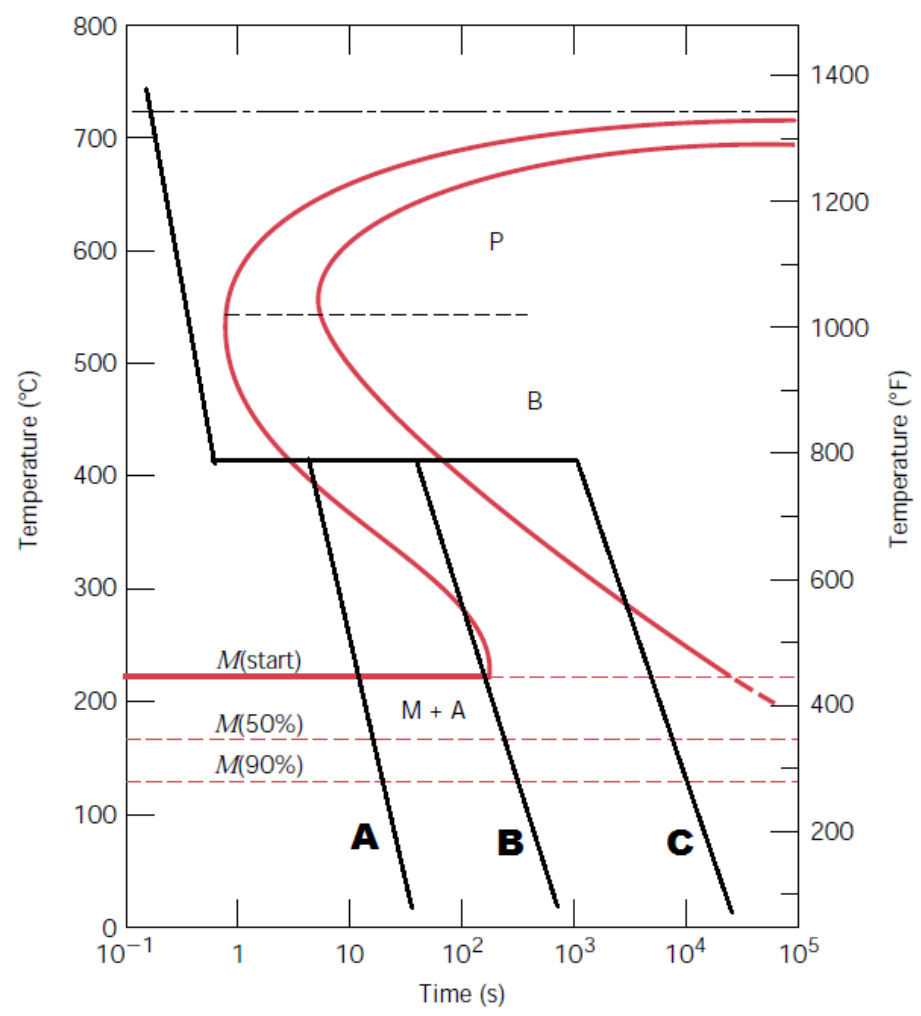

Figure 2.8: TTT Curve showing three austempering heat treatments to produce different amounts of bainite [4].

\subsection{Distortion Effects}

Distortion, or non uniform volume change, occurs during the quenching of parts as a result of both phase transformations, as well as thermal expansion and contraction. Distortion is divided into two main categories, size and shape distortion. Size distortion is most commonly associated with thermal expansion and contraction, while shape distortions tend to arise due to local temperature differences and differences in section size during cooling [31]. Although it is possible to predict with some accuracy the size distortion that will take place during heat treatment, it is difficult to predict the shape distortions which will occur, because they depend on local variations in cooling rate. Distortion results in a need for post-heat-treatment grinding to restore the part 
dimensions. If distortion is severe enough, parts have to be scrapped [32]. Dimensional correction can cause weakening of a case carburized material, as well as increase production times and costs $[33,34]$. As such reduction in distortion becomes an important aspect of part design. By changing the heat treatment method, distortion can be reduced. In this study, distortion is measured with a coordinate measurement machine (CMM) by comparing dimensions of a Navy C-ring sample both before and after case carburizing and heat treatment.

\subsubsection{The Navy C-Ring}

The Navy C-ring has both thick and thin sections, which allows for the shape of the sample to change during heat treatment. It is a standard shape used to measure the effects of distortion during processing; its use has been well documented to measure the distortion effects associated with heat treatments [31, 35, 36, 37, 38]. A modified Navy C-ring is shown in Figure 2.9.
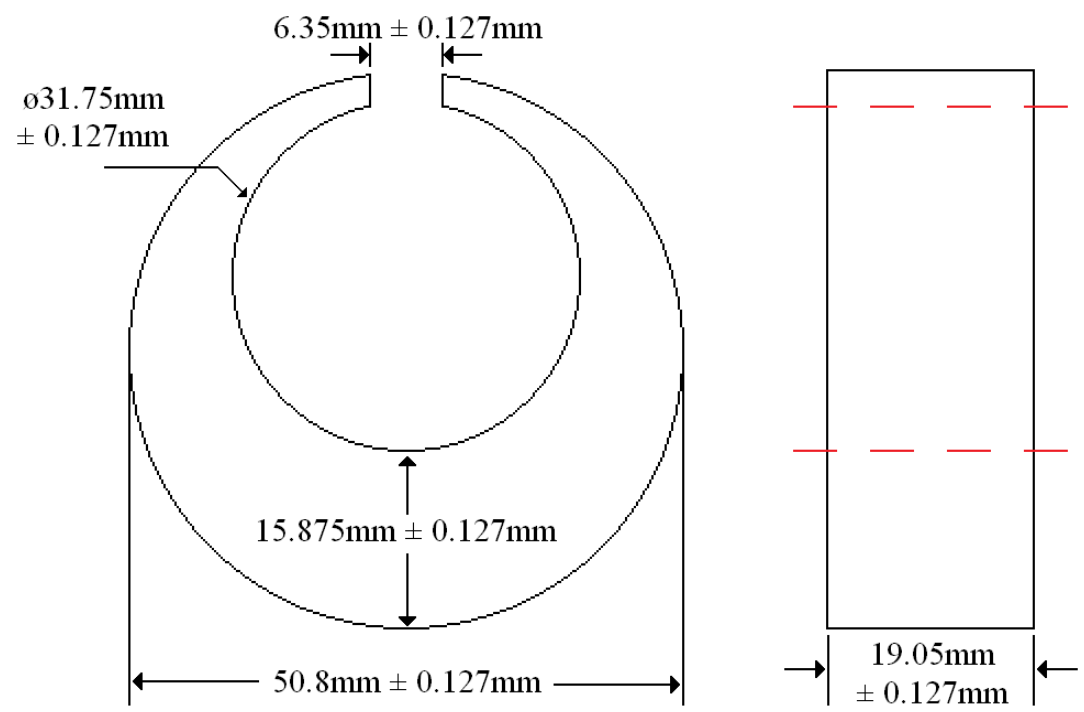

Figure 2.9: A Modified Navy C-ring [31, 35]. 
There are seven standard measurements made on the Navy C-ring, divided into size and shape distortions. Size distortions relate to the changing of major dimensions. They include the inner and outer diameters, thickness of the sample, and are most often caused by volume changes associated with phase transformations. The quenching of austenite to form martensite results in a positive volume change of $4.63 \%$ for a $0.02 \mathrm{wt} \%$ C steel [39]. Table 2.1 shows volume change resulting from steel phase transformations as a function of carbon content. Shape transformations are most often associated with both heat treatment variables, as well as thermal expansion and contraction through parts of varying thickness. The result is a deviation from the desired angles and shapes of the part. Shape distortions are quantified on the Navy C-ring by using the flatness, roundness, cylindricity, and gap width measurements.

Table 2.1 - Volume change associated with phase transformations [39].

\begin{tabular}{cc} 
Transformation & Volume Change \% \\
\hline Pearlite $->$ Austenite & $-4.64+2.21 \times(\mathrm{C} \%)$ \\
Austenite $->$ Martensite & $4.64-0.53 \times(\mathrm{C} \%)$ \\
Austenite $->$ Lower Bainite & $4.64-1.43 \times(\mathrm{C} \%)$ \\
Austenite $->$ Upper Bainite & $4.64-2.21 \times(\mathrm{C} \%)$
\end{tabular}

\subsection{Residual Stress}

Similar to distortion, residual stress is caused by both phase transformations, as well as thermal expansion and contraction; it can be affected by the heat treatment conditions placed upon a material $[35,40]$. As steel is cooled, different sections of the material will transform at different temperatures, most often due to variances in composition [41]. Residual stresses are formed as sections of the material change size at 
different rates. Typically with carburized steels, the residual stress is compressive at the surface, and increases in magnitude immediately below the surface. Farther into the material, the stress returns to surface levels, becomes tensile, then approaches zero [39, 42, 43]. A typical distribution of residual stress into the carburized case of a steel is shown in Figure 2.10 [44].

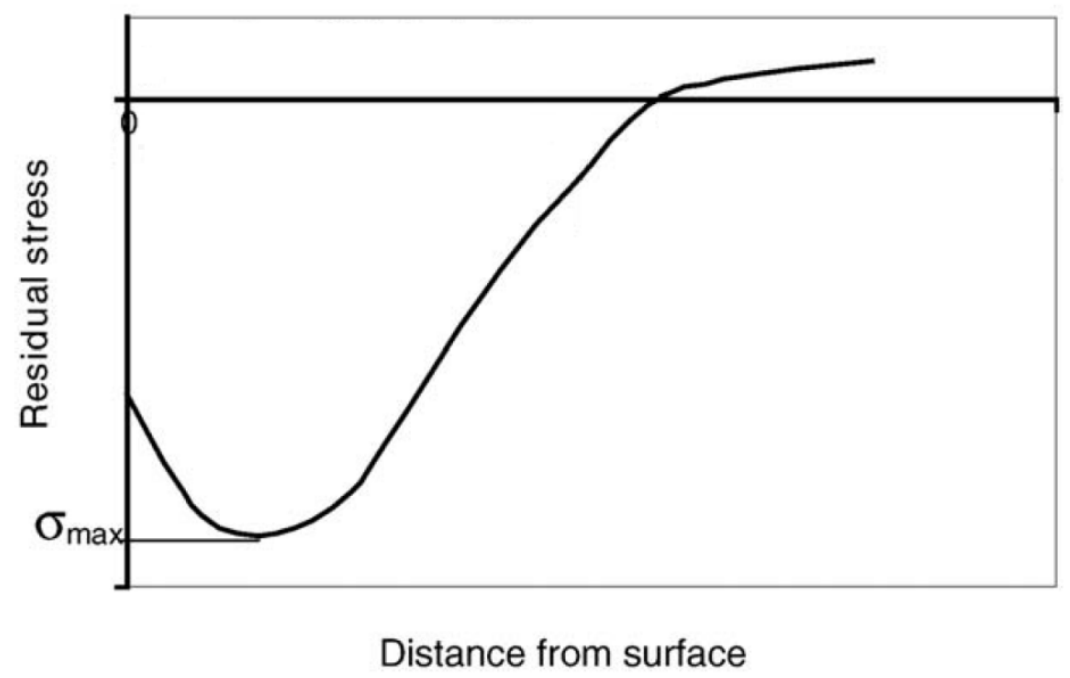

Figure 2.10: Typical residual stress depth profile found in carburized steel. Reproduced from [44].

Residual stresses can be beneficial or detrimental to performance depending on their nature. Compressive residual stresses are preferred over tensile ones, because they can help improve wear and fatigue resistance $[45,46]$. Should any cracks form in the material, the compressive stresses have the ability to relax and prevent crack growth. Attempts have been made to correlate the exact effect of residual stress on fatigue life; however, no studies have been able to do so conclusively [47]. Fatigue life is of particular importance in the production of gears, and austempering has been shown to increase the fatigue life of a material over traditional quench-and-tempering processes [48]. 
There are several methods of measuring residual stress: destructive methods such as inferometric strain rosettes with hole drilling; and non-destructive methods, including $\mathrm{X}$-ray diffraction [49]. X-ray diffraction measures the stresses within a material by measuring the crystallographic lattice spacings and comparing them to an unstressed sample [50]. Typically, this unstressed sample is a powder which has been furnace annealed to allow the stresses present in the material to relax [40]. The strain is calculated using Equation 2.4, where $d_{o}$ is the lattice spacing of the unstressed powder.

$$
\varepsilon=\left(d-d_{o}\right) / d_{o}
$$

Equation 2.4

The lattice planes diffract the x-ray beam when the beam hits the material, which causes a change in the peak intensity of the diffracted beam [40,51]. It is through the use of the wavelength, angle of refraction, and a constant near unity that the lattice spacing, $d$, is calculated. This is shown in Equation 2.5, known as Bragg's Law [51]. It is demonstrated visually in Figure 2.11, where the X-ray beams are the dashed lines, and the horizontal dotted lines are the lattice.

$$
n \lambda=2 d \sin \theta
$$

Equation 2.5

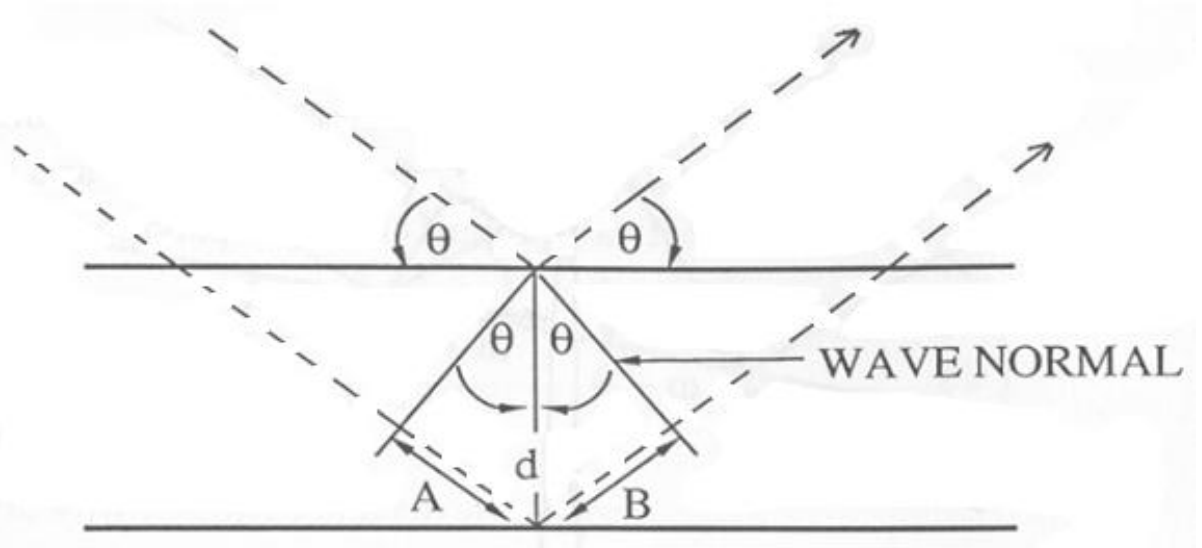

Figure 2.11: Bragg's law demonstrated visually [52]. 
The $\sin ^{2} \Psi$ method involves taking a larger number of $d$ spacing measurements and accounting for the angle of the $h k l$ Miller index planes found in the lattice. In Equation 2.6 the $\frac{1}{2} S_{1}$ and $\frac{1}{2} S_{2}$ terms are x-ray elastic parameters of the material, $\sigma_{\phi}$ is the stress in the direction of measurement, $\psi$ is the angle subtended by the bisector of the incident and diffracted beam and the surface normal, and $\varepsilon_{\phi \psi}$ is the strain associated with a particular $\psi$ angle [53].

$$
\begin{gathered}
\varepsilon_{\phi \psi}=\frac{1}{2} S_{2}\left(\sigma_{\phi}-\sigma_{33}\right) \sin ^{2} \psi+\frac{1}{2} S_{2} \sigma_{33}-S_{1}\left(\sigma_{11}+\sigma_{22}+\sigma_{33}\right)+ \\
\frac{1}{2} S_{2} \tau_{\phi} \sin 2 \psi
\end{gathered}
$$

Equation 2.6

This equation allows for the calculation of stress within a material without having to use the annealed powder method to get the zero strain value [40]. Figure 2.12 shows the orientation of the various stress components. The $\sin ^{2} \Psi$ method allows for more accuracy in measurement with increased collection time and more $\psi$ angles. For examination of residual stresses at greater depths, material must be removed, because xray diffraction is not able to penetrate deeply into a material [54]. One method used to remove material is electro polishing; however, corrections must be made to the measurements to account for the material removed by the electropolishing process [55]. 


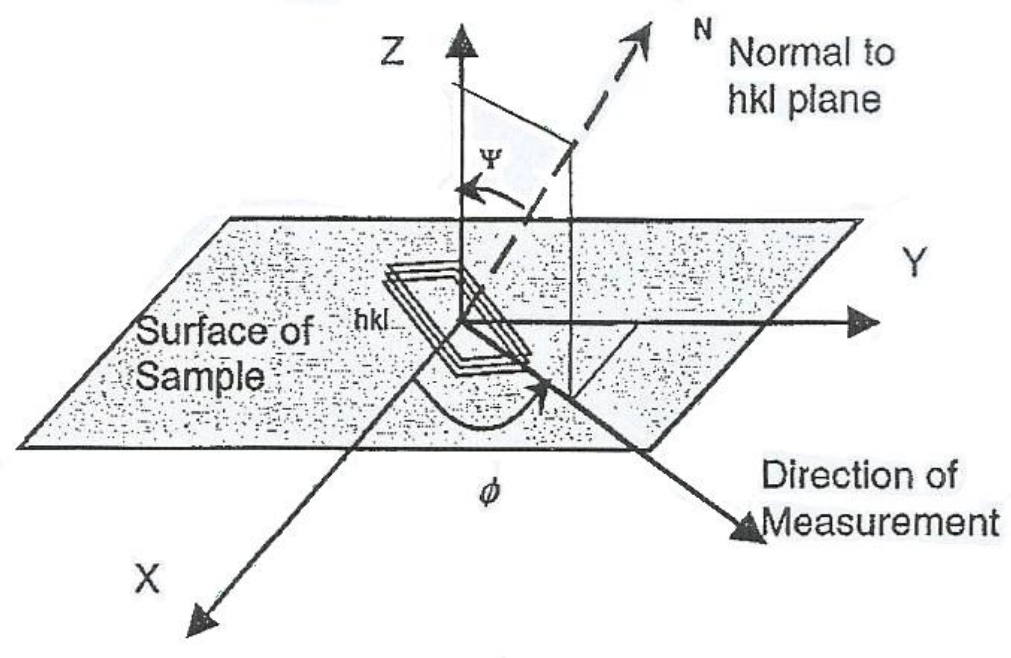

Figure 2.12: Axes and Directions Used in X-Ray Diffraction [40, 53].

\subsection{Retained Austenite}

Retained austenite occurs when there is an incomplete transformation to a new structure during the quenching of a steel. It is a common occurrence in case hardened steels, as the additional carbon content in the case of the part lowers the martensite finish temperature to such a point that complete transformation is difficult to achieve $[46,56]$. The low $M_{f}$ temperature, combined with a rapid quench can result in even more retained austenite at the end of the quenching process. It is often seen that there can be between $20 \%$ and $30 \%$ retained austenite in carburized steel at the surface [24]. Retained austenite levels increase with carbon content [10].

Retained austenite levels are also commonly measured using X-ray diffraction techniques, although other measurement techniques exist [57]. When using X-ray diffraction to measure retained austenite levels the "four peak method" is most commonly used. This method measures the intensities of the $\{211\}$ and $\{200\}$ families of planes in 
the martensite, and compares them to the $\{200\}$ and $\{220\}$ families of planes in the austenite [58].

Retained austenite can be further transformed by the application of either strain or heat treatment. Strain application allows the shear process to take place, and results in a martensitic microstructure. Heat treatment, such as the tempering process used in the production of quench-and-tempered parts, will result in the retained austenite decomposing into bainite, either upper or lower bainite depending on the temperature. Retained austenite can also allow for benefits in the fatigue life of a carburized steel, as the retained austenite is associated with compressive residual stress, and in higher strain cases, the transformation of retained austenite through deformation accommodates some of the strain [59].

\subsection{Mechanical Properties}

\subsubsection{Hardness}

Hardness is measured using a variety of scales depending on material and expected hardness. It can be measured on both the micro and macro level, with separate scales existing for each. Case hardness can be used to get a rough estimate of both strength and wear resistance of a case hardened material [29]. Core hardness can give an indication of the toughness that can be expected for a material. Hardness testing on the Rockwell scale is outlined in ASTM [60]. 


\subsubsection{Toughness}

Toughness is a measure of the energy absorbed by a material before fracture. ASTM Standard E23-12c, Standard Test Methods for Notched Bar Impact Testing of Metallic Materials, outlines two types of impact tests, the Charpy and Izod tests. Most commonly used in North America is the Charpy V-notch test [61], which uses a notched specimen. Other notch geometries are available, as outlined in the ASTM standard. Charpy testing is performed by using a weighted pendulum to break notched sample. When the pendulum swings and breaks the sample, the height to which it swings on the opposite side is recorded, and the energy absorbed by the sample is measured.

For carburized parts, Charpy toughness is often recognized as a function of the core microstructure. In steels that had not been carburized, it was demonstrated that austempering to form a lower bainitic structure produced better toughness than quenchand-tempering [25].

Impact energy can be heavily influenced by temperature as well as heat treatment. The ductile-to-brittle transformation temperature (DBTT) is a temperature at which a steel will go from having lower-energy fracture to higher-energy fracture [2, 61]. Ideally, a material will have a lower DBTT than the temperature at which it will be in service. Nickel and molybdenum have the ability to increase toughness and lower the DBTT. An increase in carbon content can greatly lower toughness and increase the DBTT [62]. With Charpy impact tests, it is possible to examine the method of failure, similar to the way a tensile test failure mode can be determined. Ductile fracture is associated with increased toughness; brittle fracture is associated with decreased toughness. 


\section{EXPERIMENTAL DETAILS}

Austempering and quench-and-tempering processes were compared in three different carburizing grades of steel by means of microstructural, mechanical properties, and distortion properties testing. Twelve initial austempering parameters were reduced to 7 after microstructural examination of the case. Further micrographs were produced for both the case and core of the quench-and-tempered conditions, as well as the remaining austempering conditions. Hardness measurements were recorded for both the case and the core of both conditions. Charpy impact testing was used to determine the fracture energy of the materials. Distortion resulting from heat treatment was measured using a coordinate measurement machine $(\mathrm{CMM})$. Residual stress and retained austenite measurements were made using X-ray diffraction.

\subsection{Material Selection}

Three steels were examined in this study, SAE 8620, 8822, and 4320. Their chemical compositions are shown in Table 3.1. They were selected for testing based on their current, frequent use in the carburized state. All three steels are common carburizing grades, varying in hardenability, strength, and toughness, and seeing use for gears, roller bearings, and piston pins. 8620 steel features good hardenability, medium strength, and, when case hardened, good wear resistance. It is the most commonly used of the three steels examined. 8822 steel has good case hardenability and core hardness, as well as higher strength than 8620 steel due to its higher carbon content [1]. 4320 steel is a nickelchrome-molybdenum steel; it has a higher nickel content compared to the other two materials, and generally higher toughness. Martensite start temperatures were calculated using the formula of K.W. Andrews, Equation 3.1, and converted into Fahrenheit for both 
the case and core. $M_{S}$ temperatures for the carburized cases were calculated based on 0.9 wt\% carbon [9].

Table 3.1 - Compositions of Tested Steels

\begin{tabular}{|c|c|c|c|c|c|c|c|c|}
\hline Steel & wt\% C & wt\% Mn & wt\% Si & wt\% Cr & wt\% Ni & wt\% Mo & $\begin{array}{c}M_{s} \\
\text { Core }\end{array}$ & $\begin{array}{c}M_{s} \\
\text { Case }\end{array}$ \\
\hline 8822 & 0.22 & 0.96 & 0.17 & 0.56 & 0.34 & 0.33 & $754^{\circ} \mathrm{F}$ & $236^{\circ} \mathrm{F}$ \\
\hline 8620 & 0.2 & 0.91 & 0.23 & 0.5 & 0.56 & 0.16 & $769^{\circ} \mathrm{F}$ & $236^{\circ} \mathrm{F}$ \\
\hline 4320 & 0.19 & 0.64 & 0.2 & 0.47 & 1.74 & 0.22 & $753^{\circ} \mathrm{F}$ & $213^{\circ} \mathrm{F}$ \\
\hline
\end{tabular}

$$
M_{S}\left({ }^{\circ} C\right)=539-423 C-30.4 M n-12.1 C r-17.7 N i-7.5 M o \quad \text { Equation 3.1 }
$$

\subsection{Heat treatment}

Carburization was performed using gas carburizing at a temperature of $1650{ }^{\circ} \mathrm{F}$ for five hours, with a carbon potential of 0.9. Salt baths were used to austemper the samples, at one of three temperatures: 500,550 , or $580^{\circ} \mathrm{F}$; for one of four times: 30,60 , 120, or 240 minutes. There were twelve time-temperature combinations. Quench and tempered samples were oil quenched to room temperature, then reheated and tempered at either 650 or $750{ }^{\circ} \mathrm{F}$ for one hour. These temperatures were selected to demonstrate the upper range of tempering. Table 3.2 provides an overview of the heat treatment parameters. 
Table 3.2 - Initial Heat Treatment Conditions

\begin{tabular}{|c|c|c|}
\hline $\begin{array}{l}\text { Treatment } \\
\text { Method }\end{array}$ & Temperature $\left({ }^{\circ} \mathrm{F}\right)$ & Time (min) \\
\hline \multirow{12}{*}{ Austemper } & \multirow{4}{*}{500} & 30 \\
\hline & & 60 \\
\hline & & 120 \\
\hline & & 240 \\
\hline & \multirow{4}{*}{550} & 30 \\
\hline & & 60 \\
\hline & & 120 \\
\hline & & 240 \\
\hline & \multirow{4}{*}{580} & 30 \\
\hline & & 60 \\
\hline & & 120 \\
\hline & & 240 \\
\hline \multirow{2}{*}{$\begin{array}{l}\text { Quench \& } \\
\text { Temper }\end{array}$} & 650 & 60 \\
\hline & 750 & 60 \\
\hline
\end{tabular}

\subsection{Optical Microscopy}

Optical microscopy was used to examine the amount of bainite in the case of the austempered samples. Samples were mounted in diallyl pthalate using a Buehler Simplimet mounting press. Grinding was performed using a Buehler Handimet 2 with silicon carbide papers of 240, 320, 400, and 600 grit. After grinding, the samples were rough polished with a 9-micrometer diamond paste, followed by fine polishing with 1.0and 0.05 - micrometer aluminium suspensions. Etching was accomplished using a $2 \%$ nital solution. Austempered microstructures showed a mixture of bainite and martensite in the case and martensite in the core. Quench-and-tempered samples show martensite in both the case and core. A minimum limit of 50\% bainite in the case was set to determine 
the austempering conditions for further study. Figure 3.1 shows an example of sufficient and insufficient bainite in a microstructure. Table 3.3 identifies the final selected heat treatments.
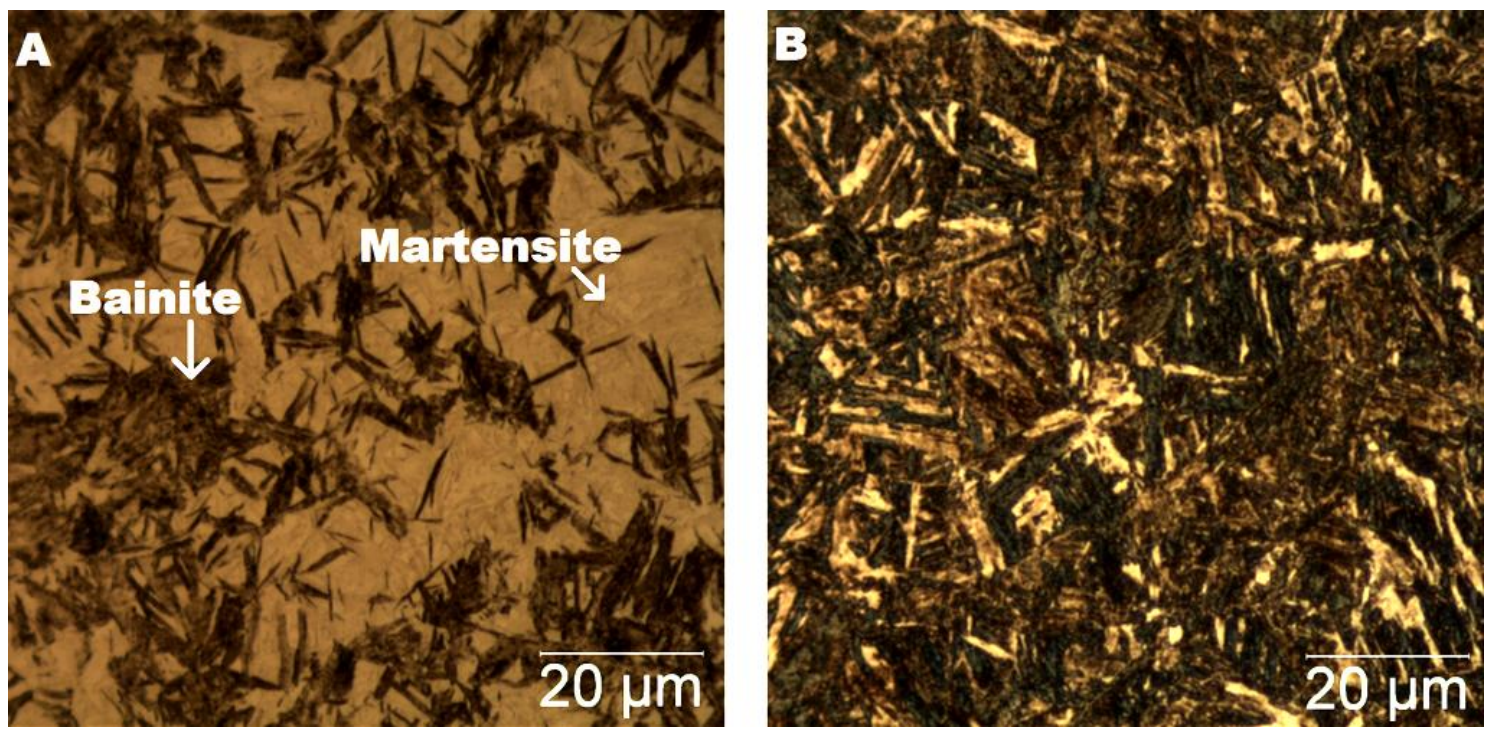

Figure 3.1: 4320 steel carburized then austempered at $500{ }^{\circ} \mathrm{F}$ for (A) 30 minutes and (B) 120 minutes. The darker phase is identified as bainite. The lighter phase is martensite. There was less than $50 \%$ bainite in (A) so further testing was not warranted.

Table 3.3 - Heat Treatment Parameters Selected for Further Study

\begin{tabular}{|c|c|c|c|}
\hline $\begin{array}{c}\text { Treatment } \\
\text { Method }\end{array}$ & Temperature $\left({ }^{\circ} \mathrm{F}\right)$ & Time (min) & $\begin{array}{c}\text { Parameter } \\
\text { ID }\end{array}$ \\
\hline \multirow{4}{*}{ Austemper } & 500 & 120 & $500 / 2$ \\
\cline { 2 - 4 } & \multirow{2}{*}{550} & 240 & $500 / 4$ \\
\cline { 2 - 4 } & \multirow{2}{*}{580} & 120 & $550 / 2$ \\
\cline { 2 - 4 } & & 240 & $550 / 4$ \\
\cline { 3 - 4 } & & 60 & $580 / 1$ \\
\hline \multicolumn{2}{|c|}{} & 240 & $580 / 2$ \\
\hline $\begin{array}{c}\text { Quench \& } \\
\text { Temper }\end{array}$ & 750 & 60 & QT650 \\
\cline { 2 - 4 } & & 60 & QT750 \\
\hline
\end{tabular}




\subsection{Distortion Analysis}

Navy C-ring samples were employed to characterize distortion. Two C-rings were machined for each austempering condition as well as for each quench-and-temper condition. Identification numbers can be found in Table 3.4.

Table 3.4 - Identification numbers of Navy C-Rings

\begin{tabular}{|c|c|c|c|c|}
\hline Material & 8620 & 8822 & 4320 & \\
\hline Code & A & B & $\mathrm{C}$ & \\
\hline Heat Treatment & $\begin{array}{l}\text { Temperature } \\
\text { (F) }\end{array}$ & Time (h) & Number & $\begin{array}{l}\text { Parameter } \\
\text { ID }\end{array}$ \\
\hline \multirow{7}{*}{ Austemper } & 500 & 2 & $\begin{array}{l}13 \\
14\end{array}$ & $500 / 2$ \\
\hline & 500 & 4 & $\begin{array}{l}3 \\
4\end{array}$ & $500 / 4$ \\
\hline & 550 & 2 & $\begin{array}{l}11 \\
12\end{array}$ & $550 / 2$ \\
\hline & 550 & 4 & $\begin{array}{l}5 \\
6\end{array}$ & $550 / 4$ \\
\hline & 580 & 1 & $\begin{array}{l}7 \\
8\end{array}$ & $580 / 1$ \\
\hline & 580 & 2 & $\begin{array}{c}9 \\
10\end{array}$ & $580 / 2$ \\
\hline & 580 & 4 & $\begin{array}{l}1 \\
2\end{array}$ & $580 / 4$ \\
\hline \multirow{2}{*}{$\begin{array}{l}\text { Quench \& } \\
\text { Temper }\end{array}$} & 650 & 1 & $\begin{array}{l}17 \\
18 \\
\end{array}$ & QT650 \\
\hline & 750 & 1 & $\begin{array}{l}15 \\
16\end{array}$ & QT750 \\
\hline
\end{tabular}

Distortion analysis was performed using a coordinate measurement machine (CMM). Measurements of the C-ring specimens were made both before the carburizing + heat treating process, as well as after. The equation used to calculate the distortion amount is shown in Equation 3.2, where $x_{1}$ is the measured value before carburizing+ heat treating, and $x_{2}$ is the measured value after carburizing + heat treatment. Averages 
were calculated, and standard deviation was calculated using Equation 3.3 where $\sigma$ is the standard deviation.

$$
\begin{gathered}
\text { Distortion } \%=\left(\frac{x_{2}-x_{1}}{x_{1}}\right) \times 100 \% \\
\text { Standard Deviation } \sigma=\sqrt{\frac{\sum(x-\bar{x})^{2}}{(n-1)}}
\end{gathered}
$$

Equation 3.2

Equation 3.3

Seven types of distortion were measured, four size and three shape distortions. Size distortions are inner diameter (ID), outer diameter (OD), thickness, and gap width. Shape distortions are flatness, roundness, and cylindricity. A diagram of the Navy C-ring showing nominal dimensioning values, as well as measurement locations for the different distortion types, is given in Figure 3.2.

Size distortion measurements were taken as follows. Diameters were measured using diametrically opposed points on the inner and outer circumferences at both of the flat surfaces of the C-ring, as well as on the plane midway between the two. Thickness was measured at five points on the outer diameter, as the distance between the two flat surfaces of the C-ring. Each of the five measurements is reported. Gap width is a measurement of the distance between the two surfaces at the gap cut at the thinnest section; it was measured along both vertical edges as well as at the centre of the gap.

Shape distortion measurements were taken as follows. Approximately 2400 flatness measurements were performed along the edges of the surface of the C-ring which was marked with the specimen identification code. The difference between the highest and lowest points was the reported flatness value. A sample test plot from the CMM 
machine is shown in Figure 3.3. The small circles on the test plot indicate the highest and lowest points on the edges of the surface

Cylindricity measures both the inner and outer diameters for their consistency in the axial direction. 2800 points were used to measure the ID; 4500 points were used to measure the OD. ID and OD were measured at both flat surfaces as well as the sample mid-height. The difference between the innermost and outermost points gives the cylindricity measurement. Figure 3.4 shows the output plot from a CMM machine for inner cylindricity. The small circles on the plot indicate the innermost and outermost points relative to the black dot, which marks the central axis of the circle being measured.

Roundness measurements were made on the inner and outer diameters at the flat surfaces and mid-height. The largest and smallest radii were recorded, and then the difference reported as the roundness value for that plane of measurement. As a result, 6 measurements are reported, one for each plane measured for both the inner and outer diameter. A test plot from the CMM is shown in Figure 3.5. The plot for roundness shows the three measurements, scaled so as to not overlap. The blue circles indicate the actual measurement, with the red marks on them noting the innermost and outermost points. 


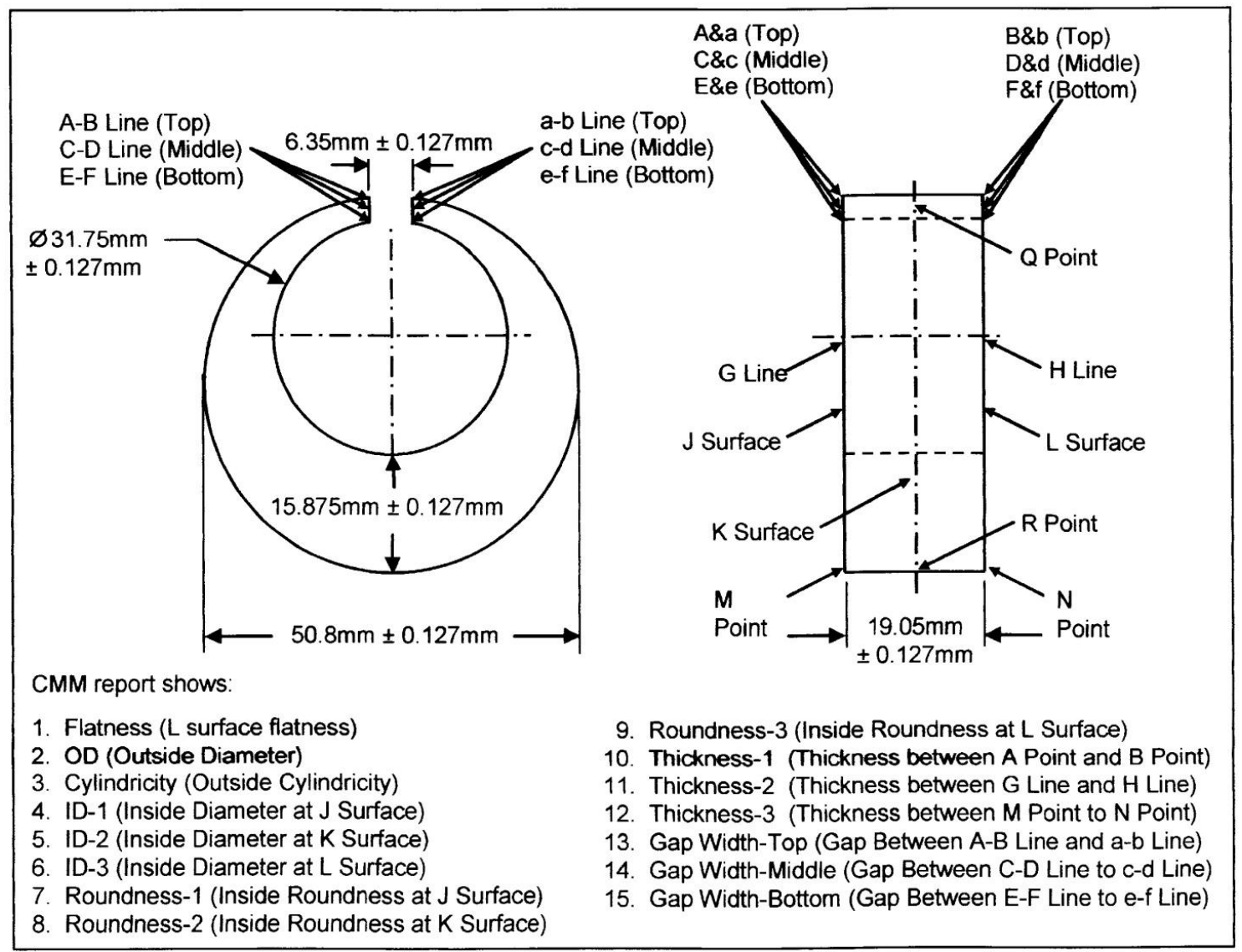

Figure 3.2: C-Ring Dimensioning Diagram [31, 35]. 


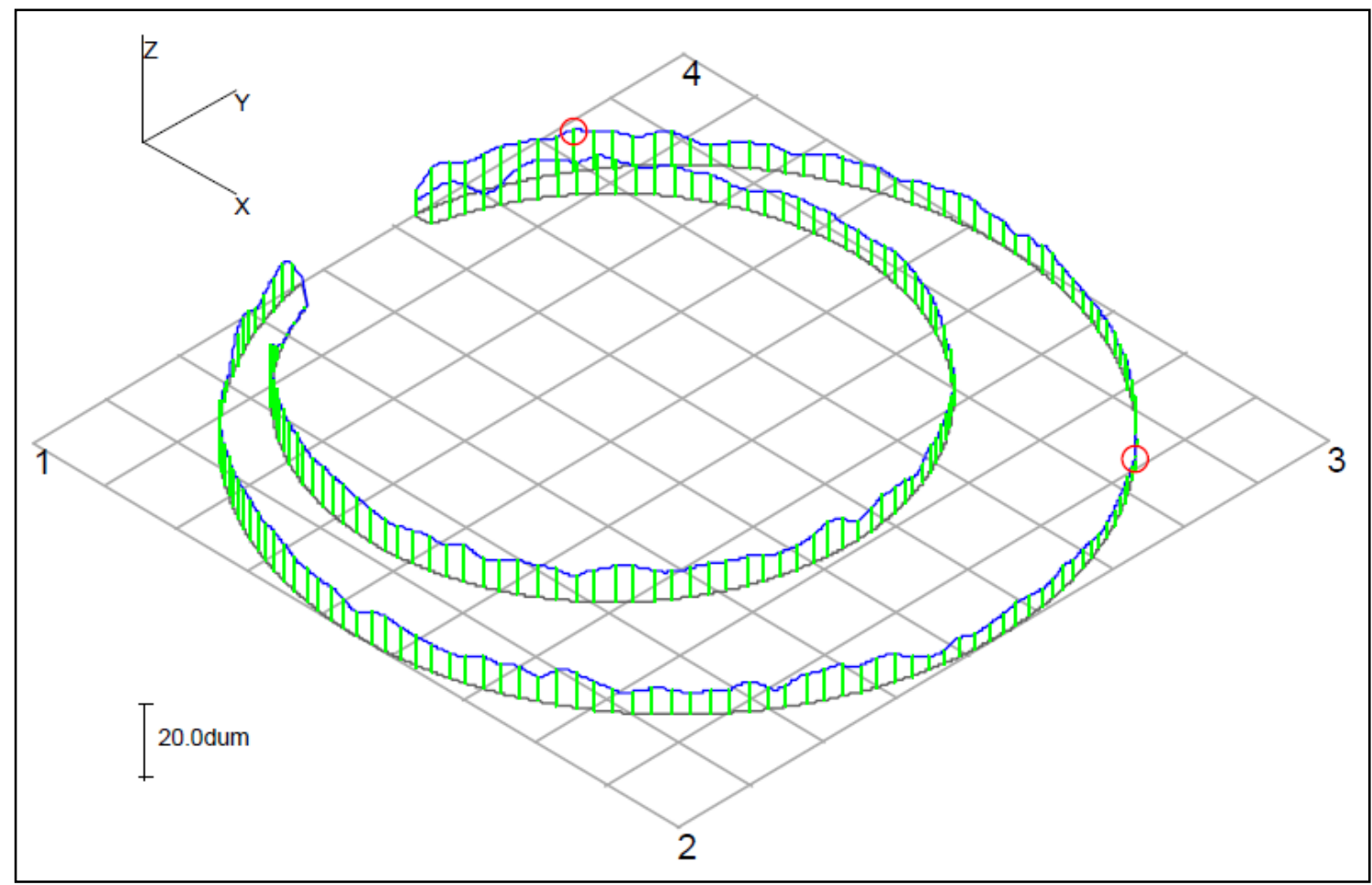

Figure 3.3: Flatness Test Plot Produced by CMM - Circles indicate the highest and lowest points of deviation from the ideal plane.

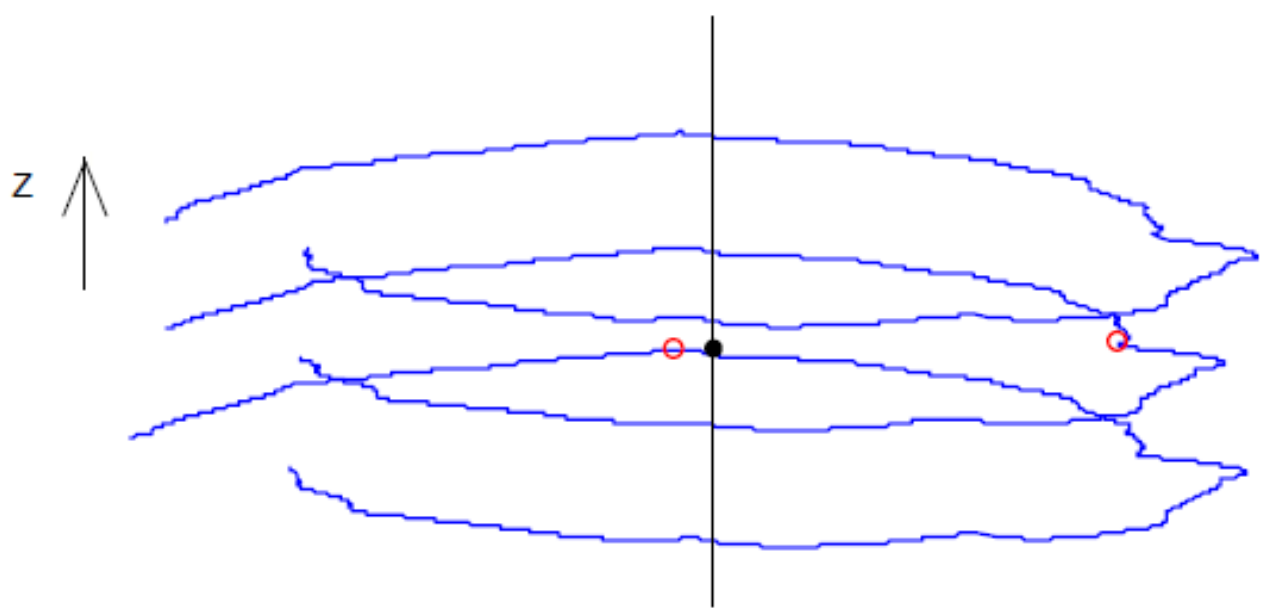

Figure 3.4: Inner Cylindricity Test Plot Produced by CMM - Circles indicate the innermost and outermost points relative to the central axis. 


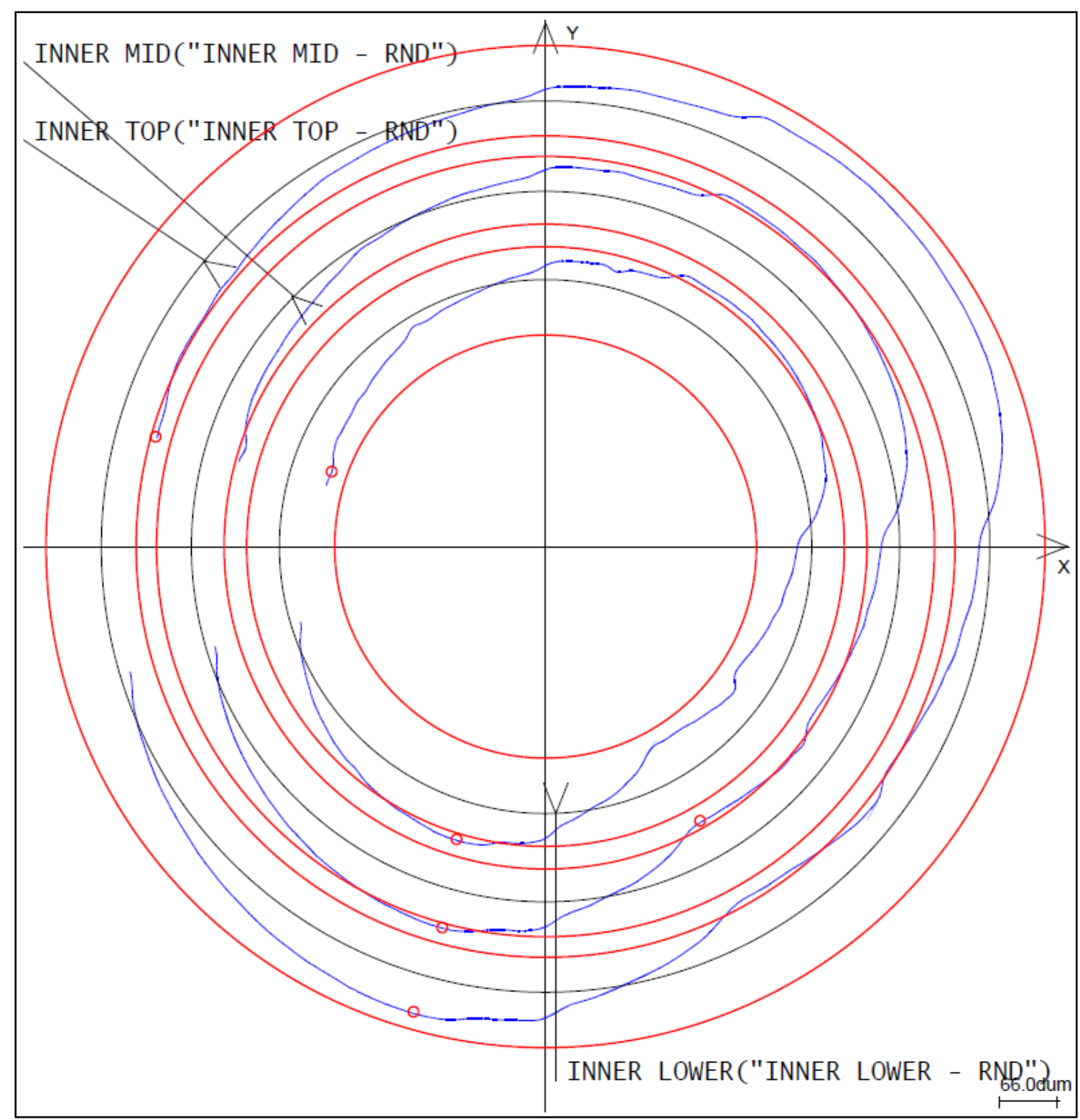

Figure 3.5: Roundness Test Plot Produced by CMM - Plot displays all three planes of measurement. Measurements are scaled to display all 3 measurements without overlapping. 


\subsection{Residual Stress}

Residual stress measurement was carried out using X-ray diffraction techniques. $\mathrm{CrK} \alpha$ radiation of wavelength 2.291 Angstroms was used, at a power of $30.00 \mathrm{kV}, 25.00$ mA. The 211 family of planes were measured, with the Bragg angle held at $156.4^{\circ}$. Eleven psi angles $(\psi)$ were used, at $0, \pm 25.00, \pm 20.59, \pm 15.83, \pm 11.84$, and \pm 3.71 degrees. An aperture of $1 \mathrm{~mm}$ was used. Calibration was performed in accordance with ASTM E915, using iron powder for both surface and depth testing [50].

Figure 3.6 shows a C-ring positioned for residual stress measurement on the surface, and subsurface at the "R" point identified in Figure 3.2. Residual stress measurements were made on one C-ring from each austempered condition, and one from each quench-and-tempered condition for the 4320 steel. 4320 steel was selected for testing based on its distortion and mechanical properties performance, the results of which are covered in chapter 4. Additionally, residual stress depth profile testing was performed on two of the 4320 steel C-rings; one austempered at $500{ }^{\circ} \mathrm{F}$ for 4 hours; the other quench-and-tempered at $750{ }^{\circ} \mathrm{F}$ for one hour. For depth testing, electro polishing was used to remove surface layers to reach the desired depths. Measurements were taken at 10 depths, with a maximum depth of 0.1 inches. Exact measurement depths for both Crings are shown in Table 3.5. 

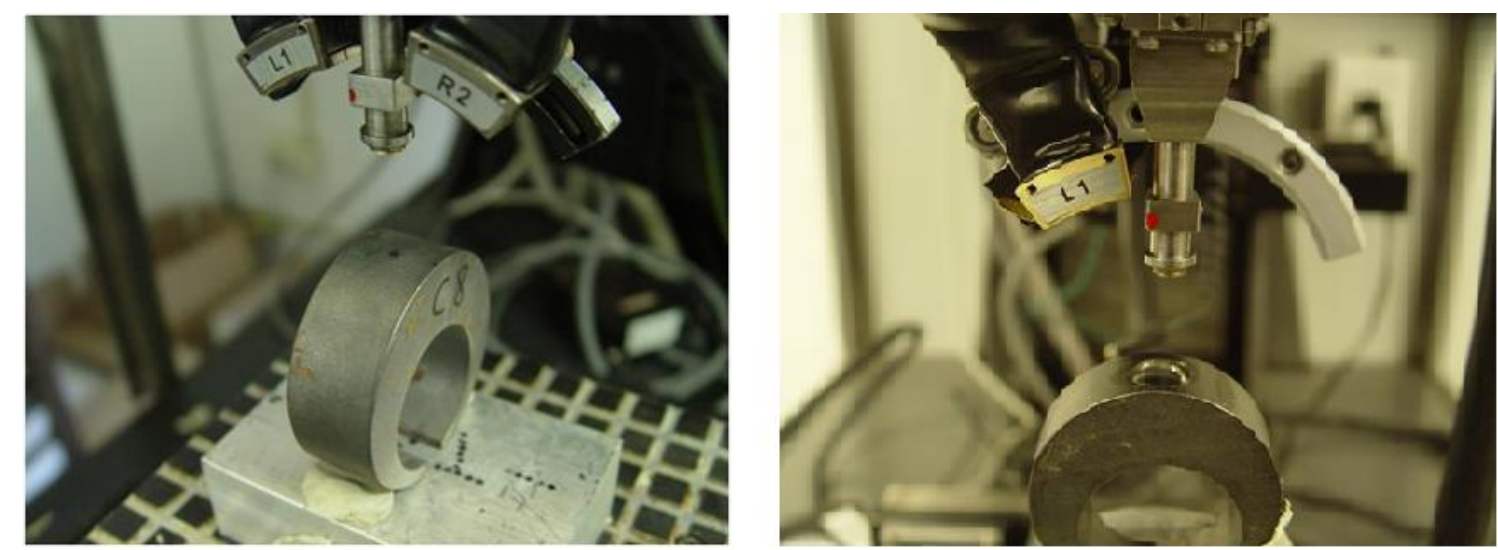

Figure 3.6: C-Ring positioned for surface residual stress measurement (left) and after electropolishing (right).

Table 3.5 - Residual Stress Measurement Depths for 4320 Steel

\begin{tabular}{|c|c|c|}
\hline Condition & $500 / 4$ & QT750 \\
\hline \multirow{4}{*}{$\begin{array}{c}\text { Measurement } \\
\text { Depths (in) }\end{array}$} & 0.0000 & 0.0000 \\
\cline { 2 - 3 } & 0.0006 & 0.0060 \\
\cline { 2 - 3 } & 0.0011 & 0.0012 \\
\cline { 2 - 3 } & 0.0030 & 0.0028 \\
\cline { 2 - 3 } & 0.0052 & 0.0048 \\
\cline { 2 - 3 } & 0.0103 & 0.0107 \\
\cline { 2 - 3 } & 0.0200 & 0.0235 \\
\hline & 0.0454 & 0.0403 \\
\cline { 2 - 3 } & 0.0666 & 0.0686 \\
\cline { 2 - 3 } & 0.1016 & 0.0997 \\
\hline
\end{tabular}

\subsection{Retained Austenite}

Similar to the residual stress profile, a depth profile of retained austenite levels was produced for one of the two 4320 steel 500/4 samples, and one of the two QT750 samples. Samples were chosen based on their distortion and residual stress results. X-ray diffraction was used to determine the amount of retained austenite to a depth of $1 / 16^{\text {th }}$ of an inch. Exact measurement depths are shown in Table 3.6. A beam of $\mathrm{CrK} \alpha$ radiation was used with a wavelength of 2.291 Angstroms. Power levels were $30.00 \mathrm{kV}, 25.00 \mathrm{~mA}$. 
The four peak method was used to measure the retained austenite. Electro polishing was used to remove surface material to expose the surface underneath. Retained austenite measurements were carried out at certain depths in conjunction with residual stress measurement.

Table 3.6 - Retained Austenite Measurement Depths for 4320 Steel

\begin{tabular}{|c|c|c|}
\hline Condition & $500 / 4$ & QT750 \\
\hline \multirow{4}{*}{$\begin{array}{c}\text { Measurement } \\
\text { Depth (in) }\end{array}$} & 0.0000 & 0.0000 \\
\cline { 2 - 3 } & 0.0011 & 0.0012 \\
\cline { 2 - 3 } & 0.0052 & 0.0048 \\
\cline { 2 - 3 } & 0.0103 & 0.0107 \\
\cline { 2 - 3 } & 0.0200 & 0.0235 \\
\hline
\end{tabular}

\subsection{Mechanical Properties}

Mechanical properties testing consisted of hardness testing and Charpy impact testing.

\subsubsection{Hardness}

Case and core hardness were tested on all samples using a Wilson Rockwell hardness tester, verified in accordance with ASTM E18, Standard Test Methods for Rockwell Hardness of Metallic Materials [60]. Five measurements were taken for both the case and core using a diamond cone with a 150 kilogram load. For each measurement, the highest and lowest results were eliminated, and the average of the remaining three measurements was recorded. 


\subsubsection{Charpy Impact Testing}

Charpy impact testing was performed on all samples using Type A Charpy (simple beam) impact test specimens, machined in accordance with the dimensions in ASTM E23. Specimens were machined, then carburized and heat treated. A diagram of the Type A Charpy test specimen is given in Figure 3.7 [61]. Three Charpy test specimens were produced for each austempering condition, as well as for the two quench and tempered conditions. Additionally two Charpy specimens were produced which were carburized, oil quenched, then tempered at $350^{\circ} \mathrm{F}$ for one hour to simulate the currently used carburization with quench-and-temper process. The fracture surfaces of selected samples were examined using a scanning electron microscope (SEM).

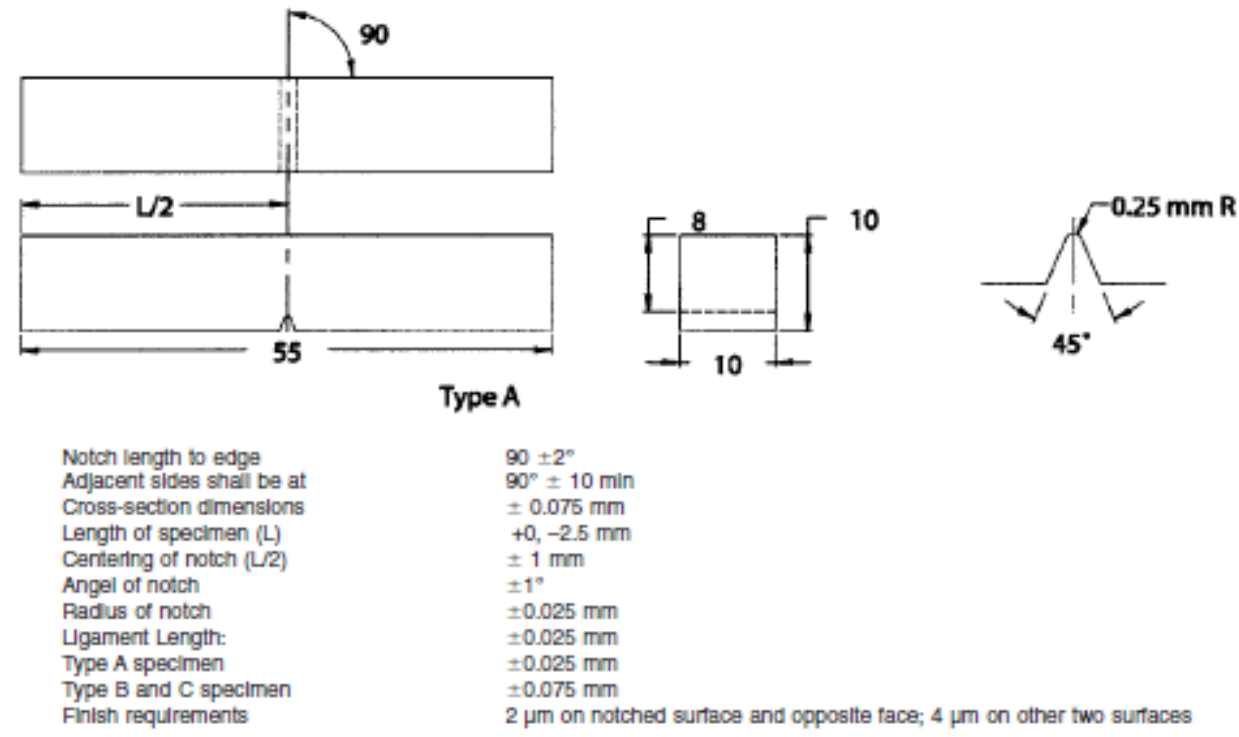

Figure 3.7: Dimensions of Type A Charpy Test Specimen from ASTM E23 [61]. 


\section{RESULTS \& DISCUSSION}

A comparison of the austempering process with the quench and tempering process was accomplished for three carburized steel compositions. Microstructural analysis of the effects of tempering time and temperature was undertaken to explain the effect on mechanical properties. Distortion is quantified by an examination of Navy C-Ring dimensions taken before carburizing and after the subsequent carburizing and heat treatment processes. X-ray diffraction was employed to quantify residual stress and retained austenite both at as well as beneath the surface of the Navy C-Rings. While the austempering process was generally found to be equivalent or better than the traditional quench-and-tempering process, the issues of wear performance and a more quantitative focus on the economics of process substitution remain.

\subsection{Microstructure}

The case microstructures found in 8620 steel after the initial carburizing and austempering heat treatment processes are documented in Figure 4.1. For each temperature-time combination, Table 3.2, bainite was noted to form. For the 30-minute processes, complete transformation to bainite did not occur; the remainder of the microstructure was martensite.

A level of $50 \%$ bainite was identified as being necessary to obtain the similar or improved mechanical properties compared to the current quench-and-temper condition. As such, the initial austempering trials were able to eliminate all of the 30-minute austempering conditions for all three steels: 8620,4320 , and 8822 , as well as the 60 -

minute conditions for 500 and $550{ }^{\circ} \mathrm{F}$. Figures 4.2 and 4.3 document the microstructures 
for the 4320 and 8822 steels, respectively, that were noted to contain a minimum $50 \%$ bainite.

For the 8620 steel, the type of bainite formed depended on the temperature. The more feathery appearing upper bainite was noted at $580^{\circ} \mathrm{F}$; acicular lower bainite was noted at $500^{\circ} \mathrm{F}$. Hence, the TTT curve for this steel would exhibit a bainite curve with its nose between 580 and $500^{\circ} \mathrm{F}$. Longer times at lower temperatures resulted in carbide precipitation at the edges of the bainite needles, Figures 4.1.G and 4.1.J.

The microstructures of the austempered 4320 steel, Figure 4.2, exhibited upper bainite across the temperature range. As such, the TTT curve for this steel would have its bainite nose situated below $500^{\circ} \mathrm{F}$. For the 8822 steel, the situation was similar to the 8620 steel, with upper bainite present at $580^{\circ} \mathrm{F}$ and lower bainite at $500^{\circ} \mathrm{F}$. The effect of microstructure on mechanical properties is discussed in section 4.4 . 

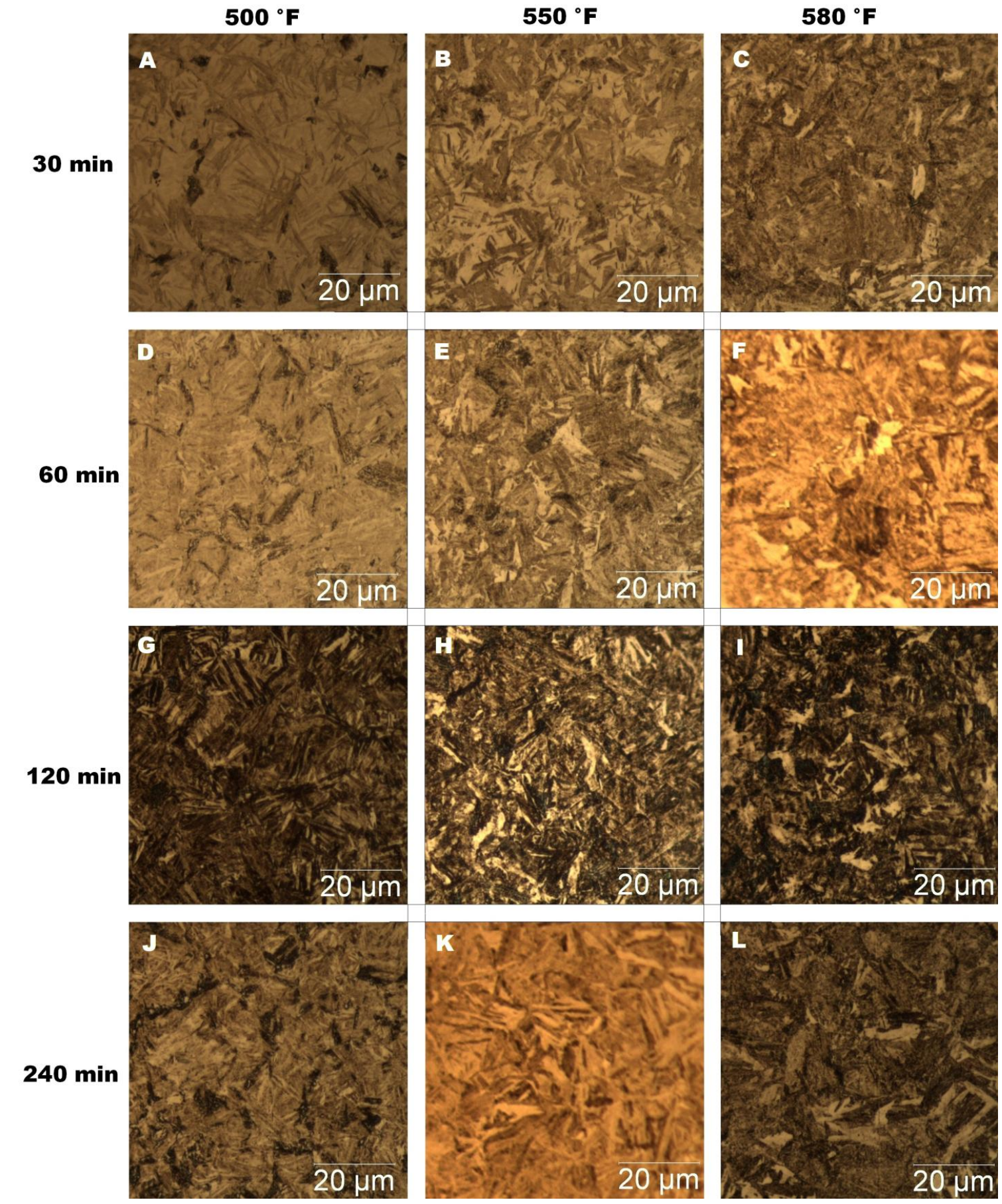

Figure 4.1: Austempered 8620 steel case microstructures.

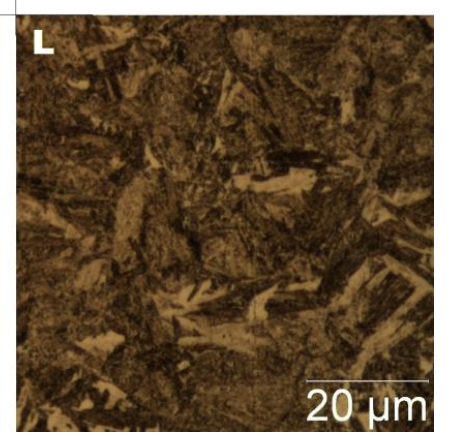




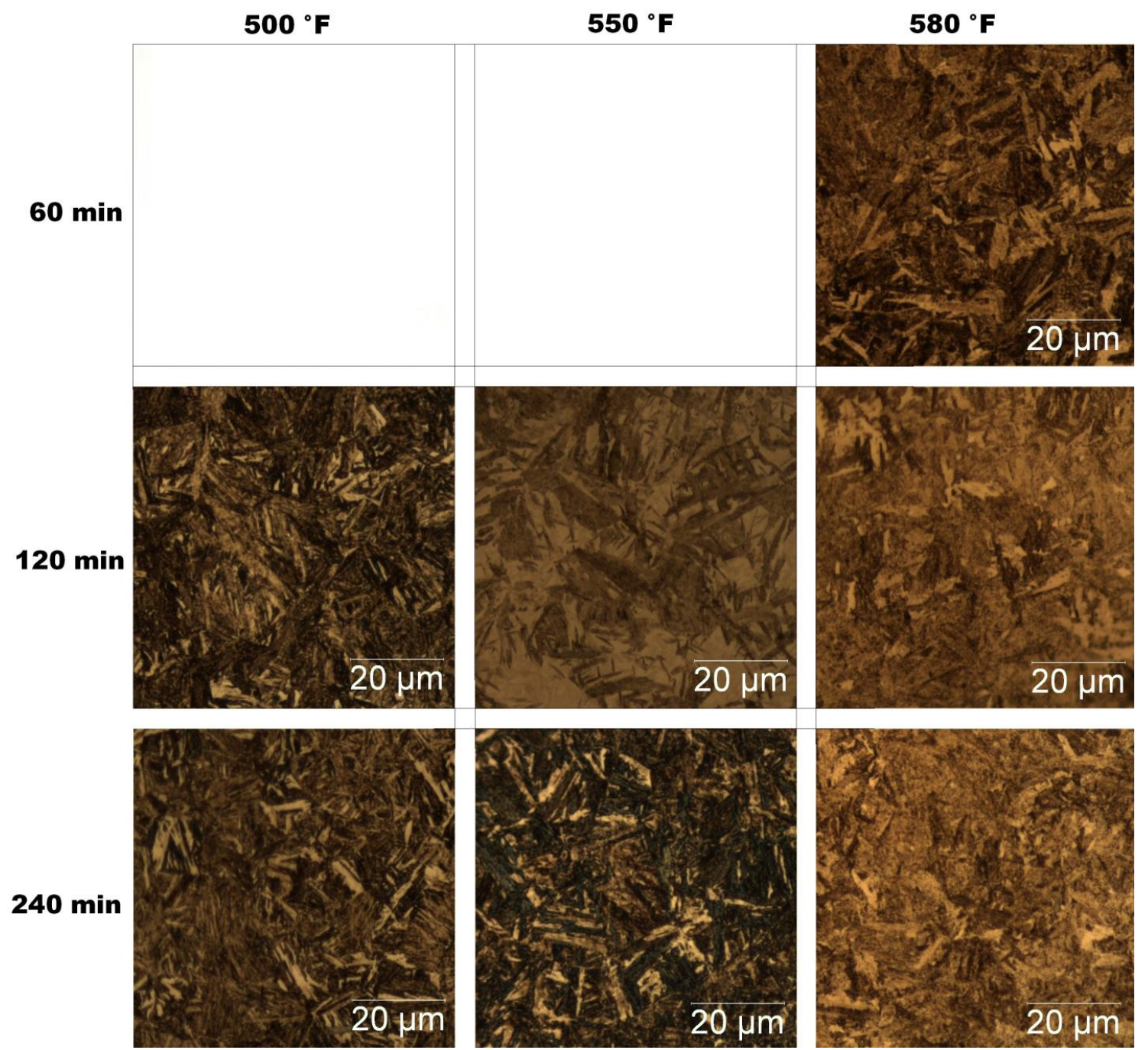

Figure 4.2: Austempered 4320 steel case microstructures. 


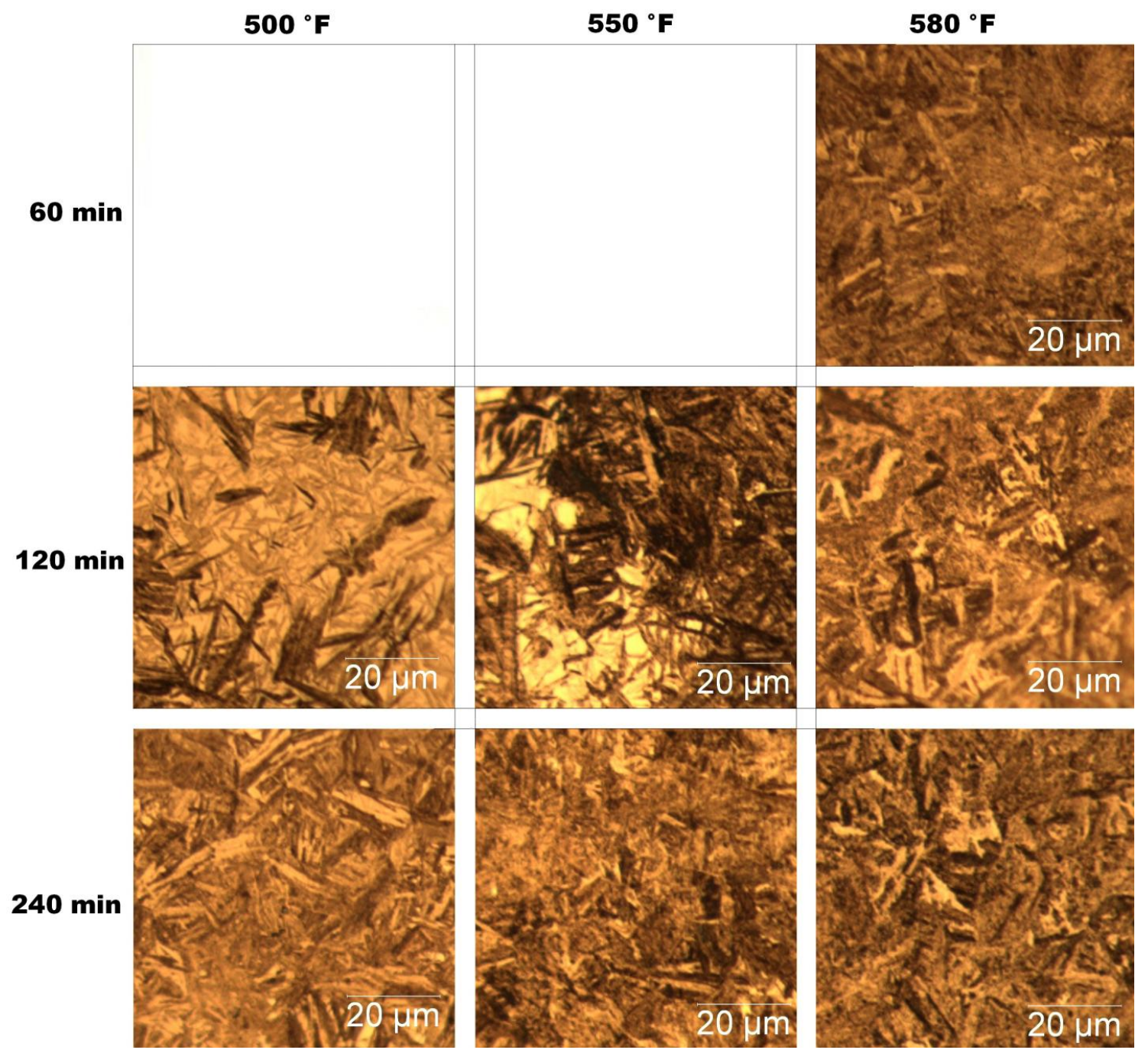

Figure 4.3: Austempered 8822 steel case microstructures

Both case and core microstructures are documented in Figure 4.4 for the quenchand-temper processes in 4320 steel. At both the 650 and $750^{\circ} \mathrm{F}$ tempering temperatures, the case and core microstructures exhibit tempered martensite. The 0.19 weight $\%$ carbon core shows lath martensite, which is formed at compositions below 0.6 weight \% carbon [2]. The transition between plate and lath martensite occurs between 0.6 and 1weight $\%$ carbon. At 0.9 weight $\%$ carbon, the case microstructure exhibits a mix of both lath and plate martensite. The lower carbon content martensite at the core is 
expected to be less brittle than the case martensite. For toughness testing, the core microstructure represents the majority of the fracture surface and most affects the absorbed energy value. Included in Figure 4.4 are the case and core microstructures for 4320 steel austempered at $500^{\circ} \mathrm{F}$ for four hours. The case microstructure shows nearly $100 \%$ bainite. The core microstructure is martensite. Lath martensite is expected due to the low carbon content. The $500^{\circ} \mathrm{F}$ temperature is below the $M_{S}$ temperature; therefore any marteniste present at $500^{\circ} \mathrm{F}$ would be tempered for 4 hours at $500^{\circ} \mathrm{F}$. No data was found on the $M_{f}$ temperature for 8822 steel. As such, any remaining austenite at $500^{\circ} \mathrm{F}$ could either decompose to bainite or quench to martensite at the end of the 4-hour process. The resulting hardness values of the core microstructure are presented in section 4.5.1.
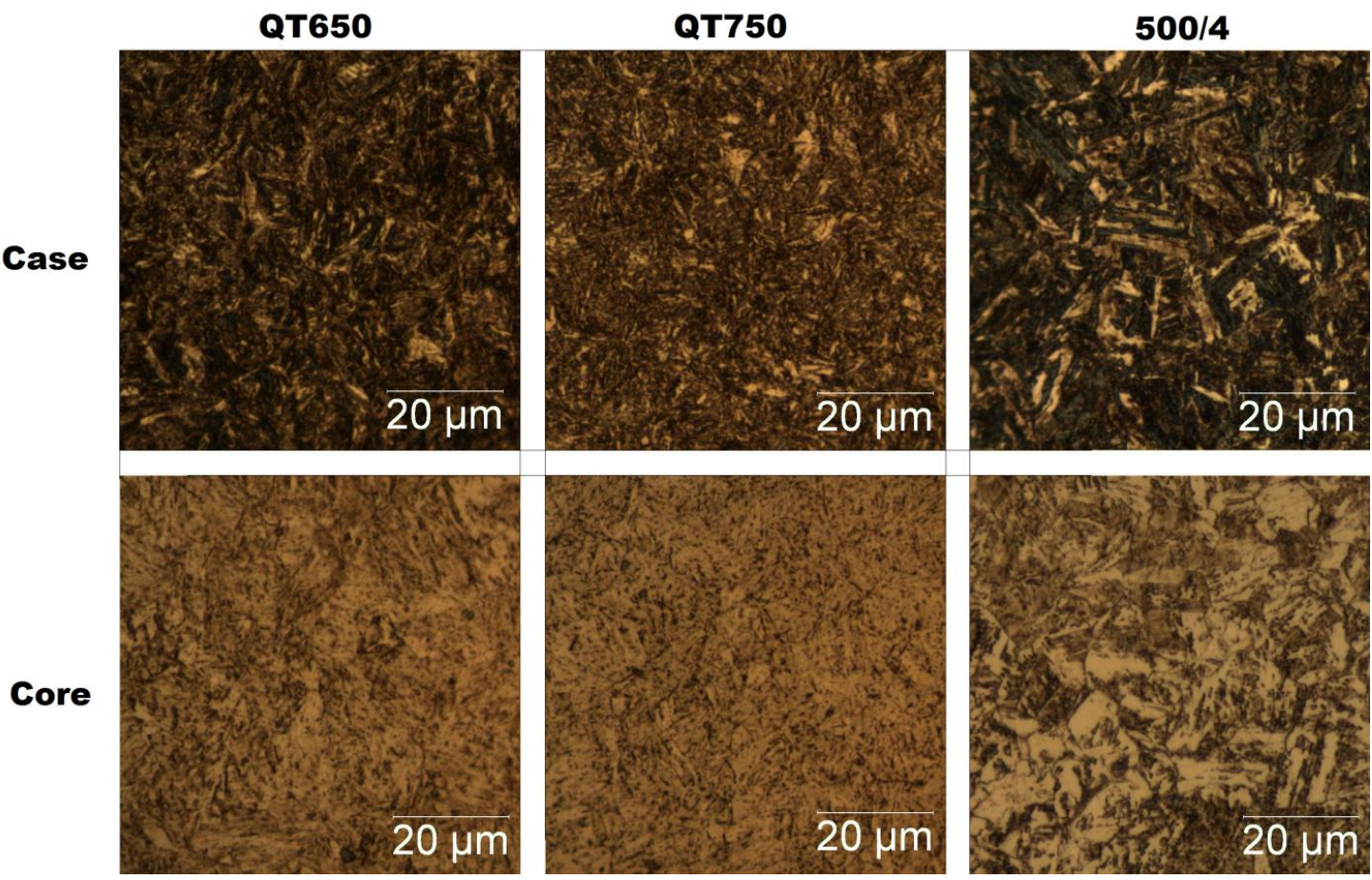

Figure 4.4: Case and core microstructures for 4320 steel. 


\subsection{Distortion}

The results of the Navy C-ring distortion testing are given in section 4.2.1 for size distortion, and 4.2.2 for shape distortion. For each measurement parameter the dimensions used to calculate the distortion are given. All distortion measurements are given as a percentage change regardless of whether the change was positive or negative, in order to highlight the magnitude of change in dimension. The small number of C-rings, two per heat treatment condition, limited any statistical analysis of the data. Nonetheless, an average of the two C-rings is provided for the distortion results; and a standard deviation is calculated using Equation 3.3. The small sample size is based on the preliminary nature of this study, which is meant to provide a proof of concept for future work. Multiple measurement points on each C-ring for the different distortion parameters helped increase the statistical significance of the results.

\subsubsection{Size Distortion}

C-ring size distortion results are given in Tables 4.1 - 4.4, and Figures 4.5 - 4.8. The distortion values were calculated by averaging the values of distortion measured for the two C-ring samples heat treated by the same condition. For the inner (ID) and outer (OD) diameter measurements the percentage change of the maximum values is presented, along with the average change of the three measured values. Thickness distortion is presented as a single value for distortion, calculated by averaging the change in thickness at the 5 measurement locations on the C-ring. Gap width distortion is presented as an average of the change in gap at the three measurement locations. 


\section{Inner Diameter:}

Inner diameter results for the 4320 show that the austempering heat treatments resulted in lower values that the quench-and-temper heat treatment. The same is true of the 8822 results; indeed the 8822 steel exhibited the lowest inner diameter distortion among the steels tested. For the 8620 steel, the inner diameter distortion values varied within the austempering conditions.

The most consistent results for inner diameter distortion occurred for the $580^{\circ} \mathrm{F}$ heat treatments. At this temperature, the distortion decreases monotonically with time for all three steels. For all three steels, the microstructure exhibited was upper bainite. This consistency is not noted for the other temperatures. In relation to the metallurgy of steels, upper bainite is formed more by a diffusion process than a shear transformation. As such, the greater amount of diffusional transformation product with increasing time would correlate to lower distortion. For all materials, the middle-location measurement for inner diameter exhibited less distortion than the top and bottom surface measurements. This lower measurement may demonstrate a possible lack of freedom for expansion and contraction compared to the free surfaces. 
Table 4.1a - Inner Diameter Distortion for 8620 Steel

\begin{tabular}{|c|c|c|c|c|c|c|}
\hline \multirow{2}{*}{ Condition } & \multirow{2}{*}{ Sample \# } & \multicolumn{4}{|c|}{ Inner Diameter Distortion \% } & \multirow{2}{*}{$\begin{array}{l}\text { Condition } \\
\text { Distortion } \\
\end{array}$} \\
\hline & & Top & Middle & Bottom & Average & \\
\hline \multirow{2}{*}{$500 / 2$} & A13 & 0.2898 & 0.2119 & 0.2927 & 0.2648 & \multirow{2}{*}{0.2855} \\
\hline & A14 & 0.3342 & 0.2575 & 0.3270 & 0.3063 & \\
\hline \multirow{2}{*}{$500 / 4$} & $\mathrm{~A} 3$ & 0.3127 & 0.2309 & 0.3026 & 0.2821 & \multirow{2}{*}{0.2727} \\
\hline & A4 & 0.2792 & 0.2237 & 0.2869 & 0.2633 & \\
\hline \multirow{2}{*}{$550 / 2$} & A11 & 0.1809 & 0.1048 & 0.1623 & 0.1493 & \multirow{2}{*}{0.1591} \\
\hline & A12 & 0.1861 & 0.1243 & 0.1962 & 0.1689 & \\
\hline \multirow{2}{*}{$550 / 4$} & A5 & 0.2529 & 0.1948 & 0.2696 & 0.2391 & \multirow{2}{*}{0.2443} \\
\hline & A6 & 0.2609 & 0.2084 & 0.2791 & 0.2495 & \\
\hline \multirow{2}{*}{$580 / 1$} & A7 & 0.3251 & 0.2614 & 0.3301 & 0.3055 & \multirow{2}{*}{0.2861} \\
\hline & A8 & 0.2953 & 0.2221 & 0.2827 & 0.2667 & \\
\hline \multirow{2}{*}{$580 / 2$} & A9 & 0.1823 & 0.1431 & 0.1895 & 0.1716 & \multirow{2}{*}{0.2040} \\
\hline & A10 & 0.2645 & 0.1938 & 0.2510 & 0.2364 & \\
\hline \multirow{2}{*}{$580 / 4$} & A1 & 0.2240 & 0.1575 & 0.2294 & 0.2036 & \multirow{2}{*}{0.1863} \\
\hline & $\mathrm{A} 2$ & 0.1940 & 0.1318 & 0.1810 & 0.1689 & \\
\hline \multirow{2}{*}{ QT650 } & A17 & 0.1401 & 0.0356 & 0.1568 & 0.1108 & \multirow{2}{*}{0.1362} \\
\hline & A18 & 0.2362 & 0.1022 & 0.1464 & 0.1616 & \\
\hline \multirow{2}{*}{ QT750 } & A15 & 0.2321 & 0.1234 & 0.2358 & 0.1971 & \multirow{2}{*}{0.2741} \\
\hline & A16 & 0.3473 & 0.2889 & 0.4173 & 0.3512 & \\
\hline
\end{tabular}


Table 4.1b - Inner Distortion for 8822 Steel

\begin{tabular}{|c|c|c|c|c|c|c|}
\hline \multirow{2}{*}{ Condition } & \multirow{2}{*}{ Sample \# } & \multicolumn{4}{|c|}{ Inner Diameter Distortion \% } & \multirow{2}{*}{$\begin{array}{l}\text { Condition } \\
\text { Distortion } \\
\end{array}$} \\
\hline & & Top & Middle & Bottom & Average & \\
\hline \multirow{2}{*}{$500 / 2$} & B13 & 0.1927 & 0.1552 & 0.1971 & 0.1817 & \multirow{2}{*}{0.1970} \\
\hline & B14 & 0.2213 & 0.1816 & 0.2339 & 0.2123 & \\
\hline \multirow{2}{*}{$500 / 4$} & B3 & 0.1807 & 0.1508 & 0.1822 & 0.1712 & \multirow{2}{*}{0.1603} \\
\hline & B4 & 0.1543 & 0.1303 & 0.1634 & 0.1493 & \\
\hline \multirow{2}{*}{$550 / 2$} & B11 & 0.2405 & 0.1873 & 0.2289 & 0.2189 & \multirow{2}{*}{0.2087} \\
\hline & B12 & 0.2148 & 0.1710 & 0.2094 & 0.1984 & \\
\hline \multirow{2}{*}{$550 / 4$} & B5 & 0.1942 & 0.1587 & 0.2084 & 0.1871 & \multirow{2}{*}{0.1921} \\
\hline & B6 & 0.1952 & 0.1719 & 0.2239 & 0.1970 & \\
\hline \multirow{2}{*}{$580 / 1$} & B7 & 0.2317 & 0.1898 & 0.2294 & 0.2170 & \multirow{2}{*}{0.2570} \\
\hline & B8 & 0.2062 & 0.1854 & 0.4992 & 0.2970 & \\
\hline \multirow{2}{*}{$580 / 2$} & B9 & 0.2059 & 0.1659 & 0.1930 & 0.1883 & \multirow{2}{*}{0.1849} \\
\hline & B10 & 0.1898 & 0.1587 & 0.1961 & 0.1816 & \\
\hline \multirow{2}{*}{$580 / 4$} & B1 & 0.1376 & 0.1020 & 0.1615 & 0.1337 & \multirow{2}{*}{0.1350} \\
\hline & B2 & 0.1558 & 0.1092 & 0.1438 & 0.1363 & \\
\hline \multirow{2}{*}{ QT650 } & B17 & 0.4530 & 0.2464 & 0.3959 & 0.3651 & \multirow{2}{*}{0.3377} \\
\hline & B18 & 0.3967 & 0.2371 & 0.2969 & 0.3102 & \\
\hline \multirow{2}{*}{ QT750 } & B15 & 0.2889 & 0.1904 & 0.3169 & 0.2654 & \multirow{2}{*}{0.3078} \\
\hline & B16 & 0.3772 & 0.2673 & 0.4058 & 0.3501 & \\
\hline
\end{tabular}

Table 4.1c - Inner Distortion for 4320 Steel

\begin{tabular}{|c|c|c|c|c|c|c|}
\hline \multirow{2}{*}{ Condition } & \multirow{2}{*}{ Sample \# } & \multicolumn{4}{|c|}{ Inner Diameter Distortion \% } & \multirow{2}{*}{$\begin{array}{l}\text { Condition } \\
\text { Distortion }\end{array}$} \\
\hline & & Top & Middle & Bottom & Average & \\
\hline \multirow{2}{*}{$500 / 2$} & $\mathrm{C} 13$ & 0.0545 & 0.0009 & 0.0648 & 0.0401 & \multirow{2}{*}{0.0951} \\
\hline & $\mathrm{C} 14$ & 0.1746 & 0.1145 & 0.1611 & 0.1501 & \\
\hline \multirow{2}{*}{$500 / 4$} & $\mathrm{C} 3$ & 0.1130 & 0.0690 & 0.1153 & 0.0991 & \multirow{2}{*}{0.0867} \\
\hline & $\mathrm{C} 4$ & 0.0986 & 0.0384 & 0.0860 & 0.0744 & \\
\hline \multirow{2}{*}{$550 / 2$} & $\mathrm{C} 11$ & 0.0867 & 0.0589 & 0.0889 & 0.0782 & \multirow[b]{2}{*}{0.0881} \\
\hline & $\mathrm{C} 12$ & 0.1170 & 0.0668 & 0.1103 & 0.0980 & \\
\hline \multirow{2}{*}{$550 / 4$} & $\mathrm{C} 5$ & 0.1100 & 0.0920 & 0.1333 & 0.1118 & \multirow{2}{*}{0.0916} \\
\hline & C6 & 0.0929 & 0.0400 & 0.0813 & 0.0714 & \\
\hline \multirow{2}{*}{$580 / 1$} & $\mathrm{C} 7$ & 0.1383 & 0.1012 & 0.1404 & 0.1266 & \multirow{2}{*}{0.0846} \\
\hline & $\mathrm{C} 8$ & 0.0674 & 0.0148 & 0.0457 & 0.0426 & \\
\hline \multirow{2}{*}{$580 / 2$} & C9 & 0.0812 & 0.0415 & 0.0941 & 0.0723 & \multirow[b]{2}{*}{0.0727} \\
\hline & $\mathrm{C} 10$ & 0.0949 & 0.0343 & 0.0902 & 0.0731 & \\
\hline \multirow{2}{*}{$580 / 4$} & $\mathrm{C} 1$ & 0.0833 & 0.0139 & 0.0731 & 0.0568 & \multirow{2}{*}{0.0464} \\
\hline & $\mathrm{C} 2$ & 0.0434 & 0.0003 & 0.0642 & 0.0360 & \\
\hline \multirow{2}{*}{ QT650 } & $\mathrm{C} 17$ & 0.2835 & 0.1355 & 0.1900 & 0.2030 & \multirow{2}{*}{0.1589} \\
\hline & $\mathrm{C} 18$ & 0.1587 & 0.0236 & 0.1622 & 0.1149 & \\
\hline \multirow{2}{*}{ QT750 } & $\mathrm{C} 15$ & 0.2328 & 0.0762 & 0.2558 & 0.1882 & \multirow{2}{*}{0.2106} \\
\hline & $\mathrm{C} 16$ & 0.3290 & 0.1267 & 0.2435 & 0.2330 & \\
\hline
\end{tabular}




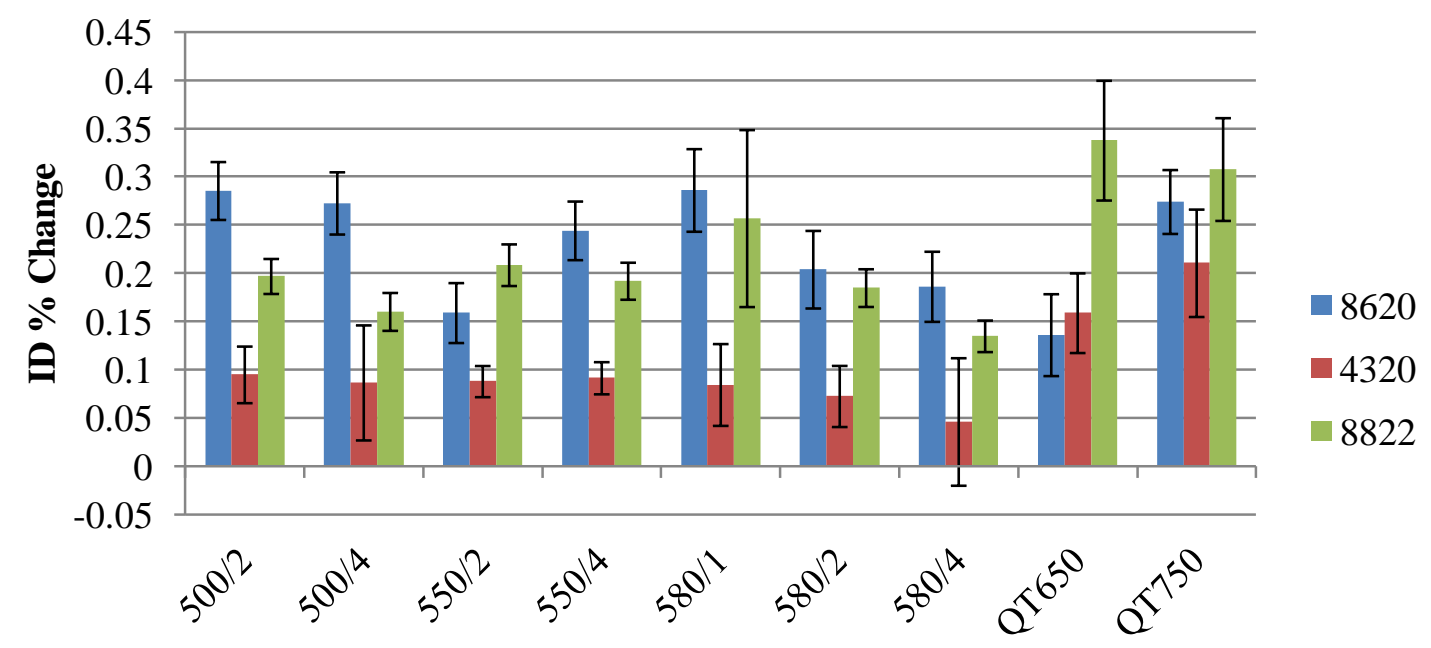

Condition

Figure 4.5: Inner diameter distortion.

\section{Outer Diameter:}

Outer diameter distortion measurements for both 4320 and 8822 steel showed austempering resulted in less distortion than quench-and-tempering. At $550{ }^{\circ} \mathrm{F}, 8620$ steel had austempered distortion values which were similar to those found in quench and tempering. For other temperatures, the 8620 distortion values for austempering were lower than those of the quench-and-tempering processes. For all temperatures, 8620 steel exhibited less distortion with increased time. This trend was not seen with the other two materials. As such, the argument for diffusional versus shear transformation would appear incomplete. The change from a $650^{\circ} \mathrm{F}$ to $750^{\circ} \mathrm{F}$ temper decreased the outer diameter distortion in the 4320 and 8822 steels; it increased the distortion in the 8620 steel. 
Table 4.2a - Outer Distortion for 8620 Steel

\begin{tabular}{|c|c|c|c|c|c|c|}
\hline \multirow{2}{*}{ Condition } & \multirow{2}{*}{ Sample \# } & \multicolumn{4}{|c|}{ Outer Diameter Distortion \% } & \multirow{2}{*}{$\begin{array}{l}\text { Condition } \\
\text { Distortion } \\
\end{array}$} \\
\hline & & Top & Middle & Bottom & Average & \\
\hline \multirow{2}{*}{$500 / 2$} & A13 & 0.1813 & 0.1909 & 0.1835 & 0.1852 & \multirow{2}{*}{0.1909} \\
\hline & A14 & 0.1991 & 0.1940 & 0.1963 & 0.1965 & \\
\hline \multirow{2}{*}{$500 / 4$} & A3 & 0.1848 & 0.1747 & 0.1810 & 0.1802 & \multirow{2}{*}{0.1746} \\
\hline & A4 & 0.1689 & 0.1676 & 0.1707 & 0.1690 & \\
\hline \multirow{2}{*}{$550 / 2$} & A11 & 0.1890 & 0.1793 & 0.1743 & 0.1809 & \multirow{2}{*}{0.2420} \\
\hline & A12 & 0.2051 & 0.3414 & 0.3631 & 0.3032 & \\
\hline \multirow{2}{*}{$550 / 4$} & A5 & 0.2076 & 0.4133 & 0.2330 & 0.2847 & \multirow{2}{*}{0.2332} \\
\hline & A6 & 0.1860 & 0.1794 & 0.1799 & 0.1818 & \\
\hline \multirow{2}{*}{$580 / 1$} & A7 & 0.1927 & 0.1925 & 0.2030 & 0.1961 & \multirow{2}{*}{0.2048} \\
\hline & A8 & 0.2092 & 0.2171 & 0.2143 & 0.2135 & \\
\hline \multirow{2}{*}{$580 / 2$} & A9 & 0.1550 & 0.1556 & 0.1853 & 0.1653 & \multirow{2}{*}{0.1829} \\
\hline & A10 & 0.1994 & 0.1925 & 0.2096 & 0.2005 & \\
\hline \multirow{2}{*}{$580 / 4$} & A1 & 0.1531 & 0.1521 & 0.1670 & 0.1574 & \multirow{2}{*}{0.1551} \\
\hline & A2 & 0.1524 & 0.1524 & 0.1536 & 0.1528 & \\
\hline \multirow{2}{*}{ QT650 } & A17 & 0.1831 & 0.2031 & 0.2123 & 0.1995 & \multirow{2}{*}{0.2073} \\
\hline & A18 & 0.2111 & 0.2126 & 0.2215 & 0.2150 & \\
\hline \multirow{2}{*}{ QT750 } & A15 & 0.2341 & 0.2390 & 0.2394 & 0.2375 & \multirow{2}{*}{0.2563} \\
\hline & A16 & 0.2516 & 0.2718 & 0.3018 & 0.2751 & \\
\hline
\end{tabular}

Table 4.2b - Outer Distortion for 8822 Steel

\begin{tabular}{|c|c|c|c|c|c|c|}
\hline \multirow[b]{2}{*}{ Condition } & \multirow{2}{*}{ Sample \# } & \multicolumn{4}{|c|}{ Outer Diameter Distortion \% } & \multirow{2}{*}{$\begin{array}{l}\text { Condition } \\
\text { Distortion }\end{array}$} \\
\hline & & Top & Middle & Bottom & Average & \\
\hline \multirow{2}{*}{$500 / 2$} & B13 & 0.1626 & 0.1669 & 0.1445 & 0.1580 & \multirow{2}{*}{0.1627} \\
\hline & B14 & 0.1600 & 0.1781 & 0.1643 & 0.1675 & \\
\hline \multirow{2}{*}{$500 / 4$} & B3 & 0.1401 & 0.1464 & 0.1425 & 0.1430 & \multirow{2}{*}{0.1435} \\
\hline & B4 & 0.1340 & 0.1502 & 0.1476 & 0.1439 & \\
\hline \multirow{2}{*}{$550 / 2$} & B11 & 0.1678 & 0.1755 & 0.1556 & 0.1663 & \multirow{2}{*}{0.1652} \\
\hline & B12 & 0.1566 & 0.1767 & 0.1588 & 0.1641 & \\
\hline \multirow{2}{*}{$550 / 4$} & B5 & 0.1474 & 0.1570 & 0.1476 & 0.1507 & \multirow{2}{*}{0.1658} \\
\hline & B6 & 0.1810 & 0.1773 & 0.1846 & 0.1810 & \\
\hline \multirow{2}{*}{$580 / 1$} & B7 & 0.2188 & 0.2161 & 0.2098 & 0.2149 & \multirow{2}{*}{0.1868} \\
\hline & B8 & 0.1641 & 0.1650 & 0.1471 & 0.1587 & \\
\hline \multirow{2}{*}{$580 / 2$} & B9 & 0.1423 & 0.1419 & 0.1287 & 0.1376 & \multirow{2}{*}{0.1343} \\
\hline & B10 & 0.1289 & 0.1360 & 0.1279 & 0.1309 & \\
\hline \multirow{2}{*}{$580 / 4$} & B1 & 0.1242 & 0.1442 & 0.1269 & 0.1318 & \multirow{2}{*}{0.1350} \\
\hline & B2 & 0.1381 & 0.1511 & 0.1259 & 0.1383 & \\
\hline \multirow{2}{*}{ QT650 } & B17 & 0.2471 & 0.2348 & 0.2682 & 0.2500 & \multirow{2}{*}{0.2301} \\
\hline & B18 & 0.2104 & 0.2068 & 0.2135 & 0.2102 & \\
\hline \multirow{2}{*}{ QT750 } & B15 & 0.1701 & 0.1797 & 0.1622 & 0.1707 & \multirow{2}{*}{0.2026} \\
\hline & B16 & 0.2367 & 0.2194 & 0.2476 & 0.2346 & \\
\hline
\end{tabular}


Table 4.2c - Outer Distortion for 4320 Steel

\begin{tabular}{|c|c|c|c|c|c|c|}
\hline \multirow{2}{*}{ Condition } & \multirow{2}{*}{ Sample \# } & \multicolumn{4}{|c|}{ Outer Diameter Distortion \% } & \multirow{2}{*}{$\begin{array}{l}\text { Condition } \\
\text { Distortion }\end{array}$} \\
\hline & & Top & Middle & Bottom & Average & \\
\hline \multirow{2}{*}{$500 / 2$} & $\mathrm{C} 13$ & 0.0811 & 0.0849 & 0.0880 & 0.0847 & \multirow{2}{*}{0.1085} \\
\hline & C14 & 0.1303 & 0.1391 & 0.1277 & 0.1324 & \\
\hline \multirow{2}{*}{$500 / 4$} & $\mathrm{C} 3$ & 0.1161 & 0.1151 & 0.1165 & 0.1159 & \multirow{2}{*}{0.1096} \\
\hline & $\mathrm{C} 4$ & 0.0792 & 0.0882 & 0.1423 & 0.1032 & \\
\hline \multirow{2}{*}{$550 / 2$} & $\mathrm{C} 11$ & 0.1257 & 0.1475 & 0.1275 & 0.1336 & \multirow{2}{*}{0.1267} \\
\hline & $\mathrm{C} 12$ & 0.1156 & 0.1272 & 0.1168 & 0.1199 & \\
\hline \multirow{2}{*}{$550 / 4$} & $\mathrm{C} 5$ & 0.1682 & 0.1736 & 0.1829 & 0.1749 & \multirow{2}{*}{0.1810} \\
\hline & C6 & 0.1959 & 0.1787 & 0.1869 & 0.1872 & \\
\hline \multirow{2}{*}{$580 / 1$} & $\mathrm{C} 7$ & 0.1365 & 0.1403 & 0.1311 & 0.1360 & \multirow{2}{*}{0.1093} \\
\hline & $\mathrm{C} 8$ & 0.0865 & 0.0860 & 0.0754 & 0.0826 & \\
\hline \multirow{2}{*}{$580 / 2$} & C9 & 0.1087 & 0.1138 & 0.1058 & 0.1094 & \multirow{2}{*}{0.1003} \\
\hline & $\mathrm{C} 10$ & 0.0885 & 0.0945 & 0.0905 & 0.0912 & \\
\hline \multirow{2}{*}{$580 / 4$} & $\mathrm{C} 1$ & 0.1097 & 0.1125 & 0.1133 & 0.1118 & \multirow{2}{*}{0.1078} \\
\hline & $\mathrm{C} 2$ & 0.0949 & 0.1046 & 0.1121 & 0.1039 & \\
\hline \multirow{2}{*}{ QT650 } & $\mathrm{C} 17$ & 0.1884 & 0.2005 & 0.1744 & 0.1878 & \multirow{2}{*}{0.2037} \\
\hline & $\mathrm{C} 18$ & 0.2172 & 0.2366 & 0.2052 & 0.2197 & \\
\hline \multirow{2}{*}{ QT750 } & $\mathrm{C} 15$ & 0.1574 & 0.1944 & 0.2154 & 0.1891 & \multirow{2}{*}{0.1921} \\
\hline & C16 & 0.1975 & 0.2024 & 0.1853 & 0.1951 & \\
\hline
\end{tabular}

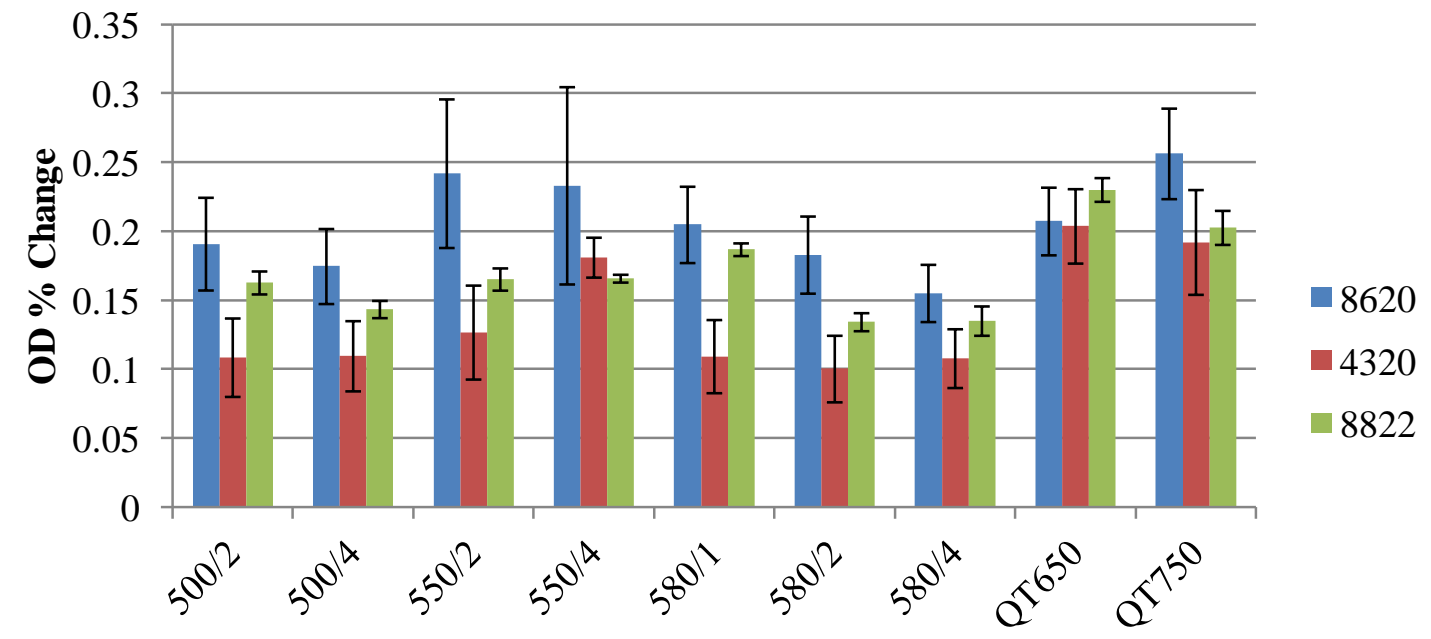

Condition

Figure 4.6: Outer diameter distortion. 


\section{Thickness:}

Thickness results for all three materials revealed that austempering produced less distortion than quench-and-tempering. For all three steels the $500{ }^{\circ} \mathrm{F}$ and $550{ }^{\circ} \mathrm{F}$ austempering temperatures exhibited decreased the distortion levels with increasing time. The opposite was true with the $580{ }^{\circ} \mathrm{F}$ temperature, where distortion increased with increased austempering time regardless of material.

Table 4.3a - Thickness Distortion for 8620 Steel

\begin{tabular}{|c|c|c|c|c|}
\hline \multicolumn{2}{|c|}{ Sample \# } & Distortion & Average & $\sigma / 2$ \\
\hline \multirow{2}{*}{$500 / 2$} & A13 & 0.0471 & \multirow{2}{*}{0.0721} & \multirow{2}{*}{0.0177} \\
\hline & A14 & 0.097 & & \\
\hline \multirow{2}{*}{$500 / 4$} & A3 & 0.0203 & \multirow{2}{*}{0.0314} & \multirow{2}{*}{0.0078} \\
\hline & A4 & 0.0425 & & \\
\hline \multirow{2}{*}{$550 / 2$} & A11 & 0.1295 & \multirow{2}{*}{0.1220} & \multirow{2}{*}{0.0053} \\
\hline & A12 & 0.1144 & & \\
\hline \multirow{2}{*}{$550 / 4$} & A5 & 0.073 & \multirow{2}{*}{0.0560} & \multirow{2}{*}{0.0120} \\
\hline & A6 & 0.039 & & \\
\hline \multirow{2}{*}{$580 / 1$} & A7 & 0.0712 & \multirow{2}{*}{0.0395} & \multirow{2}{*}{0.0224} \\
\hline & A8 & 0.0079 & & \\
\hline \multirow{2}{*}{$580 / 2$} & A9 & 0.099 & \multirow{2}{*}{0.0732} & \multirow{2}{*}{0.0182} \\
\hline & A10 & 0.0474 & & \\
\hline \multirow{2}{*}{$580 / 4$} & $\mathrm{~A} 1$ & 0.1102 & \multirow{2}{*}{0.0803} & \multirow{2}{*}{0.0212} \\
\hline & $\mathrm{A} 2$ & 0.0503 & & \\
\hline \multirow{2}{*}{ QT650 } & A17 & 0.1099 & \multirow{2}{*}{0.1557} & \multirow{2}{*}{0.0324} \\
\hline & A18 & 0.2015 & & \\
\hline \multirow{2}{*}{ QT750 } & A15 & 0.094 & \multirow{2}{*}{0.1841} & \multirow{2}{*}{0.0637} \\
\hline & A16 & 0.2742 & & \\
\hline
\end{tabular}


Table 4.3b - Thickness Distortion for 8822 Steel

\begin{tabular}{|c|c|c|c|c|}
\hline \multicolumn{2}{|c|}{ Sample \# } & Distortion & Average & $\sigma / 2$ \\
\hline \multirow{2}{*}{$500 / 2$} & B13 & 0.0499 & \multirow{2}{*}{0.0480} & \multirow{2}{*}{0.0171} \\
\hline & B14 & 0.0462 & & \\
\hline \multirow{2}{*}{$500 / 4$} & B3 & 0.0098 & \multirow{2}{*}{0.0326} & \multirow{2}{*}{0.0160} \\
\hline & B4 & 0.0554 & & \\
\hline \multirow{2}{*}{$550 / 2$} & B11 & 0.0663 & \multirow{2}{*}{0.0701} & \multirow{2}{*}{0.0272} \\
\hline & B12 & 0.0740 & & \\
\hline \multirow{2}{*}{$550 / 4$} & B5 & 0.0461 & \multirow{2}{*}{0.0534} & \multirow{2}{*}{0.0188} \\
\hline & B6 & 0.0607 & & \\
\hline \multirow{2}{*}{$580 / 1$} & B7 & 0.0331 & \multirow{2}{*}{0.0372} & \multirow{2}{*}{0.0431} \\
\hline & B8 & 0.0413 & & \\
\hline \multirow{2}{*}{$580 / 2$} & B9 & 0.0504 & \multirow{2}{*}{0.0431} & \multirow{2}{*}{0.0233} \\
\hline & B10 & 0.0358 & & \\
\hline \multirow{2}{*}{$580 / 4$} & B1 & 0.0882 & \multirow{2}{*}{0.0576} & \multirow{2}{*}{0.0089} \\
\hline & B2 & 0.0271 & & \\
\hline \multirow{2}{*}{ QT650 } & B17 & 0.1267 & \multirow{2}{*}{0.1727} & \multirow{2}{*}{0.0246} \\
\hline & B18 & 0.2188 & & \\
\hline \multirow{2}{*}{ QT750 } & B15 & 0.1195 & \multirow{2}{*}{0.1712} & \multirow{2}{*}{0.0261} \\
\hline & B16 & 0.2229 & & \\
\hline
\end{tabular}

Table 4.3c - Thickness Distortion for 4320 Steel

\begin{tabular}{|c|c|c|c|c|}
\hline \multicolumn{2}{|c|}{ Sample \# } & $\begin{array}{c}\text { Distortion } \\
\%\end{array}$ & Average & $\sigma / 2$ \\
\hline \multirow{2}{*}{$500 / 2$} & $\mathrm{~A} 13$ & 0.0964 & \multirow{2}{*}{0.0922} & \multirow{2}{*}{0.0030} \\
\hline & A14 & 0.0879 & & \\
\hline \multirow{2}{*}{$500 / 4$} & A3 & 0.0793 & \multirow{2}{*}{0.0641} & \multirow{2}{*}{0.0107} \\
\hline & A4 & 0.0490 & & \\
\hline \multirow{2}{*}{$550 / 2$} & A11 & 0.1015 & \multirow{2}{*}{0.1022} & \multirow{2}{*}{0.0005} \\
\hline & A12 & 0.1028 & & \\
\hline \multirow{2}{*}{$550 / 4$} & A5 & 0.0685 & \multirow{2}{*}{0.0717} & \multirow{2}{*}{0.0023} \\
\hline & A6 & 0.0750 & & \\
\hline \multirow{2}{*}{$580 / 1$} & A7 & 0.0078 & \multirow{2}{*}{0.0267} & \multirow{2}{*}{0.0133} \\
\hline & A8 & 0.0455 & & \\
\hline \multirow{2}{*}{$580 / 2$} & A9 & 0.0693 & \multirow{2}{*}{0.0828} & \multirow{2}{*}{0.0096} \\
\hline & A10 & 0.0963 & & \\
\hline \multirow{2}{*}{$580 / 4$} & A1 & 0.0863 & \multirow{2}{*}{0.0959} & \multirow{2}{*}{0.0068} \\
\hline & A2 & 0.1056 & & \\
\hline \multirow{2}{*}{ QT650 } & A17 & 0.1952 & \multirow{2}{*}{0.1909} & \multirow{2}{*}{0.0031} \\
\hline & A18 & 0.1865 & & \\
\hline \multirow{2}{*}{ QT750 } & $\mathrm{A} 15$ & 0.2443 & \multirow{2}{*}{0.2100} & \multirow{2}{*}{0.0243} \\
\hline & A16 & 0.1757 & & \\
\hline
\end{tabular}




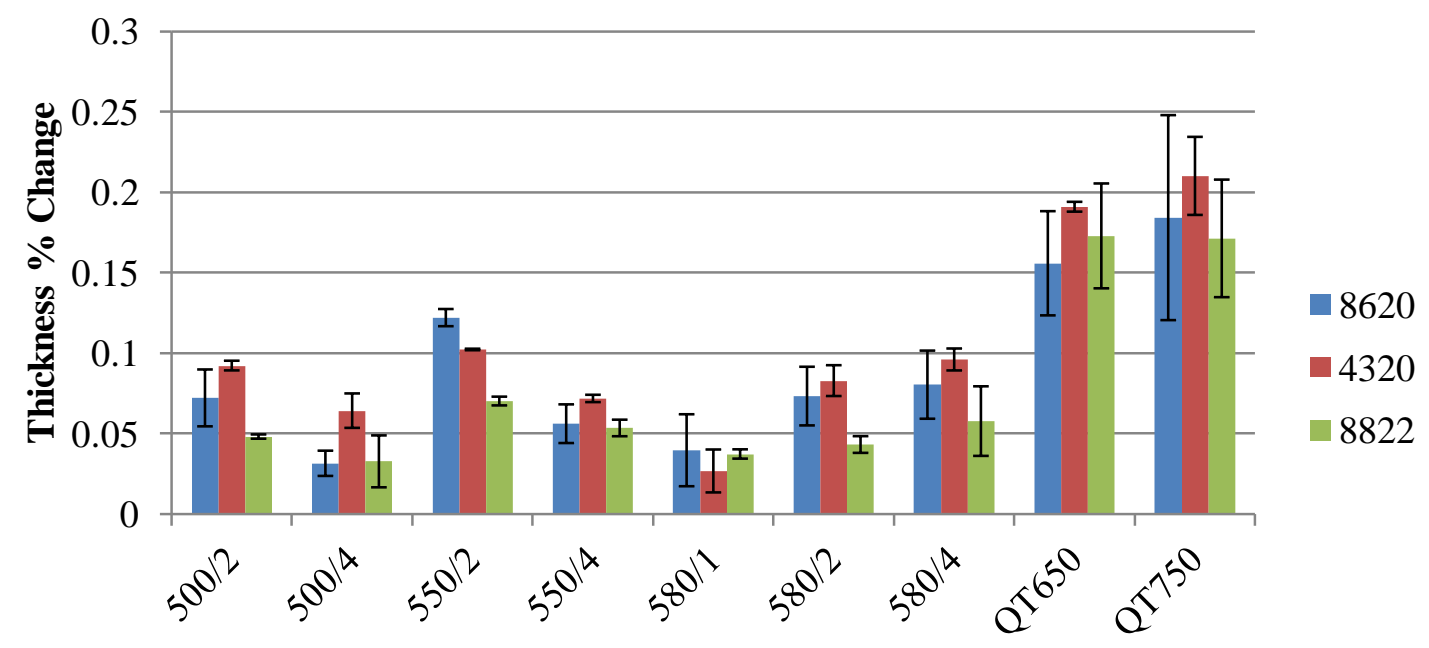

Condition

Figure 4.7: Thickness distortion.

Gap Width:

Gap width measurements for all three materials showed that the quench-andtempered samples produced larger distortion than the austempered conditions. The 8620 had the largest gap width distortion and 4320 the least for all austempering conditions except for 500/4, where 8822 steel had the least distortion. The 500/4 condition for 8822 , however, exhibited the largest variation about the mean within the austempered conditions. All materials exhibited lower distortion with increased austempering time at $500{ }^{\circ} \mathrm{F}$ and $580^{\circ} \mathrm{F}$. This trend was not noted at $500^{\circ} \mathrm{F}$. 
Table 4.4a - Gap Width Distortion for 8620 Steel

\begin{tabular}{|c|c|c|c|c|c|c|c|}
\hline \multicolumn{2}{|c|}{ Sample \# } & $\begin{array}{c}\text { Top } \\
\text { Distortion }\end{array}$ & $\begin{array}{c}\text { Middle } \\
\text { Distortion }\end{array}$ & $\begin{array}{c}\text { Bottom } \\
\text { Distortion }\end{array}$ & $\begin{array}{l}\text { Specimen } \\
\text { \%Change }\end{array}$ & $\begin{array}{l}\text { Parameter } \\
\% \text { Change }\end{array}$ & $\sigma / 2$ \\
\hline \multirow{2}{*}{$500 / 2$} & A13 & 5.2783 & 5.4663 & 5.3809 & 5.3752 & \multirow{2}{*}{5.4663} & \multirow[b]{2}{*}{0.0617} \\
\hline & A14 & 5.5990 & 5.5909 & 5.4825 & 5.5575 & & \\
\hline \multirow{2}{*}{$500 / 4$} & A3 & 4.9797 & 4.9888 & 4.9868 & 4.9 & \multirow{2}{*}{5.0160} & \multirow{2}{*}{0.0855} \\
\hline & $\mathrm{A} 4$ & 3518 & 4.8713 & 4.9 & 5.0 & & \\
\hline \multirow{2}{*}{$550 / 2$} & A11 & 1155 & .0753 & 3.9605 & 4.1 & \multirow{2}{*}{4.0731} & \multirow{2}{*}{0.0318} \\
\hline & A12 & 1178 & 4.0427 & 4.1 & 4.0 & & \\
\hline \multirow{2}{*}{$550 / 4$} & A5 & 7492 & 4.7920 & 4.9 & 4.8440 & \multirow{2}{*}{4.7122} & \multirow{2}{*}{0.0883} \\
\hline & A6 & 4.5184 & 4.5316 & 4.6 & 4.5804 & & \\
\hline \multirow{2}{*}{$580 / 1$} & A7 & 5.8248 & 5.7672 & 5.7 & 5.7761 & \multirow{2}{*}{5.6184} & \multirow[b]{2}{*}{0.0880} \\
\hline & $\mathrm{A} 8$ & 5.4494 & & & & & \\
\hline \multirow{2}{*}{$580 / 2$} & $\mathrm{Ac}^{\mathrm{C}}$ & 3.4316 & & & & \multirow{2}{*}{4.0194} & \multirow{2}{*}{0.3099} \\
\hline & $\mathrm{A} 1$ & 5563 & 4.5915 & & & & \\
\hline \multirow{2}{*}{$580 / 4$} & 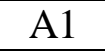 & 2255 & 98 & & 4.2 & \multirow{2}{*}{4.0238} & \multirow{2}{*}{0.1114} \\
\hline & A? & 3106 & 3.7431 & & 3.8 & & \\
\hline \multirow{2}{*}{ QT650 } & A17 & 5.1698 & 5.3723 & 5.3 & 5.2909 & \multirow{2}{*}{5.8267} & \multirow{2}{*}{0.3137} \\
\hline & A1 & 6.6248 & 6.4756 & 5.9 & & & \\
\hline \multirow{2}{*}{ QT750 } & A15 & 6.4891 & 6.6753 & 6.4525 & 6.5390 & \multirow{2}{*}{7.1803} & \multirow{2}{*}{0.3675} \\
\hline & A16 & 7.4820 & 7.8652 & 8.1178 & 7.8217 & & \\
\hline
\end{tabular}


Table 4.4b - Gap Width Distortion for 8822 Steel

\begin{tabular}{|c|c|c|c|c|c|c|c|}
\hline \multicolumn{2}{|c|}{ Sample \# } & $\begin{array}{c}\text { Top } \\
\text { Distortion }\end{array}$ & $\begin{array}{l}\text { Middle } \\
\text { Distortion }\end{array}$ & Bottom & Specimen & Parameter & $\sigma / 2$ \\
\hline \multirow{2}{*}{$500 / 2$} & A13 & 3.3740 & 3.3824 & 3.2721 & 3.3428 & \multirow{2}{*}{3.4669} & \multirow[b]{2}{*}{0.0815} \\
\hline & A14 & 3.5088 & 3.7393 & 3.5245 & 3.5909 & & \\
\hline \multirow{2}{*}{$500 / 4$} & A3 & 3.4656 & 3.0444 & 3.4249 & 3.3117 & \multirow{2}{*}{2.8763} & \multirow{2}{*}{0.6616} \\
\hline & A4 & 1.6535 & 2.9167 & 2.7525 & 2.4409 & & \\
\hline \multirow{2}{*}{$550 / 2$} & A11 & 4.0776 & 4.0211 & 3.7667 & 3.9551 & \multirow[b]{2}{*}{3.7818} & \multirow{2}{*}{0.1110} \\
\hline & A12 & 3.6207 & 3.6766 & 3.5280 & 3.6084 & & \\
\hline \multirow{2}{*}{$550 / 4$} & A5 & 3.5841 & 3.6916 & 3.5783 & 3.6180 & \multirow{2}{*}{3.8730} & \multirow{2}{*}{0.1423} \\
\hline & A6 & 4.0896 & 4.1941 & 4.1001 & 4.1279 & & \\
\hline \multirow{2}{*}{$580 / 1$} & A7 & 3.9677 & 3.9850 & 3.9196 & 3.9574 & \multirow{2}{*}{3.8773} & \multirow{2}{*}{0.0610} \\
\hline & A8 & 3.7772 & 3.9358 & 3.6785 & 3.7971 & & \\
\hline \multirow{2}{*}{$580 / 2$} & A9 & 3.4698 & 3.5327 & 3.4199 & 3.4741 & \multirow{2}{*}{3.3562} & \multirow{2}{*}{0.0700} \\
\hline & A10 & 3.1895 & 3.3111 & 143 & 3.2383 & & \\
\hline \multirow{2}{*}{$580 / 4$} & A1 & 3.1468 & 3.0865 & 2.9720 & 3.0684 & \multirow{2}{*}{3.1796} & \multirow{2}{*}{0.0694} \\
\hline & A2 & 3.2485 & 3.3553 & 3.2685 & 3.2908 & & \\
\hline \multirow{2}{*}{ QT650 } & A17 & 7.3694 & 7.4491 & 7.2680 & 7.3622 & \multirow{2}{*}{6.9373} & \multirow{2}{*}{0.2583} \\
\hline & A18 & 6.7679 & 6.6465 & 6.1227 & 6.5124 & & \\
\hline \multirow{2}{*}{ QT750 } & A15 & 6.6669 & 6.8680 & 6.7232 & 6.7527 & \multirow{2}{*}{6.9621} & \multirow{2}{*}{0.1259} \\
\hline & A16 & 7.1716 & 7.2984 & 7.0448 & 7.1716 & & \\
\hline
\end{tabular}

Table 4.4c - Gap Width Distortion for 4320 Steel

\begin{tabular}{|c|c|c|c|c|c|c|c|}
\hline \multicolumn{2}{|c|}{ Sample \# } & $\begin{array}{c}\text { Top } \\
\text { Distortion }\end{array}$ & $\begin{array}{l}\text { Middle } \\
\text { Distortion }\end{array}$ & $\begin{array}{l}\text { Bottom } \\
\text { Distortion }\end{array}$ & $\begin{array}{l}\text { Specimen } \\
\text { \%Change }\end{array}$ & $\begin{array}{l}\text { Parameter } \\
\% \text { Change }\end{array}$ & $\sigma / 2$ \\
\hline \multirow{2}{*}{$500 /$} & A13 & 2.3964 & 2.5279 & 2.4518 & 2.4587 & \multirow{2}{*}{3.0825} & \multirow{2}{*}{0.3433} \\
\hline & A14 & 3.7439 & 3.7635 & 3.6115 & 3.7063 & & \\
\hline \multirow{2}{*}{$500 / 4$} & A3 & 3.0861 & 3.2283 & 30 & 24 & \multirow{2}{*}{2.7320} & \multirow{2}{*}{0.2219} \\
\hline & A4 & 2.1985 & 2.3071 & 2.5190 & 2. & & \\
\hline \multirow{2}{*}{$550 / 2$} & A11 & 3.2849 & & & & \multirow{2}{*}{3.3185} & \multirow{2}{*}{0.0701} \\
\hline & A12 & 3.2581 & & & & & \\
\hline \multirow{2}{*}{$50 / 4$} & A5 & & & & & \multirow[b]{2}{*}{3.31} & \multirow{2}{*}{0.0731} \\
\hline & A6 & 3.12 & & & & & \\
\hline \multirow{2}{*}{$580 / 1$} & A7 & 3 & 69 & & & & \multirow{2}{*}{0.2930} \\
\hline & A8 & 2.4928 & 2.6270 & 2.3997 & $J$ & & \\
\hline \multirow{2}{*}{$580 / 2$} & A9 & 2.5551 & 2.7220 & 2.5890 & 2.6220 & \multirow{2}{*}{2.724} & \multirow{2}{*}{0.0666} \\
\hline & A10 & 2.8371 & 2.8926 & 2.7509 & 2.8269 & & \\
\hline \multirow{2}{*}{$580 / 4$} & A1 & 2.5976 & 2.6812 & 2.5304 & 2.6031 & \multirow{2}{*}{2.4926} & \multirow{2}{*}{0.0699} \\
\hline & A2 & 2. & & & & & \\
\hline \multirow{2}{*}{ QT650 } & A17 & 7.402 & & & & \multirow{2}{*}{7.0565} & \multirow{2}{*}{0.1292} \\
\hline & A18 & 6.97 & & & & & \\
\hline \multirow{2}{*}{ QT750 } & A15 & 7.472 & & & & \multirow{2}{*}{7.53} & \multirow{2}{*}{0.0974} \\
\hline & A16 & 7.8119 & 7.6772 & 7.2467 & 7.5786 & & \\
\hline
\end{tabular}




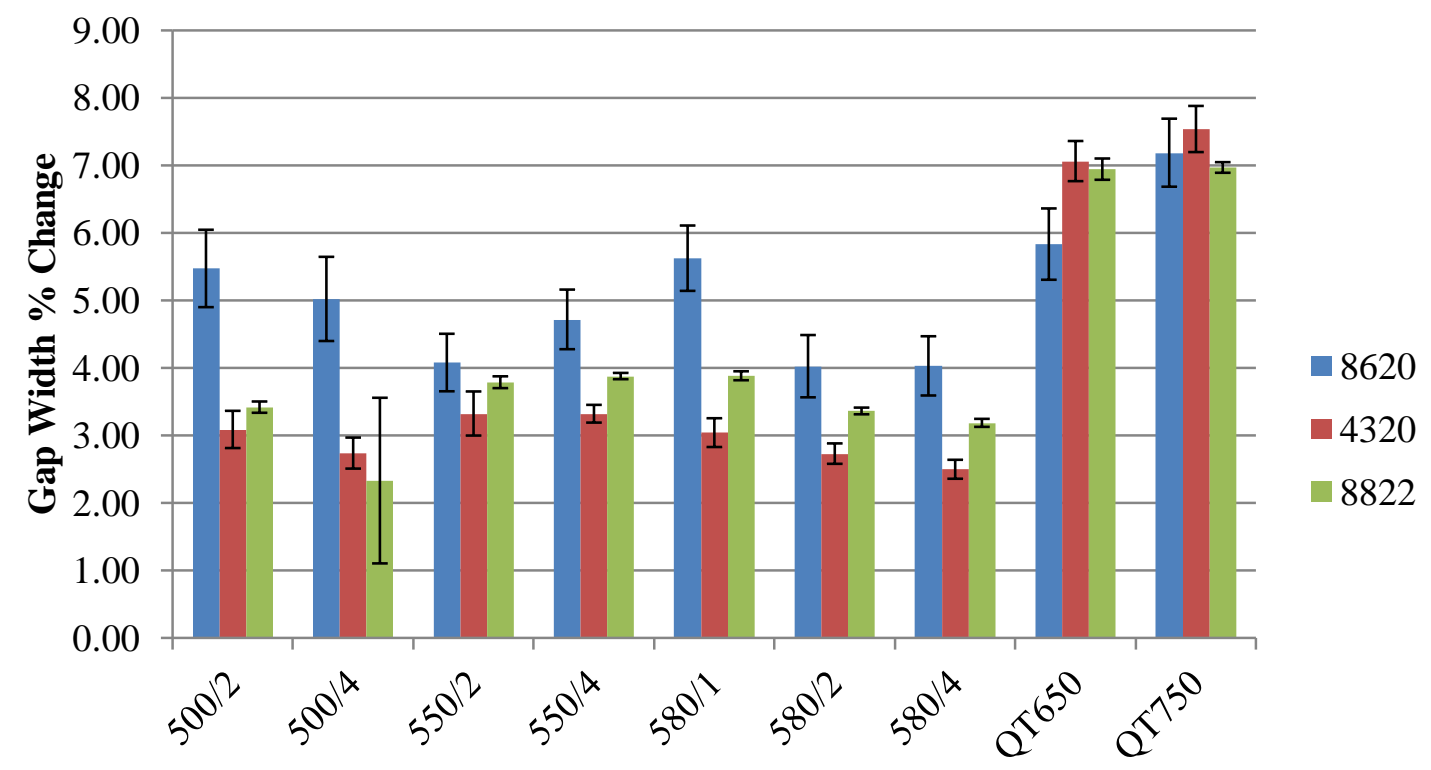

Condition

Figure 4.8: Gap width distortion.

\section{Summary of Size Distortion:}

Size distortions results can be summarized as follows. 1) For ID, OD, and gap width size distortions, 4320 steel had the least distortion for nearly all austempering conditions. For thickness distortion, it was often associated with the highest distortion among the three steels. 8822 consistently had less distortion that 8620 when austempered.

2) The austempering heat treatments consistently produced less distortion than the quench-and-tempering heat treatments. This decreased distortion was attributed to the phase change to bainite being a smaller volume change than the transformation to martensite. 


\subsubsection{Shape Distortion}

Shape distortion results, flatness, cylindricity, and roundness, are given as a percentage in Tables 4.5 - 4.7a and Figures 4.9 -4.11, while measurement values are given in Tables $4.5-4.7 \mathrm{~b}$. Shape distortions showed a larger percentage change compared to the size distortion measurements. This increased change occurs because the initial measurement for shape distortions are small compared to the initial measurements found in the size distortions. Therefore, any change in shape will be reflected as a larger percentage change.

Flatness:

The 8822 steel results had flatness values several times lower than the values for 8620 and 4320 steel. These results were consistent for both austemper and quench-andtemper processes. 8822 steel also had little error distribution relative to the other two materials. The 8620 and 4320 yielded similar flatness results. The quench-and-tempering processes produced considerably more than two times the flatness distortion of the austempering conditions. There was no pattern observed in terms of the effects of time and temperature on distortion. 
Table 4.5a - Flatness Distortion

\begin{tabular}{|c|c|c|c|}
\hline \multicolumn{4}{|c|}{ Flatness \% Change } \\
\hline \multirow{2}{*}{ Condition } & 8620 & 4320 & 8822 \\
\hline $500 / 2$ & $75.6 \pm 15$ & $101.7 \pm 45$ & $28.2 \pm 2$ \\
\hline $500 / 4$ & $52.4 \pm 25$ & $83.7 \pm 28$ & $26.2 \pm 3$ \\
\hline $550 / 2$ & $87.2 \pm 33$ & $88.0 \pm 2$ & $24.7 \pm 7$ \\
\hline $550 / 4$ & $34.6 \pm 18$ & $84.3 \pm 8$ & $25.3 \pm 8$ \\
\hline $580 / 1$ & $82.9 \pm 1$ & $72.9 \pm 6$ & $13.0 \pm 0$ \\
\hline $580 / 2$ & $77.6 \pm 17$ & $32.0 \pm 0$ & $14.7 \pm 2$ \\
\hline $580 / 4$ & $59.1 \pm 4$ & $57.3 \pm 7$ & $4.3 \pm 1$ \\
\hline QT650/1 & $223.2 \pm 69$ & $233.6 \pm 12$ & $84.7 \pm 12$ \\
\hline QT750/1 & $184.7 \pm 17$ & $251.8 \pm 46$ & $81.9 \pm 34$ \\
\hline
\end{tabular}

Table 4.5b - Flatness Distortion

\begin{tabular}{|c|c|c|c|}
\hline \multicolumn{4}{|c|}{ Flatness Change (mm) } \\
\hline \multirow{2}{*}{ Condition } & 8620 & 4320 & 8822 \\
\hline $500 / 2$ & 0.0076 & 0.0065 & 0.0064 \\
\hline $500 / 4$ & 0.0053 & 0.0088 & 0.0069 \\
\hline $550 / 2$ & 0.0069 & 0.0061 & 0.0051 \\
\hline $550 / 4$ & 0.0034 & 0.0060 & 0.0047 \\
\hline $580 / 1$ & 0.0080 & 0.0062 & 0.0042 \\
\hline $580 / 2$ & 0.0063 & 0.0040 & 0.0037 \\
\hline $580 / 4$ & 0.0057 & 0.0041 & 0.0015 \\
\hline QT650 & 0.0207 & 0.0196 & 0.0148 \\
\hline QT750 & 0.0189 & 0.0214 & 0.0147 \\
\hline
\end{tabular}




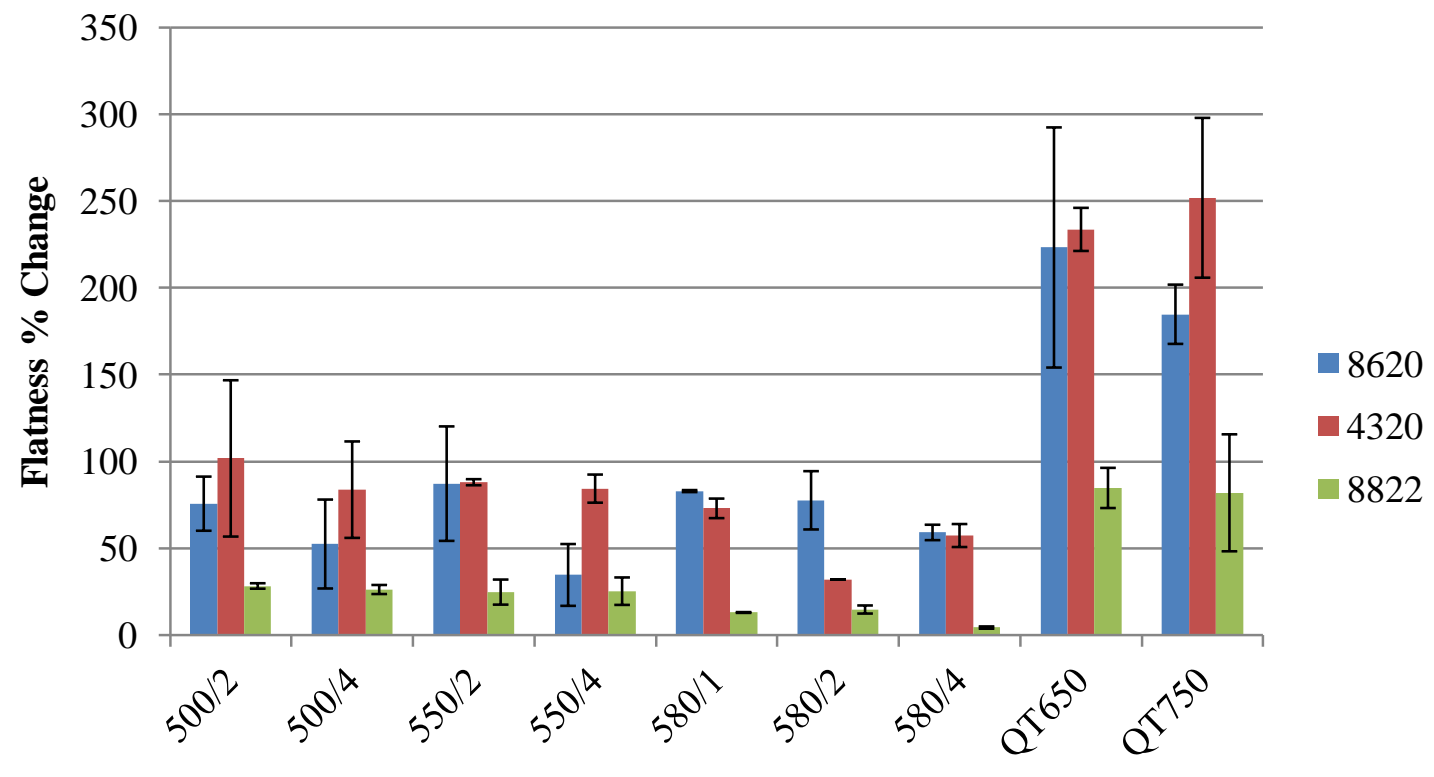

Condition

Figure 4.9: Flatness distortion.

\section{Roundness:}

Roundness data exhibits the opposite behaviour of flatness. For each heat treatment parameter, the 8822 steel had the largest distortion. The quenched and tempered samples had, interestingly, distortions that fell in the middle range when compared to the austempered conditions. The 8822 results showed that with increased time at a given temperature the roundness distortion is reduced. The reported error for roundness was relatively small compared to the magnitudes of change found. 
Table 4.6a - Roundness Distortion

\begin{tabular}{|c|c|c|c|}
\hline \multicolumn{4}{|c|}{ Roundness \% Change } \\
\hline & 8620 & 4320 & 8822 \\
\hline $500 / 2$ & $4.74 \pm 2.0$ & $11.64 \pm 1.7$ & $229.89 \pm 9.7$ \\
\hline $500 / 4$ & $11.44 \pm 7.2$ & $26.38 \pm 3.0$ & $128.65 \pm 13.7$ \\
\hline $550 / 2$ & $7.76 \pm 0.9$ & $19.74 \pm 2.2$ & $212.62 \pm 8.5$ \\
\hline $550 / 4$ & $1.43 \pm 1.8$ & $20.86 \pm 5.2$ & $63.53 \pm 6.2$ \\
\hline $580 / 1$ & $7.86 \pm 3.7$ & $7.70 \pm 3.0$ & $248.56 \pm 7.2$ \\
\hline $580 / 2$ & $1.59 \pm 2.7$ & $1.72 \pm 4.2$ & $144.75 \pm 13.1$ \\
\hline $580 / 4$ & $12.21 \pm 3.0$ & $5.46 \pm 7.1$ & $81.58 \pm 5.0$ \\
\hline QT650 & $13.59 \pm 2.8$ & $19.81 \pm 3.6$ & $150.77 \pm 10.4$ \\
\hline QT750 & $10.57 \pm 3.0$ & $3.35 \pm 4.7$ & $200.25 \pm 6.8$ \\
\hline
\end{tabular}

Table 4.6b - Roundness Distortion

\begin{tabular}{|c|c|c|c|}
\hline \multicolumn{4}{|c|}{ Roundness Change (mm) } \\
\hline Condition & 8620 & 4320 & 8822 \\
\hline $500 / 2$ & 0.0050 & 0.0098 & 0.0284 \\
\hline $500 / 4$ & 0.0113 & 0.0166 & 0.0188 \\
\hline $550 / 2$ & 0.0075 & 0.0105 & 0.0267 \\
\hline $550 / 4$ & 0.0015 & 0.0115 & 0.0070 \\
\hline $580 / 1$ & 0.0081 & 0.0060 & 0.0327 \\
\hline $580 / 2$ & 0.0014 & 0.0014 & 0.0143 \\
\hline $580 / 4$ & 0.0084 & 0.0043 & 0.0132 \\
\hline QT650 & 0.0125 & 0.0146 & 0.0225 \\
\hline QT750 & 0.0097 & 0.0028 & 0.0210 \\
\hline
\end{tabular}




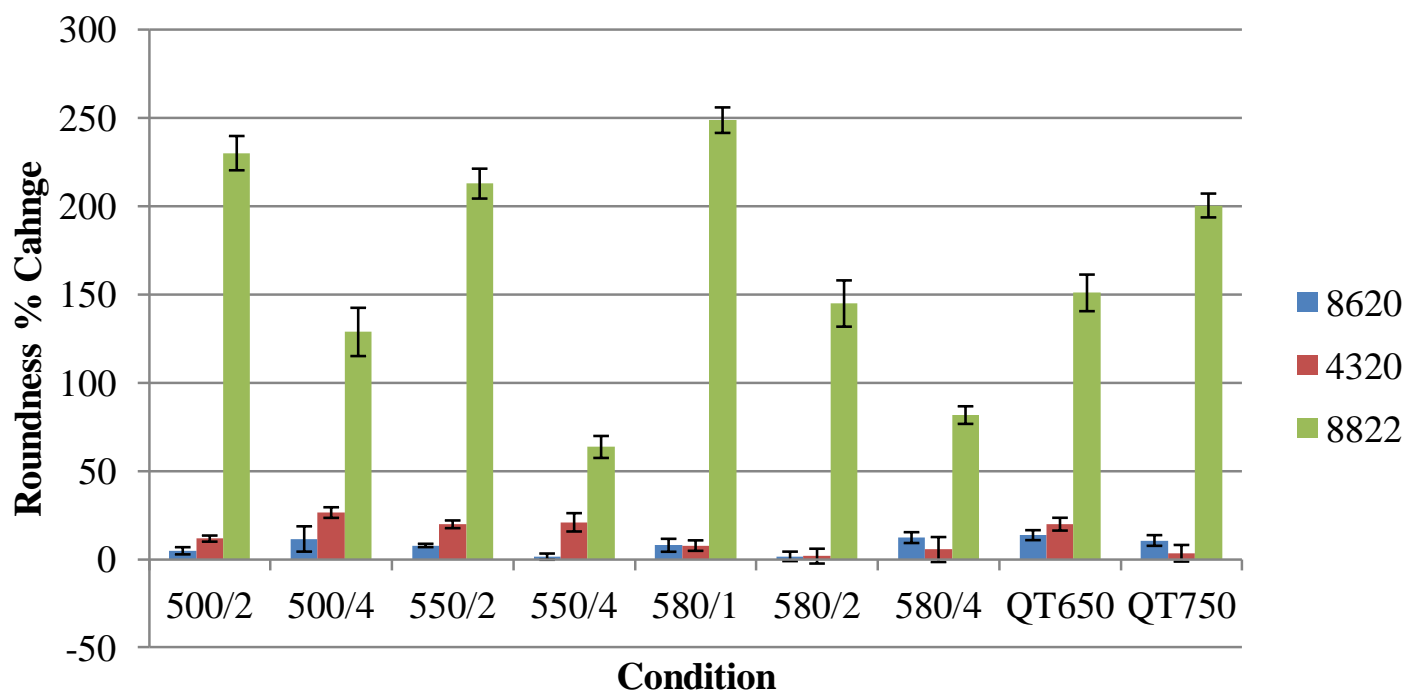

Figure 4.10: Roundness distortion.

Cylindricity:

As with roundness, the cylindricity results showed that the 8822 again had the largest distortions. However, the 580/2 and 580/4 conditions for the 8822 steel are in line with the other two steels. Unlike the roundness measurements, the error associated with cylindricity could be relatively large. With the exception of the 550/4 condition for 4320 and the 580/2 condition for 8620 , the distortion values for austempered conditions were lower than those found for the quenched-and-tempered conditions.

Table 4.7a - Cylindricity Distortion

\begin{tabular}{|c|c|c|c|}
\hline \multicolumn{4}{|c|}{ Cylindricity \% Change } \\
\hline & 8620 & 4320 & 8822 \\
\hline $500 / 2$ & 4.85 & 8.66 & 181.66 \\
\hline $500 / 4$ & 0.82 & 6.96 & 123.94 \\
\hline $550 / 2$ & 6.09 & 7.22 & 145.45 \\
\hline $550 / 4$ & 10.59 & 48.90 & 77.45 \\
\hline $580 / 1$ & 5.62 & 13.98 & 229.52 \\
\hline $580 / 2$ & 38.67 & 2.39 & 17.51 \\
\hline $580 / 4$ & 6.75 & 3.82 & 27.23 \\
\hline QT650 & 27.98 & 22.05 & 216.88 \\
\hline QT750 & 44.42 & 11.85 & 141.01 \\
\hline
\end{tabular}


Table 4.7b - Cylindricity Distortion

\begin{tabular}{|c|c|c|c|}
\hline \multicolumn{4}{|c|}{ Cylindricity Change (mm) } \\
\hline Condition & 8620 & 4320 & 8822 \\
\hline $500 / 2$ & 0.0019 & 0.0005 & 0.0277 \\
\hline $500 / 4$ & 0.0014 & 0.0049 & 0.0201 \\
\hline $550 / 2$ & 0.0014 & 0.0019 & 0.0254 \\
\hline $550 / 4$ & 0.0017 & 0.0057 & 0.0123 \\
\hline $580 / 1$ & 0.0015 & 0.0060 & 0.0341 \\
\hline $580 / 2$ & 0.0086 & 0.0036 & 0.0115 \\
\hline $580 / 4$ & 0.0041 & 0.0024 & 0.0131 \\
\hline QT650 & 0.0148 & 0.0117 & 0.0281 \\
\hline QT750 & 0.0171 & 0.0067 & 0.0277 \\
\hline
\end{tabular}

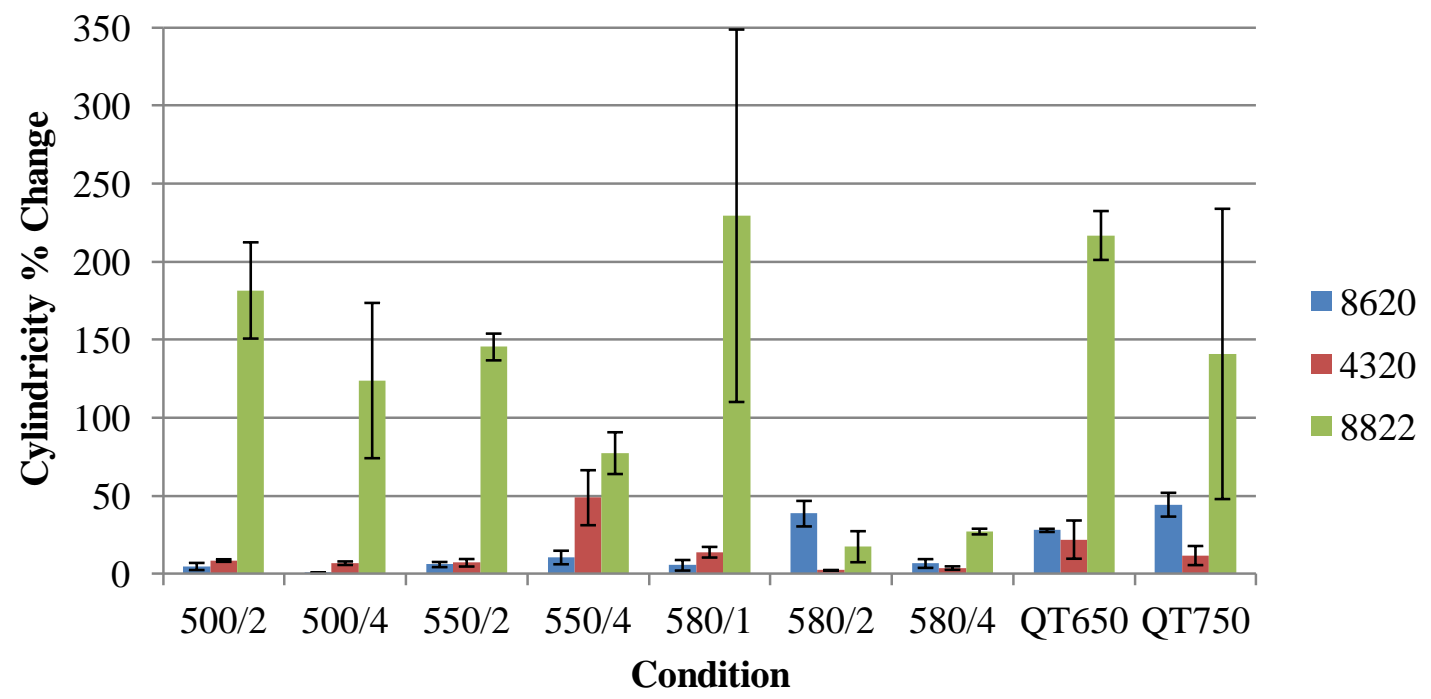

Figure 4.11: Cylindricity distortion.

Summary of Shape Distortion:

The primary shape distortion results can be summarized as follows. 1) For both the cylindricity and roundness measurements, the 8822 steel distortion values were considerably larger than the other materials for nearly all parameters. 8822 steel exhibits comparable or superior distortion characteristics for the flatness. Of note is that both cylindricity and roundness pertain to deviations on the inner and outer curved surfaces, in 
essence a hoop direction. The flatness measurements, where 8822 steel produced much less distortion, relates to an axial direction. 2) The quench-and-temper results exhibited significantly higher distortion values for flatness. The cylindricity and roundness values were in the mid-range of the austempered conditions.

\subsection{Residual Stress}

Surface residual stress measurement values are provided in Table 4.8; those values are presented in graphical form in Figure 4.12. Calibration results, as detailed in chapter 3, were in accordance with the acceptable limits put forth by ASTM Standard E915.

The direction of measurement (hoop or axial) did not significantly affect the magnitude of exhibited surface residual stress. The greatest magnitude change was $4 \mathrm{MPa}$ for the 580/1 austempered candidate. The austempered samples exhibited higher compressive residual stress than the quench and tempered samples. This is the expected result because the tempering process is designed to relax the residual stresses, which forum due to the transformation associated with the quenching process. 
Table 4.8 - Surface Residual Stress Results for 4320 Steel

\begin{tabular}{|c|c|c|}
\cline { 2 - 3 } \multicolumn{1}{c|}{} & \multicolumn{2}{c|}{ Surface Residual Stress (ksi) } \\
\cline { 2 - 3 } \multicolumn{1}{c|}{} & Hoop & Axial \\
\hline $500 / 2$ & $-73 \pm 0.9$ & $-75 \pm 0.4$ \\
\hline $500 / 4$ & $-86 \pm 0.9$ & $-86 \pm 0.4$ \\
\hline $550 / 2$ & $-64 \pm 0.7$ & $-67 \pm 0.6$ \\
\hline $550 / 4$ & $-81 \pm 0.6$ & $-83 \pm 0.5$ \\
\hline $580 / 1$ & $-84 \pm 0.9$ & $-80 \pm 0.3$ \\
\hline $580 / 2$ & $-85 \pm 0.9$ & $-85 \pm 0.5$ \\
\hline $580 / 4$ & $-72 \pm 0.9$ & $-71 \pm 0.3$ \\
\hline QT650/1 & $-44 \pm 0.9$ & $-47 \pm 0.5$ \\
\hline QT750/1 & $-59 \pm 0.6$ & $-60 \pm 0.4$ \\
\hline
\end{tabular}

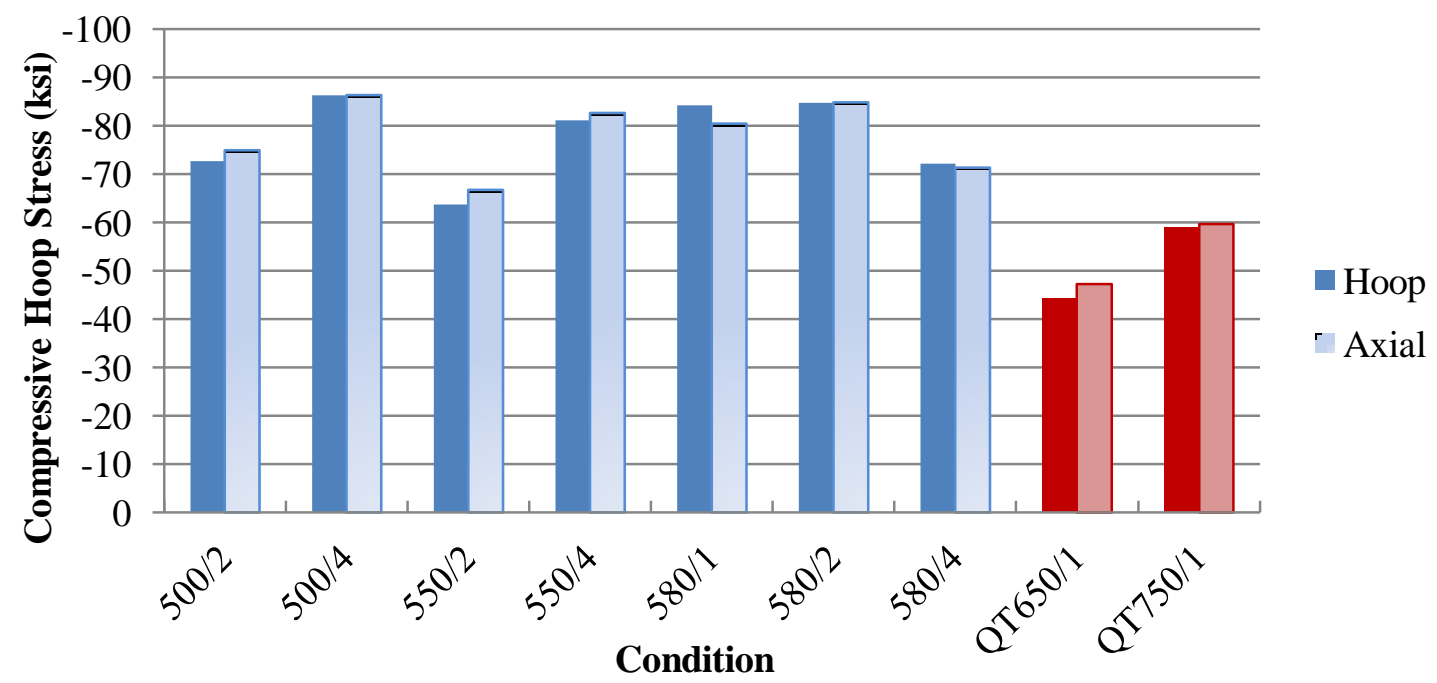

Figure 4.12: Surface residual stress for 4320 steel.

Figure 4.13 plots residual stress versus the outer diameter change. No significant trend is noted for the austempered samples, only that a higher surface compressive residual stress appears to be associated with smaller OD changes. This association would hold for most of the size distortion, and with flatness, where the austempered samples exhibited lower distortion. 


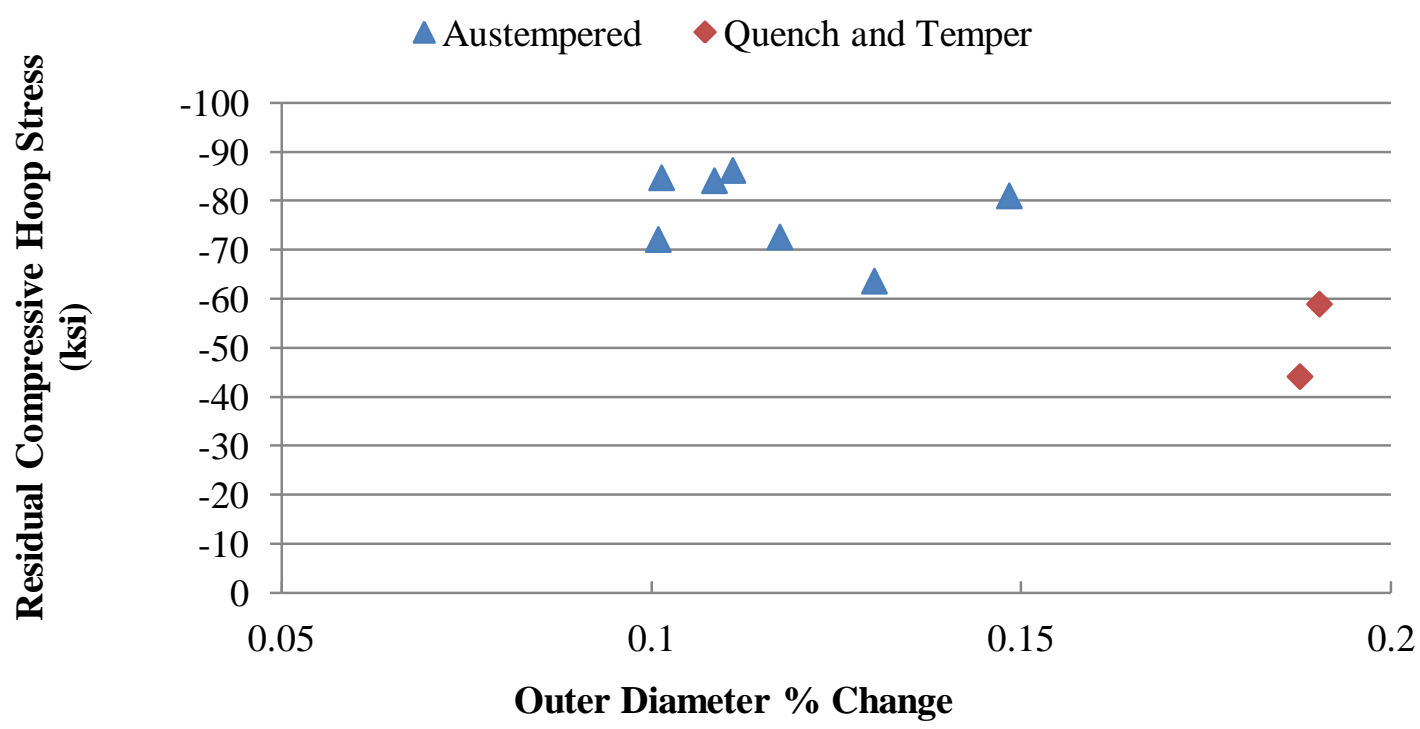

Figure 4.13: Surface residual stress and outer diameter distortion.

The data from residual stress depth profile measurements in one 4320 austempered sample, 500/4 and one QT750 4320 sample are provided in Table 4.9; and plots of residual stress vs depth can be seen in Figure 4.14a. The initial region is provided in greater detail in Figure 4.15b.

Table 4.9 - Residual Stress Depth Measurements for 4320 Steel

\begin{tabular}{|c|c|c|c|c|c|}
\hline \multicolumn{3}{|c|}{$500 / 4$} & \multicolumn{3}{c|}{ QT750 } \\
\hline $\begin{array}{c}\text { Depth } \\
\text { (inches) }\end{array}$ & Axial & Hoop & $\begin{array}{c}\text { Depth } \\
\text { (inches) }\end{array}$ & Axial & Hoop \\
\hline 0.0000 & $-74 \pm 0.7$ & $-76 \pm 0.8$ & 0.0000 & $-59 \pm 0.8$ & $-58 \pm 0.9$ \\
\hline 0.0006 & $-102 \pm 1.3$ & $-100 \pm 1.0$ & 0.0006 & $-53 \pm 1.2$ & $-52 \pm 0.9$ \\
\hline 0.0011 & $-116 \pm 1.4$ & $-118 \pm 1.3$ & 0.0012 & $-53 \pm 1.0$ & $-54 \pm 1.0$ \\
\hline 0.0030 & $-71 \pm 2.0$ & $-69 \pm 1.8$ & 0.0028 & $-30 \pm 1.0$ & $-29 \pm 0.8$ \\
\hline 0.0052 & $-50 \pm 1.9$ & $-49 \pm 1.5$ & 0.0048 & $-9 \pm 1.0$ & $-5 \pm 1.3$ \\
\hline 0.0103 & $-59 \pm 1.5$ & $-55 \pm 2.2$ & 0.0107 & $-2 \pm 1.2$ & $-3 \pm 0.9$ \\
\hline 0.0200 & $-52 \pm 1.4$ & $-51 \pm 2.2$ & 0.0235 & $-8 \pm 0.6$ & $-6 \pm 0.8$ \\
\hline 0.0454 & $+4 \pm 1.2$ & $-1 \pm 1.0$ & 0.0403 & $+4 \pm 1.2$ & $+3 \pm 1.0$ \\
\hline 0.0666 & $+22 \pm 1.1$ & $+24 \pm 0.8$ & 0.0686 & $+13 \pm 0.8$ & $+12 \pm 1.1$ \\
\hline 0.1016 & $+12 \pm 1.1$ & $+12 \pm 1.4$ & 0.0997 & $+6 \pm 0.9$ & $+4 \pm 1.5$ \\
\hline
\end{tabular}




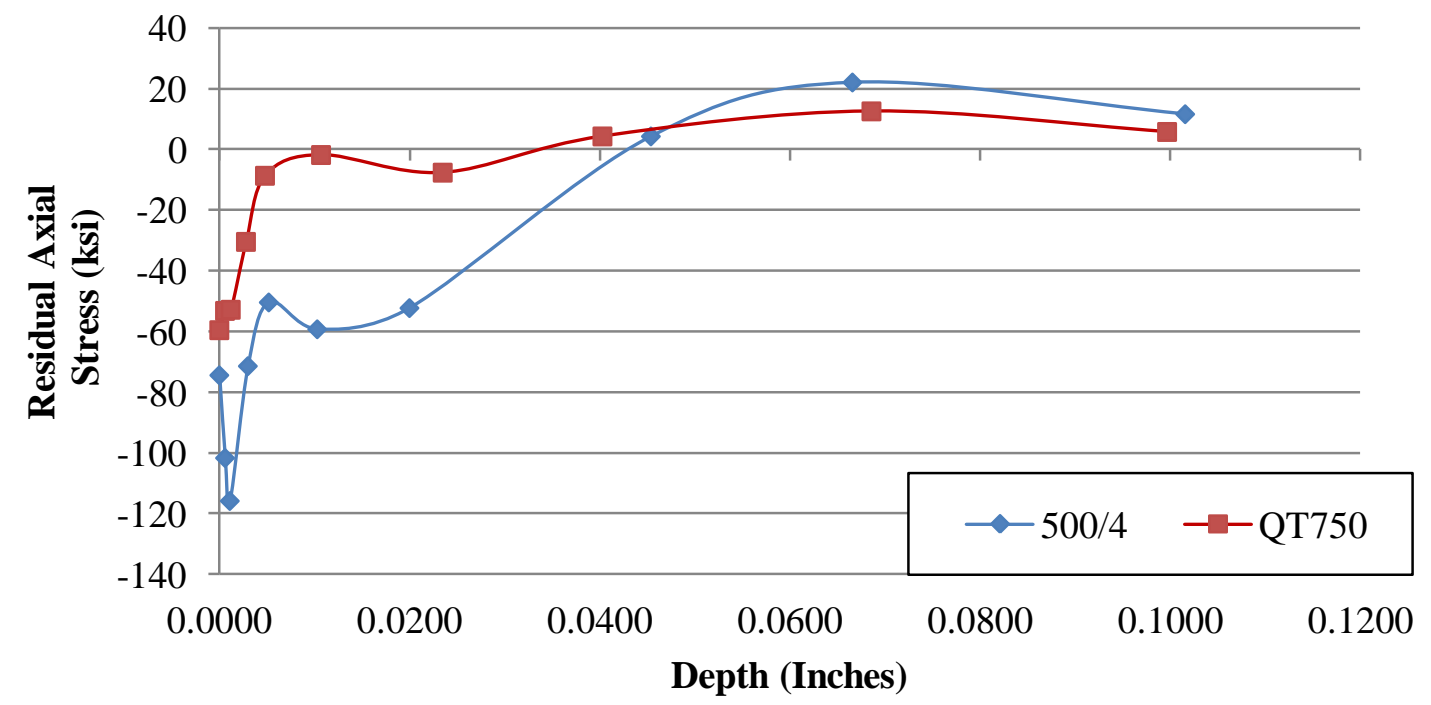

Figure 4.14a: Residual stress and depth for austempered and quench-and-tempered 4320 steel.

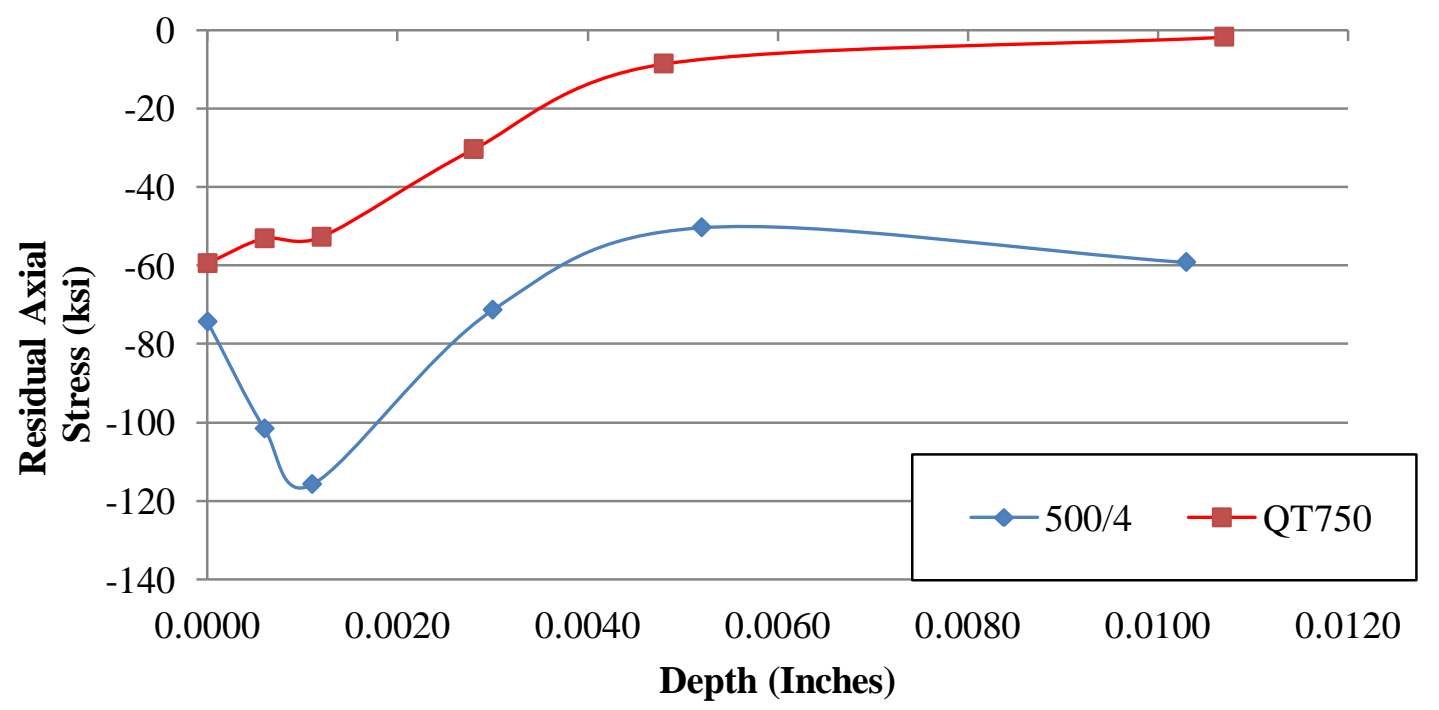

Figure 4.14b: Residual stress and depth for austempered and quench-and-tempered 4320 steel. 
Consistent with the work of other investigators [29, 39, 42], it was noted that both the austempered and quench-and-tempered conditions had compressive residual stress at the surface. However, differences were noted in the subsurface residual stress pattern. As noted in Figure 4.14a, quench-and-tempered sample decreased in its magnitude of compressive stress to nearly a non-stressed state at 0.012 inches. A small compressive region continued to about 0.3 inches, after which, it maintained a low tensile residual stress deeper into the material. The austempered sample increased its magnitude of compressive stress below the surface, reaching a peak of $116 \mathrm{ksi}$ of compressive stress, before stress levels dropped off to a magnitude of $50 \mathrm{ksi}$. Compressive residual stresses extended to 0.045 inches into the material, before becoming tensile.

Residual stress depth testing showed that the compressive region for the austempered condition extended deeper into the material than that of the quenched-andtempered condition. As well, the largest magnitude of compressive residual stress was larger for the austempered condition. Although the benefits of these characteristics have been laid out in the literature $[29,39,42]$, wear and fatigue testing should be carried out to correlate higher levels and deeper penetration of compressive residual stress to wear and fatigue life.

\subsection{Retained Austenite}

Retained austenite values are shown in Table 4.10, and are plotted on Figure 4.15. Retained austenite measurements showed that, for the quench and tempered sample, the retained austenite amounts were all below $1.5 \%$; the austempered sample peaked at $8 \%$. The retained austenite levels found in the quench-and-tempered condition can be 
explained by the high temperature tempering process, which allows for the decomposition of the retained austenite into bainite. The retained austenite peak found in the austempered sample is worth noting, primarily, any further decomposition of the retained austenite during service, could result in additional distortion. While additional testing would provide a more complete retained austenite profile, the general shape is identified. There was no correlation between the level of retained austenite found at a certain depth and the associated residual stress at that depth.

Table 4.10 - Retained Austenite Measurement

\begin{tabular}{|c|c|c|c|}
\hline \multicolumn{2}{|c|}{$500 / 4$} & \multicolumn{2}{c|}{ QT750 } \\
\hline $\begin{array}{c}\text { Depth } \\
\text { (inches) }\end{array}$ & $\begin{array}{c}\% \\
\text { Retained } \\
\text { Austenite }\end{array}$ & $\begin{array}{c}\text { Depth } \\
\text { (inches) }\end{array}$ & $\begin{array}{c}\% \\
\text { Retained } \\
\text { Austenite }\end{array}$ \\
\hline 0.0000 & $1.6 \pm 0.9$ & 0.0000 & $1.1 \pm 0.3$ \\
\hline 0.0011 & $1.9 \pm 0.3$ & 0.0012 & $1.4 \pm 0.9$ \\
\hline 0.0052 & $8.0 \pm 1.4$ & 0.0048 & $1.2 \pm 0.6$ \\
\hline 0.0103 & $2.0 \pm 0.4$ & 0.0107 & $0.8 \pm 0.5$ \\
\hline 0.0200 & $0.9 \pm 0.5$ & 0.0235 & $1.0 \pm 0.4$ \\
\hline 0.0666 & $1.0 \pm 0.2$ & 0.0686 & $1.0 \pm 0.4$ \\
\hline
\end{tabular}




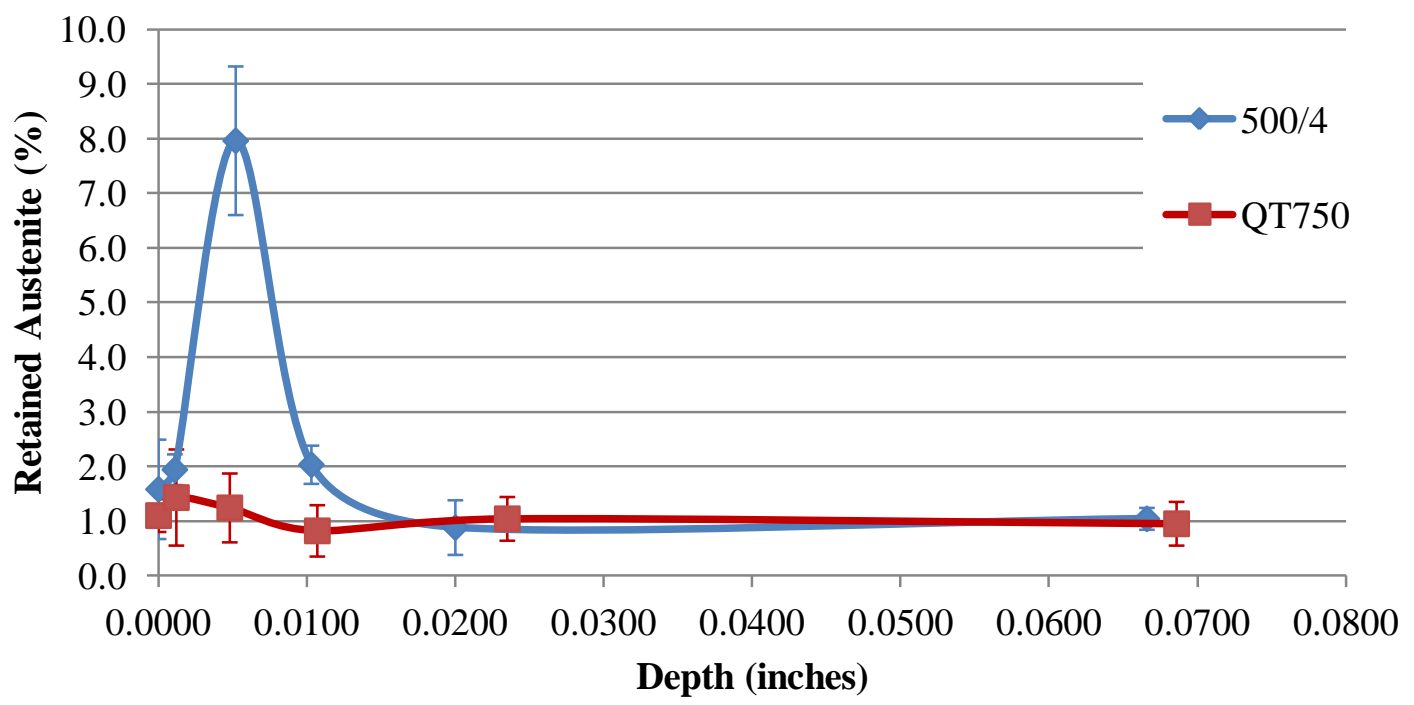

Figure 4.15: Retained austenite with depth.

\subsection{Mechanical Properties}

\subsubsection{Hardness}

Hardness measurements for core and case are shown in Tables 4.11 and 4.12, and Figures 4.16 and 4.17. Core hardness values were found to be fairly similar between the austempering process and the quench-and-tempering process. Across materials, the 8822 samples had higher hardness compared to the other materials. This is attributed to the higher carbon content of 8822 steel. 4320 steel tended to be harder than 8620 for the same condition. It was noted that with additional time and temperature there was a trend towards softer cores. This is explained in the austempered samples by the fact that with higher temperatures there is more energy available for diffusion and softening, while higher temperature allows for tempering of the martensite formed in the core crossing the $M_{S}$ line while quenching down to the austempering temperature. With the quench-and- 
tempered samples and the higher core hardness it is assumed that the elevated temperature is offset by the short amount of tempering time.

Table 4.11 - Core Hardness

\begin{tabular}{|c|c|c|c|}
\hline \multirow{2}{*}{ Parameter } & \multicolumn{3}{|c|}{ Material } \\
\cline { 2 - 4 } & 8620 & 4320 & 8822 \\
\hline $500 / 2$ & $31.2 \pm 0.4$ & $38.2 \pm 0.4$ & $43.2 \pm 0.6$ \\
\hline $500 / 4$ & $31.5 \pm 0.3$ & $38.4 \pm 0.1$ & $42.1 \pm 0.2$ \\
\hline $550 / 2$ & $33.9 \pm 0.5$ & $34.5 \pm 0.2$ & $42.9 \pm 0.3$ \\
\hline $550 / 4$ & $26.3 \pm 1.7$ & $34.8 \pm 0.2$ & $41.6 \pm 0.1$ \\
\hline $580 / 1$ & $29.7 \pm 0.3$ & $34.8 \pm 0.2$ & $36.6 \pm 0.2$ \\
\hline $580 / 2$ & $26.9 \pm 0.1$ & $33.4 \pm 0.6$ & $35.4 \pm 0.4$ \\
\hline $580 / 4$ & $27.3 \pm 0.2$ & $32.9 \pm 0.2$ & $36.6 \pm 0.2$ \\
\hline QT650/1 & $36.3 \pm 2.0$ & $41.6 \pm 0.9$ & $44.0 \pm 0.0$ \\
\hline QT750/1 & $39.8 \pm 0.2$ & $39.2 \pm 0.1$ & $42.4 \pm 0.2$ \\
\hline
\end{tabular}

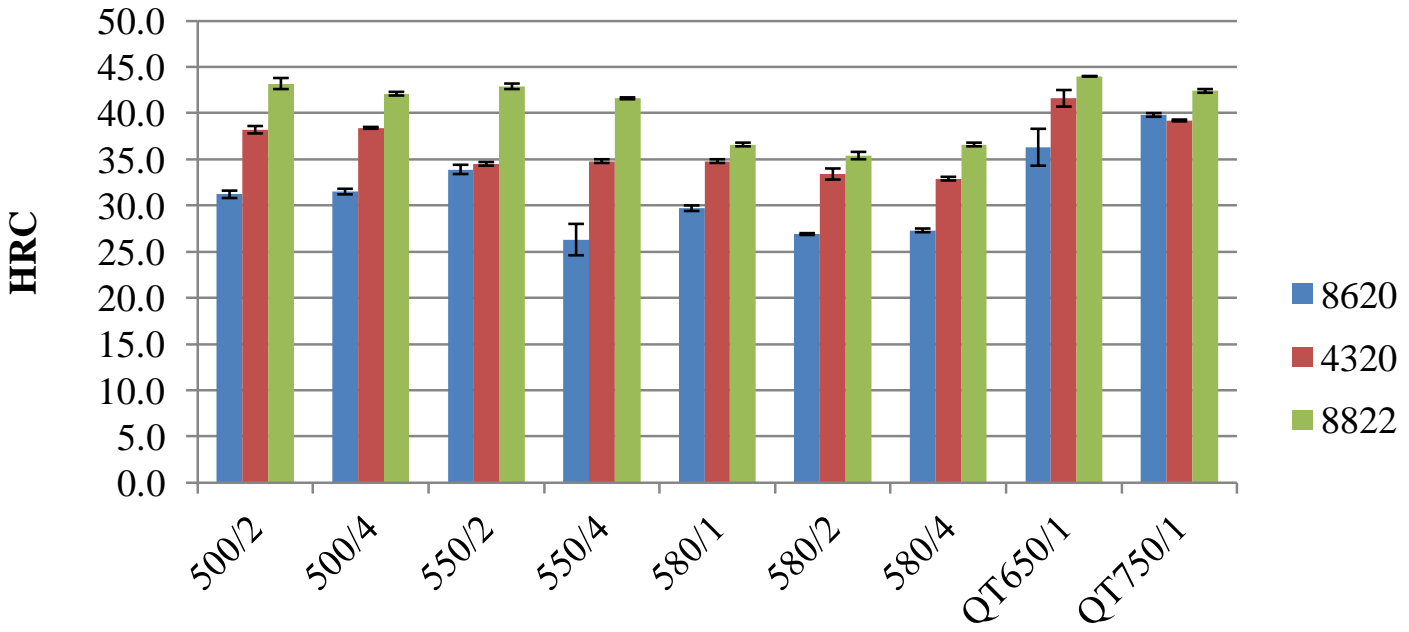

Condition

Figure 4.16: Core hardness. 
Table 4.12 - Case Hardness

\begin{tabular}{|c|c|c|c|}
\hline \multirow{2}{*}{ Parameter } & \multicolumn{3}{|c|}{ Material } \\
\cline { 2 - 4 } & 8620 & 4320 & 8822 \\
\hline $500 / 2$ & $58.1 \pm 0.2$ & $59.1 \pm 0.6$ & $59.1 \pm 0.1$ \\
\hline $500 / 4$ & $58.6 \pm 0.4$ & $59.0 \pm 0.9$ & $58.5 \pm 0.2$ \\
\hline $550 / 2$ & $58.2 \pm 0.4$ & $57.2 \pm 0.7$ & $57.7 \pm 0.2$ \\
\hline $550 / 4$ & $54.5 \pm 0.2$ & $55.0 \pm 0.1$ & $57.8 \pm 0.3$ \\
\hline $580 / 1$ & $54.2 \pm 0.1$ & $53.5 \pm 0.1$ & $54.8 \pm 0.6$ \\
\hline $580 / 2$ & $52.9 \pm 0.4$ & $52.6 \pm 0.3$ & $54.7 \pm 0.2$ \\
\hline $580 / 4$ & $54.4 \pm 0.1$ & $53.1 \pm 0.2$ & $54.2 \pm 0.3$ \\
\hline QT650 & $55.7 \pm 0.1$ & $55.2 \pm 0.4$ & $56.0 \pm 0.1$ \\
\hline QT750 & $52.4 \pm 0.1$ & $51.0 \pm 0.1$ & $53.1 \pm 0.1$ \\
\hline
\end{tabular}

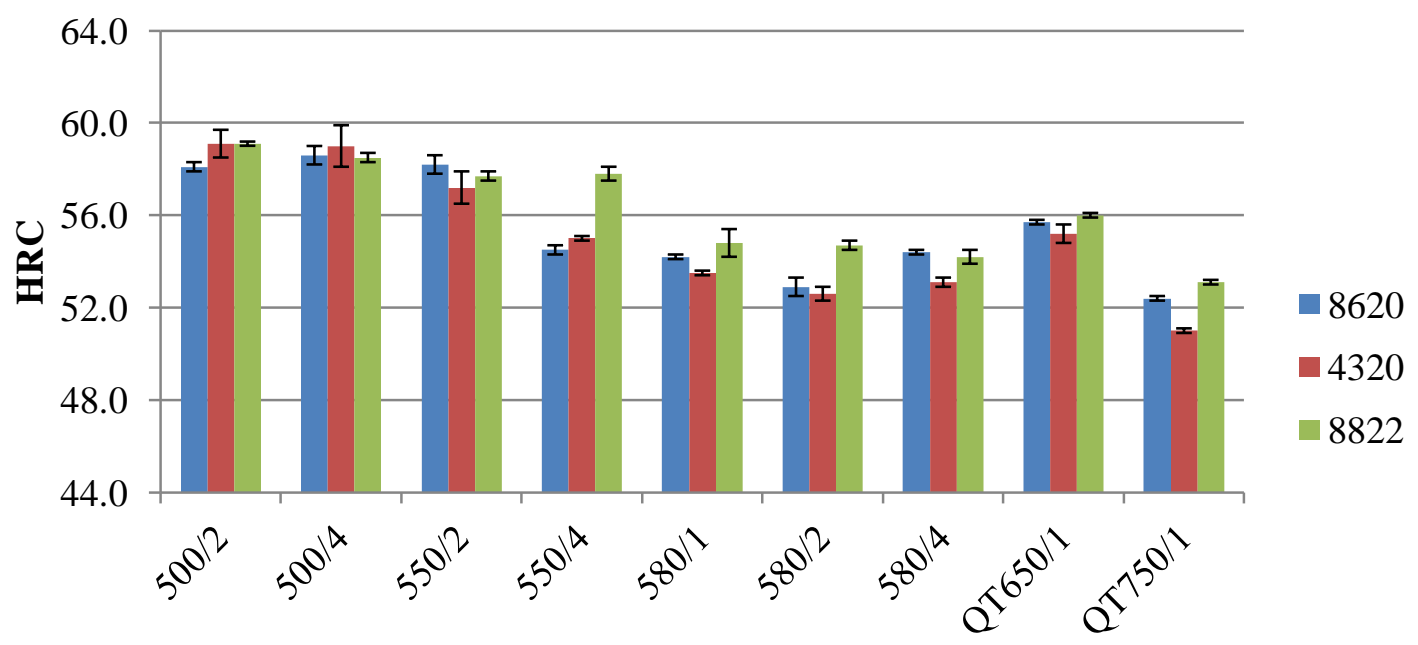

Condition

Figure 4.17: Case hardness.

When comparing the case hardness values, it is first most evident that the case hardnesses are much higher than those associated with the core. This is expected with the case hardening process because of the additional carbon content at the surface. Similar to the core hardness measurements, it was noted that with increased time and temperature combinations the hardness values decreased. There was not a large difference between materials in terms of case hardness. All of the samples were carburized at the same 
carbon potential, and thusly have the same carbon content. The differences in hardness in the austempered conditions can be associated in part to the type of bainite formed during austempering. As mentioned, upper bainite is a softer microstructure than that of lower bainite. Since the bainite formation at $500{ }^{\circ} \mathrm{F}$ will be closer to lower bainite, and thusly, martensite, it will have a higher hardness. The quench-and-temper samples exhibit the same pattern, where higher temperature results in a lower hardness. This is due to the higher temperature allowing for more softening of the material.

\subsubsection{Toughness}

Charpy impact toughness values are shown in Table 4.13. Averages of three samples are presented for all conditions, along with standard deviation. Full data sets were not available for all samples. The samples which were quench-and-tempered at 350 ${ }^{\circ} \mathrm{F}$ only had 2 samples prepared for each material. Impact values are compared in Figure 4.18.

Table 4.13a - Charpy Impact Toughness for 8620 Steel

\begin{tabular}{|c|c|c|c|c|c|}
\hline Material & Parameter & 1 & 2 & 3 & Average (ft-lbs) \\
\hline \multirow{5}{*}{8620} & $500 / 2$ & 4.07 & 4.59 & 4.44 & $4.37 \pm 0.27$ \\
\cline { 2 - 6 } & $500 / 4$ & 4.18 & 3.90 & 4.23 & $4.10 \pm 0.18$ \\
\cline { 2 - 6 } & $550 / 2$ & 2.57 & 2.53 & 3.21 & $2.77 \pm 0.38$ \\
\cline { 2 - 6 } & $550 / 4$ & 5.68 & 6.19 & 6.70 & $6.19 \pm 0.51$ \\
\cline { 2 - 6 } & $580 / 1$ & 8.69 & 7.33 & 7.50 & $7.84 \pm 0.74$ \\
\cline { 2 - 6 } & $580 / 2$ & 8.33 & 7.00 & 6.97 & $7.43 \pm 0.78$ \\
\cline { 2 - 6 } & $580 / 4$ & - & - & - & 9.30 \\
\cline { 2 - 6 } & QT350 & 5.92 & 5.81 & - & $5.87 \pm 0.04$ \\
\cline { 2 - 6 } & QT650 & 2.93 & 2.81 & 2.49 & $2.74 \pm 0.23$ \\
\cline { 2 - 6 } & QT750 & 7.06 & 8.55 & 7.25 & $7.62 \pm 0.81$ \\
\hline
\end{tabular}


Table 4.13b - Charpy Impact Toughness for 8822 Steel

\begin{tabular}{|c|c|c|c|c|c|}
\hline Material & Parameter & 1 & 2 & 3 & Average (ft-lbs) \\
\hline \multirow{5}{*}{} & $500 / 2$ & 2.33 & 2.52 & 2.37 & $2.41 \pm 0.10$ \\
\cline { 2 - 6 } & $500 / 4$ & 2.41 & 2.21 & 1.95 & $2.19 \pm 0.23$ \\
\cline { 2 - 6 } & $550 / 2$ & 2.42 & 2.27 & 2.25 & $2.31 \pm 0.09$ \\
\cline { 2 - 6 } & $550 / 4$ & 2.22 & 2.24 & 2.20 & $2.22 \pm 0.02$ \\
\cline { 2 - 6 } & $580 / 1$ & 3.58 & 3.06 & 2.90 & $3.18 \pm 0.36$ \\
\cline { 2 - 6 } & $580 / 2$ & 3.56 & 3.43 & 2.96 & $3.32 \pm 0.32$ \\
\cline { 2 - 6 } & $580 / 4$ & - & - & - & 2.68 \\
\cline { 2 - 6 } & QT350 & 1.96 & 2.27 & - & $2.12 \pm 0.11$ \\
\cline { 2 - 6 } & QT650 & 1.79 & 1.82 & 1.79 & $1.80 \pm 0.02$ \\
\cline { 2 - 6 } & QT750 & 2.35 & 2.43 & 2.34 & $2.37 \pm 0.05$ \\
\hline
\end{tabular}

Table 4.13c - Charpy Impact Toughness for 4320 Steel

\begin{tabular}{|c|c|c|c|c|c|}
\hline Material & Parameter & 1 & 2 & 3 & Average $(\mathrm{ft}-\mathrm{lbs})$ \\
\hline \multirow{7}{*}{} & $500 / 2$ & 11.43 & 12.52 & 12.12 & $12.02 \pm 0.55$ \\
\cline { 2 - 6 } & $500 / 4$ & 11.98 & 11.46 & 11.81 & $11.75 \pm 0.27$ \\
\cline { 2 - 6 } & $550 / 2$ & 7.94 & 9.93 & 8.54 & $8.80 \pm 1.02$ \\
\cline { 2 - 6 } & $550 / 4$ & 10.37 & 11.65 & 12.91 & $11.64 \pm 1.27$ \\
\cline { 2 - 6 } & $580 / 1$ & 7.56 & 5.94 & 8.31 & $7.27 \pm 1.21$ \\
\cline { 2 - 6 } & $580 / 2$ & 11.60 & 10.65 & 11.18 & $11.14 \pm 0.48$ \\
\cline { 2 - 6 } & $580 / 4$ & - & - & - & 11.82 \\
\cline { 2 - 6 } & QT350 & 11.48 & 10.45 & - & $10.97 \pm 0.36$ \\
\cline { 2 - 6 } & QT650 & 11.62 & 10.87 & 12.80 & $11.76 \pm 0.97$ \\
\cline { 2 - 6 } & QT750 & 19.95 & 21.58 & 20.75 & $20.76 \pm 0.82$ \\
\hline
\end{tabular}




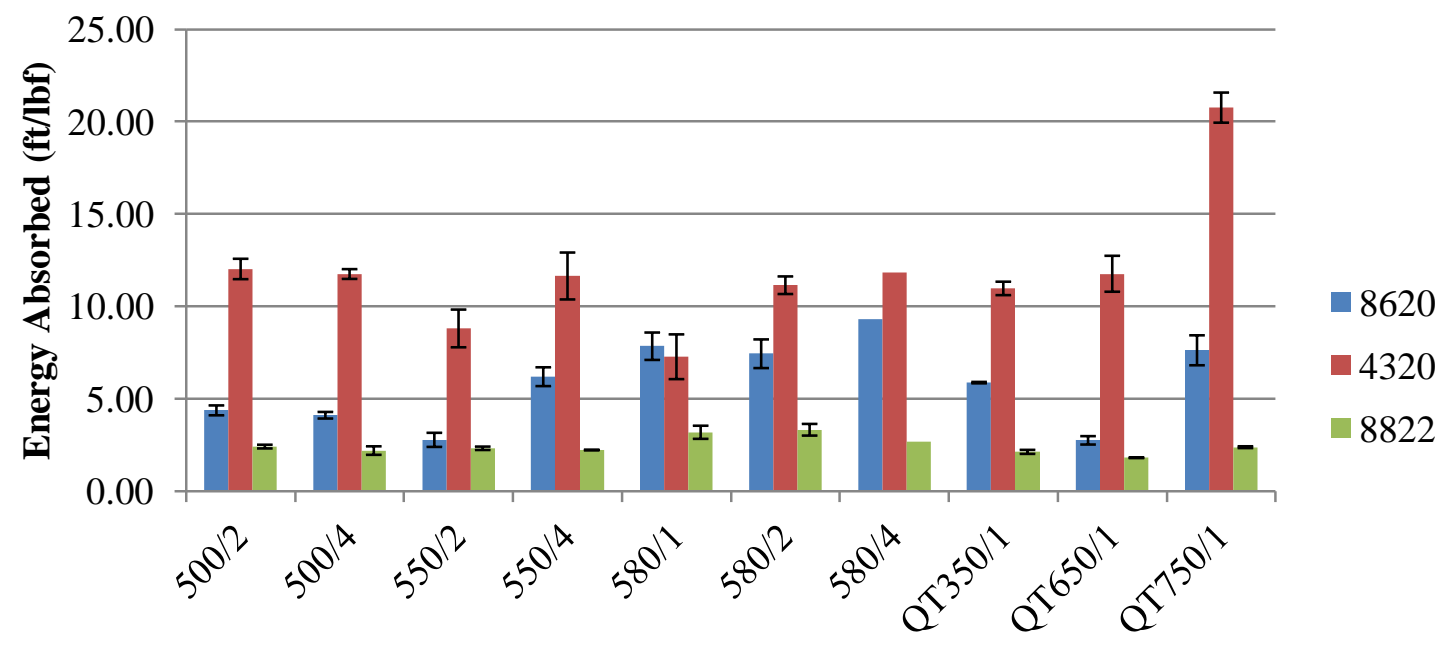

Condition

Figure 4.18: Charpy toughness results.

Austempering time and temperature did not seem to have an effect on the impact toughness of the three steels. As previously noted, toughness is primarily indicative of the low-carbon content core microstructure, the $M_{S}$ temperature of which is well above the austempering temperature, and therefore not as affected by time as the case microstructures. The 4320 samples which were quench-and-tempered at $750{ }^{\circ} \mathrm{F}$ showed considerably more Charpy toughness than the rest of the samples which were tested. This highest tempering temperature allows for a softening of the core microstructure.

When the austempered results were compared to those of the $350^{\circ} \mathrm{F}$ temper it was found that austempering was generally able to provide toughness similar to the currently used process. A comparison of the materials showed that the 4320 steels gave the highest results for impact toughness overall across all of its austempering and quench-andtempering temperatures, which is expected due to its increased nickel content. 8822 steel 
was not able to achieve any toughness value greater than $3.3 \mathrm{ft} / \mathrm{lbs} .8620$ had the widest spread of values within the austempered condition, 2.7 to $9.3 \mathrm{ft}-\mathrm{lbs}$.

Fracture surfaces were examined for selected samples to examine the fracture mode. Samples were selected based on having high and low impact toughness, as well as to represent the three materials. Images are shown in Figure 4.19.
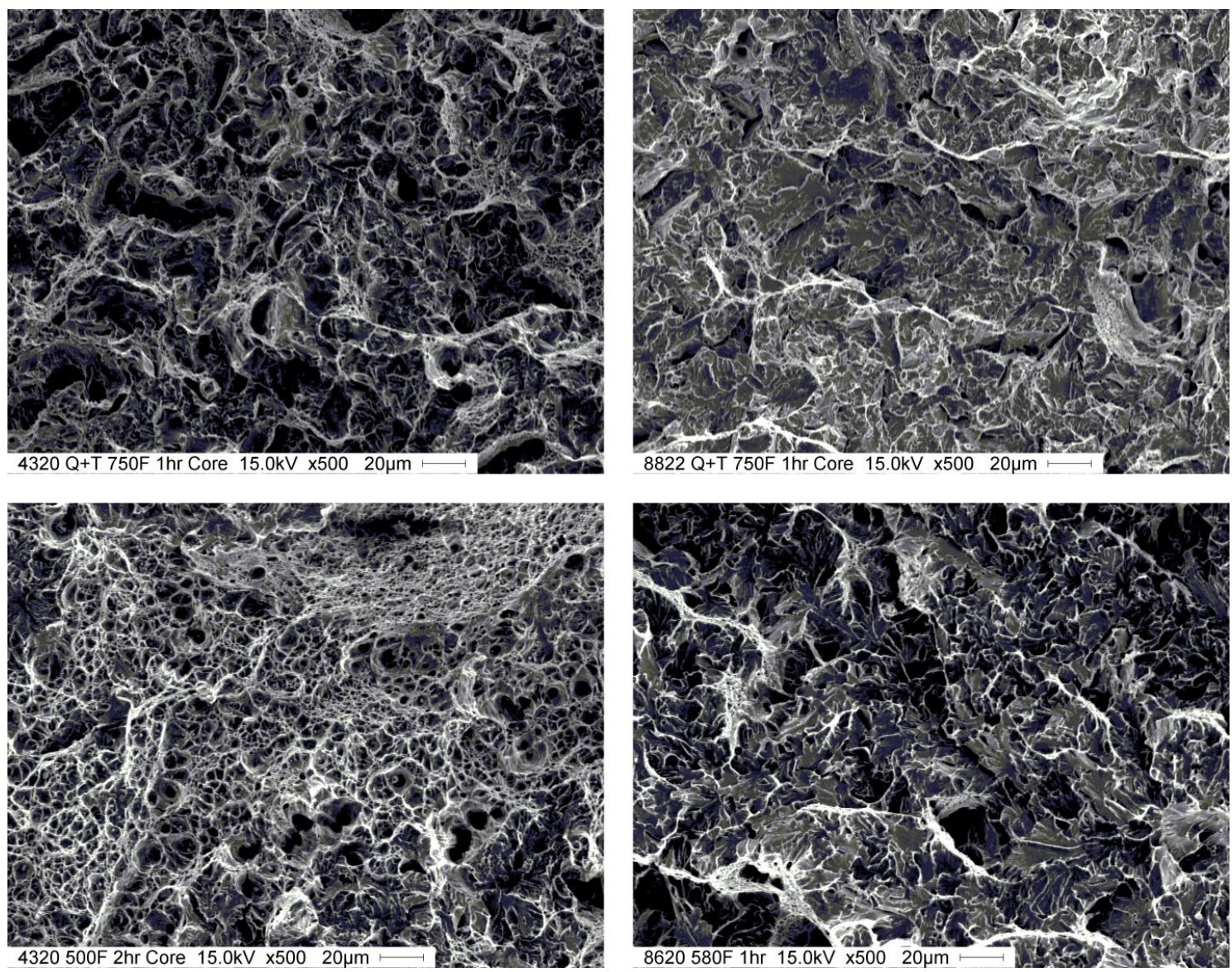

Figure 4.19: SEM fracture surface images.

Fracture surfaces for 4320 steel showed a majority of ductile fracture, while 8620 and 8822 steel had mostly brittle and mixed modes of fracture. This correlates with the general expectation that lower impact toughness samples trend towards brittle rather than ductile. 


\subsection{Economic Discussion}

Comparable or improved mechanical and distortion properties are not by themselves sufficient to proceed with the substitution of the austempering process for the traditional quench-and-temper process. As has been noted, assessment of the tribological behaviour of the austempered carburized case is a vital factor for components subject to friction and wear. Additionally, the economics of the substitution must be considered. A primary benefit of the austempering process is its low distortion, which may remove the manufacturing step associated with distortion correction for the quench-and-temper process. The time, machining, and materials handling costs associated with distortion correction need to be compared to the increased time and energy costs associated with the austempering thermal process.

The microstructure, mechanical properties, and distortion results of this study indicate that the austempering process shows improvement over the traditional quenchand-temper process for carburized steel components. A particularly strong argument can be made for the 4320 steel to continue on to the next logical step of wear testing. The 8620 steel shows improvement in many areas for austempering compared to the quenchand-temper process. The argument is perhaps not as strong for the 8822 material. However, each material has a specific purpose with respect to carburizing: 4320 for toughness with its nickel content; 8822 for higher hardness with its increased carbon content; 8620 for general purpose carburizing. Should wear testing reveal comparable or improved behaviour, the following and final step would be a full economic analysis. 


\section{CONCLUSIONS AND RECOMMENDATIONS FOR FUTURE WORK}

The effects of austempering were compared to those of quench-and-tempering when applied to a carburized low alloy steel. Three materials were tested, SAE 8620, 8822, and 4320 steel. Samples were carburized, then either austempered or quench-andtempered. Microstructures were observed for all conditions. Distortion due to the carburizing and heat treatment process was measured. Residual stress and retained austenite levels were measured for 4320 steel samples. Core and case hardness, as well as toughness were determined.

\subsection{Conclusions}

The following conclusions were drawn based on the results of the experiment.

1. Austempering produced bainite in the case of carburized samples. With increased time it was possible to form a greater percentage of bainite. Higher temperatures resulted in the formation of more feathery upper bainite, while lower temperatures resulted in more acicular, needle-like bainite. For the same temperature, 8822 tended to form lower bainite, while 4320 and 8620 would form upper bainite. Incomplete transformations led to retained austenite and martensite being found in the case. The case microstructure for all quench-and-tempered samples was tempered martensite.

2. Core microstructures revealed martensite in the core of all samples. For the austempered samples the low carbon content of the core, relative to the case, resulted in the $M_{S}$ temperature being high enough that martensite transformation 
occurred during the quench to the austempering temperature. For the quench-andtempered samples, the martensite core was subsequently tempered.

3. Size distortion was generally lower for austempered samples than quench-andtempered samples. 4320 showed less distortion across most of the size distortions (ID, OD, gap width) than 8620 and 8822 . Austempering produced similar or better distortion characteristics than quench-and-tempering.

4. Austempering produced less shape distortion than quench and tempering, although the differences were not significant. Roundness distortion was reduced with increasing austempering time. 8822 steel exhibited large shape distortions, and would require more correction than the other two materials.

5. Compressive surface residual stress was found in all tested Navy C-rings. Austempered samples produced higher compressive residual stress than those which had been quench-and-tempered. The tempering process allowed for the relaxation of the residual stresses formed during the initial quenching process. Residual stresses in the axial and longitudinal were with 4 ksi of each other.

6. Residual stress depth profiles revealed that the compressive layer in the austempered material extended to a greater depth than that of the quench-andtempered material. Austempering peaked at a compressive residual stress of -118 ksi in the hoop direction at a depth of 0.0011 inches, while the quench-andtempered sample had its highest compressive stress at the surface. The quenchand-tempered sample had near-neutral stress found around 0.01 inches subsurface, before a slight increase in compressive stress. Tensile stresses were found deeper 0.04 inches and deeper. The austempered sample maintained 
complete compressive stress until 0.04 inches into the material before tensile stress became present.

7. Retained austenite was present in greater amounts in the austempered sample; however, at depths greater than 0.02 inches the retained austenite levels were similar. Decomposition of retained austenite during tempering led to the lower retained austenite levels in the quench-and-tempered sample.

8. Case hardness decreased with increased times and temperatures. The highest case hardness was noted for the lowest austempering temperatures. Core hardness was higher for quench-and-tempered samples for both 8620 and 4320 steel, and similar for 8822 .

9. 4320 steel was considerably tougher than the other materials, and is designed to be such. For all steels, austempering produced a sample with toughness similar to the $350{ }^{\circ} \mathrm{F}$ tempered samples. Although the $750{ }^{\circ} \mathrm{F}$ temper for 4320 steel produced a high toughness relative to all the other conditions for all materials, it is neither commonly used in production, nor is it under consideration for use. For this study, the $750{ }^{\circ} \mathrm{F}$ temper was used as an upper limit of tempering.

\subsection{Summary of Conclusions}

The conclusions drawn from this study support the potential for austempering to replace quench-and-tempering as a method of heat treating carburized low-alloy steels. Austempering was able to reduce shape distortion, and limit size distortion for three lowalloy steels, while maintaining mechanical properties similar to the currently used process. Of some concern is the retained austenite level in the case of the austempered conditions, as it can decompose and result in further distortion during service. Residual 
stress values indicate that wear and fatigue properties could be improved with austempering; actual wear and fatigue testing test data is currently lacking.

\subsection{Recommendations for Future Work}

Recommendations are provided below for further testing to determine the potential for austempering to replace the quench-and-tempering process for carburized steels. Suggestions for improving the accuracy of test results are also provided.

1. Larger samples populations are recommended for distortion testing. In this study only two Navy C-rings were produced for each condition, led to a large statistical variation in certain cases. Additional samples for each condition would help to give a more definite value for expected distortion from heat treatment.

2. X-Ray diffraction should be performed on additional C-ring samples. The increased sample size would limit the effects of localized peaks in stress and retained austenite in individual specimens on the results. It is also recommended that additional measurements be taken during depth testing to develop a more complete profile of residual stress and retained austenite levels.

3. Carbon content depth profiles and case depth measurements would be useful to relate to residual stress and retained austenite depth profiles, as well as microstructural observations.

4. Production of quench-and-tempered C-rings tempered at $350{ }^{\circ} \mathrm{F}$ for one hour would allow a full comparison between the current process and the austempering heat treatment for distortion, residual stress, and retained austenite. 
5. A more quantitative comparison of the economics of producing austempered parts and quench-and-tempered parts should be performed. The differences in production time, material selection, and equipment running costs should be included. It will provide a more complete picture than just a physical properties comparison

6. Wear and fatigue testing should be performed to further compare the austempering and quench-and-tempering processes. Wear and fatigue testing would allow for prediction of the in-service life of austempered parts compared to quench-and-tempered ones.

7. A comparison of austempering to austempering-and-tempering would allow the measurement of the effect of tempering the untempered martensite formed in the core resulting from austempering alone. In particular, toughness would be expected to increase.

\subsection{Unique Contribution of the Work}

The unique contribution of this study to the field was a quantitative examination of the effects of austempering and quench-and-tempering on carburized low alloy steels. Previous literature, while extolling the benefits of austempering as a heat treatment for carburized parts $[5,9,35,56]$, had not made quantitative comparisons of distortion and residual stress characteristics of the heat treatment processes. This study generated quantitative measurements of distortion and residual stress for both the austempering and quench-and-tempering processes. 


\section{REFERENCES}

1. Engineering Properties of Steel. Edited by Philip D. Harvey. Metals Park, Ohio: American Society For Metals, 1982

2. Smith, William F. Structure and Properties of Engineering Alloys. McGraw-Hill Inc., 1993

3. "Fe-C Phase Diagram - The Basis of the Heat Treatment of Steel" Retrieved 10 January, 2013, from http://www.mrl.ucsb.edu/ edkramer/LectureVGsMat100B/99Lecture14VGs/FeC PhaseDiagramVG.html.

4. Callister Jr., William D. Fundamentals of Materials Science and Engineering / An Interactive e-Text. New York: John Wiley \& Sons, Inc, 2001.

5. Krauss, G. Steels: Heat Treatment and Processing Principles. Metals Park, Ohio; ASM International, 1990.

6. Nishiyama, Zenji. Martensitic Transformation. New York: Academic Press, Inc, 1978.

7. Capdevila, C., F. G. Caballero, and Garcia De Andres. "Analysis of Effect of Alloying Elements on Martensite Start Temperature of Steels." Materials Science and Technology 19, no. 5 (2003): 581-586.

8. Liu, C., Z. Zhao, D. O. Northwood, and Y. Liu. "A New Empirical Formula for the Calculation of Ms Temperatures in Pure Iron and Super-Low Carbon Alloy Steels." Elsevier Science BV, P.O. Box 211, Amsterdam, 1000 AE, Netherlands, 2001.

9. Andrews, K.W., "Empirical Formulae for the calculation of some transformation temperatures" Journal of the Iron and Steel Institute, Vol. 203, 1965, p 721-727.

10. Krauss, G. Principles of Heat Treatment of Steel. Metals Park, Ohio; American Society for Metals, 1980. 
11. Herring, Daniel H. "Understanding the Benefits of Austempering." Industrial Heating 72, no. 12 (2005): 10,12.

12. Zhao, Z., X. Guan, C. Wan, C. Liu, and D. O. Northwood. "A Re-Examination of the B Sub 0 and B Sub s Temperatures of Steel." Materials and Design (UK) 21, no. 3 (2000): 207-209.

13. Zhao, Z., C. Liu, Y. Liu, and D. O. Northwood. "A New Empirical Formula for the Bainite Upper Temperature Limit of Steel." Journal of Materials Science (USA) 36, no. 20 (2001): 5045-5056.

14. Caballero, Francisca G., Maria Jesus Santofimia, Carlos Garcia-Mateo, and Carlos Garcia De Andres. "Time-Temperature-Transformation Diagram within the Bainitic Temperature Range in a Medium Carbon Steel." Materials Transactions 45, no. 12 (2004): 3272-3281.

15. Lee, J. S., B. H. Song, H. G. Sung, S. Y. Kim, and B. Y. Hur. "The Effect of Isothermal Heat Treatment on the Rolling Contact Fatigue of Carburized Low Carbon Microalloyed Steel." Materials Science Forum 544-545, (2007): 151-154.

16. Clark, Donald S., and Varney, Wilbur R., Metallurgy for Engineers. New York, NY: D. Van Nostrand Company, 1962.

17. Otto, F. J. and D. H. Herring. 2002. "Gear Heat Treatment Part I" Heat Treating Progress (USA) 2 (5): 27-31.

18. J.R. Davis, Surface Engineering of Carbon and Alloy Steels, Surface Engineering, Vol. 5, ASM Handbook, ASM International, 1994, p 701-740

19. Guide to practical boost-diffuse carburizing. Industrial Heating 60, no. 1 (1993): 36-37.

20. Réti, T., "Residual Stresses in Carburized, Carbonitrided, and Case-Hardened Components," Handbook of Residual Stress and Deformation of Steel. G. Totten, M. Howes, T. Inoue (Editors), ASM International, Materials Park, OH., 2002. 189-208. 
21. Child, H. C.; Still, Dr. F. "Boost/diffuse carburizing," Heat Treatment of Metals 3 , no. 2 (1976): 39

22. Pye, David. "Low-Pressure Carburizing." Industrial Heating 76, no. 4 (2009): 8282.

23. Larsson, M., B. Jansson, R. Blom, and A. Melander. "Influence of Austenitizing and Quenching Temperature on Jominy Hardenability of a Case Hardening and a Boron Steel." Scand.J.Metall. 19, no. 2 (1990): 51-63.

24. Davis, J.R., editor. Surface Hardening of Steels Understanding the Basics. Materials Park, Ohio: ASM International, 2002

25. Tartaglia, John M.; Hayrynen, Kathy L. "A Comparison of Fatigue Properties of Austempered Versus Quenched and Tempered 4340 Steel," Journal of Materials Engineering and Performance 21 (2012): 1008-1024.

26. Leslie, William C. The Physical Metallurgy of Steels. Marietta, Ohio: Hemisphere Publishing Corporation, 1981.

27. Keough, John R. Austempered Materials and their Applications to Drive Line and Suspension Components, 2000.

28. Keough, W. R. Equipment, Process and Properties of Modern Austempering, edited by Keough, W. R. 1994.

29. Keough, W.R. "Carbo-Austempering." Carburizing and Nitriding With Atmospheres; Cleveland, Ohio; USA; 6-8 Dec. 1995(1995) 135-142.

30. Hart, B. J. "Austempering Offers Precision, Consistency, in Steel Quenching." Heat Treat. 15, no. 10 (1983): 36-38.

31. Boyle, Erin, Randy Bowers, and Derek O. Northwood. "The use of Navy C-ring Specimens to Investigate the Effects of Initial Microstructure and Heat Treatment on the Residual Stress, Retained Austenite, and Distortion of Carburized Automotive Steels." SAE Transactions: Journal of Materials \& Manufacturing 116, (2008): 253-261. 
32. Otto, F. J. and D. H. Herring. "Gear Heat Treatment Part II." Heat Treating Progress (USA) 2, no. 5 (2002): 27-31.

33. Suliteanu, M. "Minimizing Gear Distortion During Heat Treatment," Gear Technology 13, no. 2 (1996): 15-19

34. Demerest, W. L. "Hardening of Industrial Saw Blades without Distortion." Industrial Heating 48, no. 7 (1981): 14-15.

35. Northwood, Derek O., Lily He, Erin Boyle, and Randy Bowers. 2007. "Retained Austenite - Residual Stress - Distortion Relationships in Carburized SAE 8620 Steel." Materials Science Forum 539-543: 4464-4469.

36. Hernandez-Morales, B., O. Barba-Mendez, A. Ingalls-Cruz, and J. BarreraGodinez. "Mathematical Modelling of Temperature and Stress Evolution during Cooling of a Stainless Steel Navy C-ring Probe." International Journal of Materials and Product Technology 24, no. 1-4 (2005): 306-318.

37. Gestwa, Wojciech and Malgorzata Przylecka. "The Modification of Sodium Polyacrylate Water Solution Cooling Properties by AL2O3." Advances in Materials Science and Engineering 2010, (2010).

38. Campagna, Victoria, Randy Bowers, Derek O. Northwood, Xichen Sun, and Peter Bauerle. "Distortion and Residual Stresses in Nitrocarburized and Carbonitrided SAE 1010 Plain Carbon Steel." SAE International Journal of Materials \& Manufacturing 1, no. 1 (2009): 690-696.

39. Grum, J. "Overview of residual stress after quenching part II: factors affecting quench residual stresses," International Journal of Materials and Product Technology 24, nos. 1-4 (2005): 53-97.

40. Pineault, J.A., Belassel, M., and Brauss, M.E., X-Ray Diffraction Residual Stress Measurement in Failure Analysis, Failure Analysis and Prevention, Vol. 11, ASM Metals Handbook, ASM International, 2002, p 484-497

41. Ebert, L. J. 1978. "The Role of Residual Stresses in the Mechanical Performance of Case Carburized Steels." Metall.Trans.A 9A (11): 1537-1551. 
42. Ahn, S. G., T. W. Kim, S. C. Jung, and Y. W. Kim. "The Effect of Tempering on Mechanical and Fatigue Properties in Gas-Carburized Cr-Mo Gear Steel." SAE Transactions: Journal of Materials \& Manufacturing (USA) 106, no. 5 (1997): 671-678.

43. Hildenwall, B. and T. Ericsson. "Residual Stresses in the Soft Pearlite Layer of Carburized Steel." J.Heat Treat. 1, no. 3 (1980): 3-13.

44. Hua, Jiang, Domenico Umbrello, and Rajiv Shivpuri. "Investigation of Cutting Conditions and Cutting Edge Preparations for Enhanced Compressive Subsurface Residual Stress in the Hard Turning of Bearing Steel." Journal of Materials Processing Technology 171, no. 2 (2006): 180-187.

45. Lohe, D., K-H Lang, and O. Vohringer. Residual Stresses and Fatigue Behavior, Handbook of Residual Stress and Deformation of Steel, ASM International, 2002, p $27-53$

46. Parrish, Geoffrey, The Influence of Microstructure on the Properties of CaseHardened Components. Materials Park, Ohio: American Society for Metals, 1980.

47. Skalli, N. and J. F. Flavenot. "Prise En Compte des Contraintes Résiduelles Dans un Calcul Prévisionnel de Tenue en Fatigue." CETIM Inf. no. 90 (1985): 35-47.

48. Suffredini, R. L. "Factors Influencing Austempering." Heat Treating. 12, no. 1 (1980): 14-16, 18-19.

49. Ren, W., K. Li, and Y-L, Lee. 2004. "Optical Measurement of Residual Stress at the Deep-Rolled Crankshaft Fillet." SAE Technical Papers.

50. ASTM Standard E915-10, 2010, "Standard Test Method for Verifying the Alignment of X-Ray Diffraction Instrumentation for Residual Stress Measurement" ASTM International, West Conshohocken, PA, 2010, DOI: 10.1520/E0915-10, www.astm.org

51. Kovacs, T. Principles of X-Ray Metallurgy. ILIFFE Books Ltd: London, 1969.

52. "Basic X-Ray Powder Diffraction.” Accessed 31 May 2013. http://xray.tamu.edu/pdf/notes/intro2xrd.pdf 
53. Pineault, J., M. Belassel, M. Brauss, and J. Ladouceur. "Mapping Residual Stress Gradients in Automotive Components Via X-Ray Diffraction." SAE Transactions: Journal of Materials \& Manufacturing 116, (2008): 249-252.

54. Sue, J. A. and G. S. Schajer. Stress Determination for Coatings, ASM International, Materials Park, OH 44073-0002, USA, 1994.

55. Ruud, C. Measurement of Residual Stresses, Handbook of Residual Stress and Deformation of Steel, ASM International, 2002, p 100-117

56. Jatczak, C. F. "Retained Austenite and its Measurement by X-Ray Diffraction." Society of Automotive Engineers, Pp.20, 1980 (1980)

57. Convert, F., Miege, B. “Doser Rapidement l'Austénite Résiduelle Avec Précision." Journal de Physique IV. No. 6 (1996): 863-878.

58. Arnell, R. D., K. A. Ridal, and J. Durnin. "Determination of Retained Austenite in Steel by X- Ray Diffraction." J IRON STEEL INST 206, no. 10 (1968): 10351036.

59. Richman, R. H. and R. W. Landgraf. "Some Effects of Retained Austenite on the Fatigue Resistance of Carburized Steel." Metallurgical Transactions A 6A, no. 5 (1975): 955-964.

60. ASTM Standard E18-12, 2012, "Standard Test Methods for Rockwell Hardness of Metallic Materials," ASTM International, West Conshohocken, PA, 2012, DOI: 10.1520/E0018-12, www.astm.org.

61. ASTM Standard E23-12c, 2012, "Standard Test Methods for Notched Bar Impact Testing of Metallic Materials," ASTM International, West Conshohocken, PA, 2012, DOI: 10.1520/E0023-12C, www.astm.org.

62. Lyman, Taylor, editor. Metals Handbook Ninth Edition Volume 1 Properties and Selection: Irons and Steels. Metals Park, Ohio: American Society for Metals, 1978. 


\section{PUBLICATIONS AND PRESENTATIONS}

\section{Publications}

1. Clark, A. D., D. O. Northwood, R. J. Bowers, X. Sun, and P. Bauerle.

"Comparison of Austempering and Quench-and-Tempering Processes for Carburized Automotive Steels." SAE International Journal of Materials and Manufacturing 6 (2) (2013): 146-153.

\section{Presentations}

1. Clark, A. D., D. O. Northwood, R. J. Bowers, X. Sun, and P. Bauerle.

"Comparison of Austempering and Quench-and-Tempering Processes for Carburized Automotive Steels." SAE 2013 World Congress, Detroit, MI, U.S.A., 16-18 April, 2013. 


\section{VITA AUCTORIS}

NAME:

PLACE OF BIRTH:

DATE OF BIRTH:

EDUCATION:
Andrew David Clark

Toronto, Ontario

December 20, 1989

Ontario Secondary School Diploma

Thornhill Secondary School

Thornhill, Ontario

2007

Bachelor of Applied Science

Honours Mechanical Engineering with Materials Option University of Windsor

Windsor, Ontario

2011

Master of Applied Science

Engineering Materials

University of Windsor

2013 